Andrews University

Digital Commons @ Andrews University

1977

\title{
An Evaluation of Selected Seventh-day Adventist Sermons in Taiwan in the Light of Criteria for Biblical Teaching
}

John Chun-Ming Lu

Andrews University

Follow this and additional works at: https://digitalcommons.andrews.edu/dmin

Part of the Practical Theology Commons

\section{Recommended Citation}

Lu, John Chun-Ming, "An Evaluation of Selected Seventh-day Adventist Sermons in Taiwan in the Light of Criteria for Biblical Teaching" (1977). Professional Dissertations DMin. 629.

https://dx.doi.org/10.32597/dmin/626

https://digitalcommons.andrews.edu/dmin/629

This Project Report is brought to you for free and open access by the Graduate Research at Digital Commons @ Andrews University. It has been accepted for inclusion in Professional Dissertations DMin by an authorized administrator of Digital Commons @ Andrews University. For more information, please contact repository@andrews.edu. 

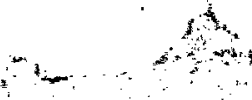

Andrews University

Seventh-day Adventist Theological Seminary

AN EVALUATION OF SELECIED SEVENTH-DAY ADVENTIST

SERMONS IN TAIWAN IN THE LIGHT OF CRITERIA

FOR BIBLICAL PREACHING

A Project Report

Presented in Partial Fulfillment

of the Requirements for the Degree

Doctor of Ministry

by

John Chun-Ming Lu

January 1977 



\section{AN EVALUATION OF SELECTED SEVENTH-DAY ADVENTIST \\ SERMONS IN TAIWAN IN THE LIGHT OF CRITERIA \\ FOR BIBLICAL PREACHING}

\section{A project presented}

in partial fulfillment of the requirements

for the degree

Doctor of Ministry

by

John Chun-Ming Lu

APPROVAL BY THE COMMITTEE

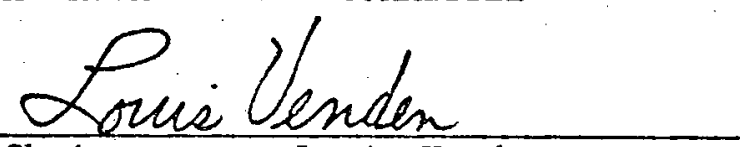

Chairperson: Louis Venden

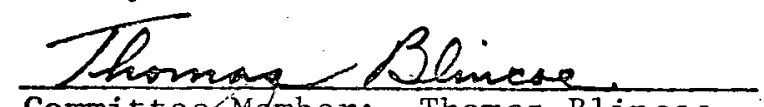

Committee Mémber: Thomas Blincoe
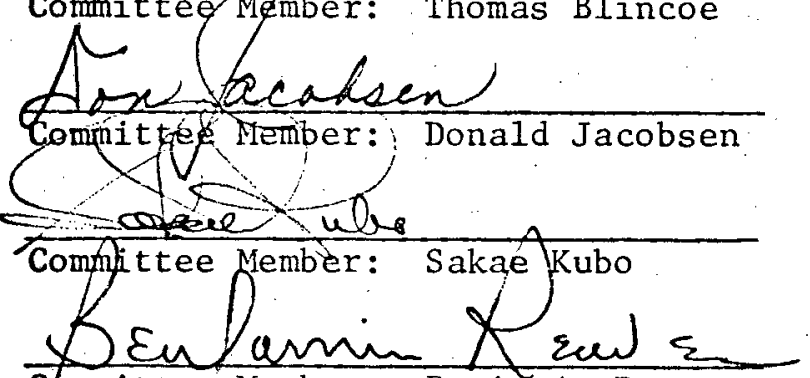

committee Member: Benjamin Reaves
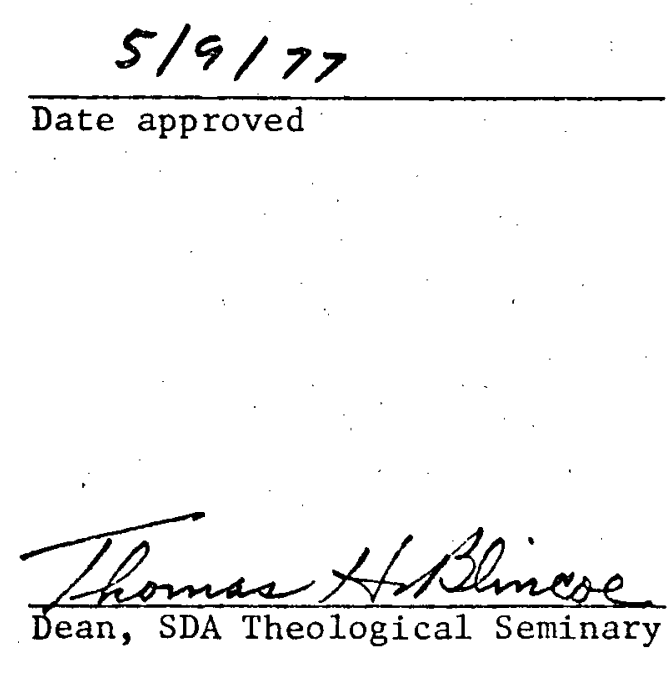
TABLE OF CONTENTS

ACKNOWLEDGEMENT . . . . . . . . . . . . . . . . .

Task

Objectives and Goals . . . . . . . . . . . . . .

Method and Organization of the Study ...........

Limitations of this Study. . . . . . . . . . . . . . .

Biblical Quotations... . . . . . . . . . . . . .

Chapter

I. A VIEW OF THE NATURE AND PURPOSE OF PREACHING . . . .

The Bible Commands and Calls for Preaching . . . . 5

The Crisis of Preaching. . . . . . . . . . . . 7

A Vital Theology of Preaching Needed . . . . . . 8

The Meaning of "Preaching" in the New Testament. . . 9

What It Means to Preach. . . . . . . . . . . . . 11

Proclaiming Gospel Truth . . . . . . . . . 11

Interpreting Gospel Truth . . . . . . . . . 18

God Confronting Man .. . . . . . . . . . 23

II. THE BIBLE AND ITS PLACE IN PREACHING . . . . . . . . . 30

Why Preaching from the Bible? . . . . . . . . 30

The Uniqueness of the Bible . . . . . . . . . . 31

Jesus' Example ................. 33

God's Word and Human Needs . . . . . . . . 35

What Is Biblical Preaching? . . . . . . . . . . 38

Preaching from the Word of God . . . . . . . . 40

Preaching in the Power of the Spirit . . . . . . 46

Preaching with Persuasive Skil1... . . . . . 49

The Values of Biblical Preaching . . . . . . . 56

III. AN ANALYTICAL STUDY OF ADVENTIST PREACHING

IN TAIWAN ................... . . . 60

Sermon 1 ........................ . . . 64

Sermon 2 .................... 67

Sermon 3................................ 70

Sermon 4 ................. . . . . 73

Sermon 5....................... 76 
TABIE OF CONTENTS (Continued)

Chapter

III. (Continued)

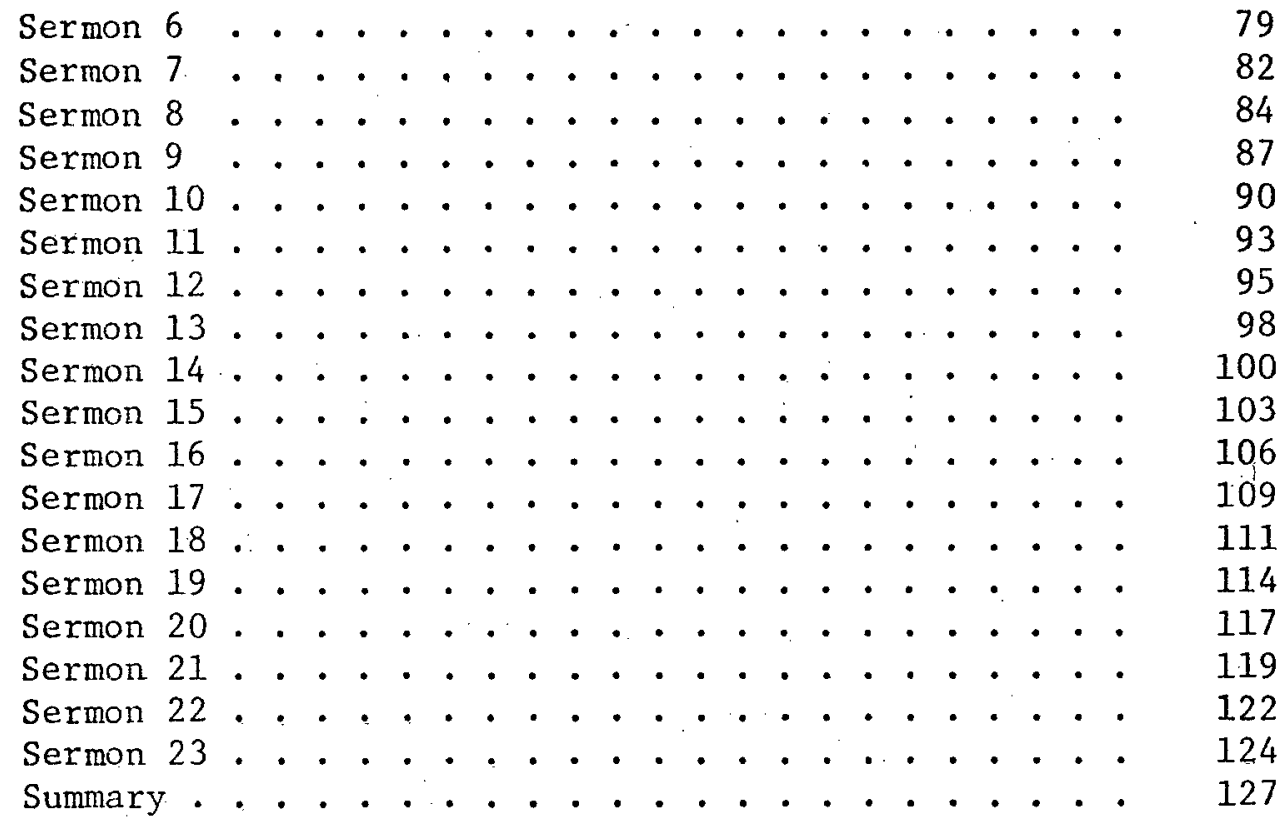

IV. SYLLABUS . . . . . . . . . . . . . . . . 134

Introduction . . . . . . . . . . . . . 134

V. OVERALL EVALUATTON AND CONCLUSIONS . . . . . . . . 137

Summary . . . . . . . . . . . . . . 137

Conclusions . . . . . . . . . . . . . . 140

A Personal Stimulation and Growth Experience . . . 142

APPENDICES . . . . . . . . . . . . . . . . . . 146

A. A Sample Pre-Project Sermon . . . . . . . . . 147

B. A Sample Post-Project Sermon . . . . . . . . . . . 158

C. A Portion of a Homiletics Syllabus . . . . . . . . 168

BIBLIOGRAPHY . . . . . . . . . . . . . . . . 202 


\section{ACKNOWLEDGEMENT}

Many persons have helped to refine and improve the theme treated in this project, as the footnotes will indicate. Besides these, I am especially grateful to Louis Venden, my project supervisor, associate professor of Preaching at Andrews University, who has inspired and encouraged this important study. He patiently and tirelessly guided my work, spending much time in stimulating discussions. He carefully read the manuscripts and offered wise counse1, thus improving the content of this project. His keen observation related to this work and his many valuable suggestions have contributed much to the completion of this project.

Special thanks are due to my project supervisory committee, Drs. Thomas Blincoe and Donald Jacobsen for their fine cooperation and willingness to spend much time reading and giving their helpful suggestions.

To Dr. Arnold Kurtz, I express my sincere thanks for his timely encouragement and untiring counsel and guidance.

In addition, I am indebted to my faithful fellow preachers in Taiwan who have shown their interest in this project by supplying the needed sermon tapes. 


\section{INTRODUCTION}

Biblical preaching is the divine standard for Christian preachers, and should be the constant aim of every one of them. Unto this they have been called, and for this they have been set apart by God and men. For this their congregations hunger, and upon this God's favor graciously rests. By precept, example and influence the Bible writers join the Apostle Paul in the exhortation, "Preach the Word" (II Ti 4:2).1

It is the writer's firm conviction that the Bible is the greatest book for the preacher and the only source for relevant preaching. The word of Deut. 8:3: ". . man shall not live by bread alone, but by every word that proceeds from the mouth of God," reminds us that man does not adequately provide for his life by means of merely satisfying his bodily need; he must also open his heart to the Word of God which is God's revelation of Himself and of His will to men.

In this confused age, one of the most pressing needs of Adventist churches in Taiwan is that the Word of God be heard. The people of God need to be nurtured with the Word of God and it is the responsibility of the Adventist ministers to preach the Word in such a way that they feed the flock.

It was the privilege of the writer to attend a Seventh-day Adventist ministers' conference some years ago in Taiwan. One morning, following the hour of morning devotion, a group of church

\section{$1_{F}$. D. Whitese11, The Art of Biblical Preaching (Grand} Rapids: Zondervan Publishing House, 1950), p. 15. 
pastors were discussing the message they had heard. They were impressed by the way in which the message of the devotion, based on Paul's letter to Philemon, was presented. At the end of that informal discussion a pastor who had been in the ministry for over seven years expressed his heartfelt desire when he said, "I wish that some one could teach us how to really preach from the Bible. - ." Since then this need has become a burden for the writer. The Doctor of Ministry program at Andrews University has challenged him to dig deeper into this subject of preaching from the Bible. In the class "Word and Worship," he has been constantly reminded of an intimate bond which unites preaching to the sacred Scriptures.

\section{Task}

The project's first task is to gain a view of the nature and purpose of preaching with special emphasis on the relationship of the Bible to preaching. Then it proceeds to survey-Seventh-day Adventist preaching in Taiwan with respect to its strengths and weaknesses. And, finally, it makes an attempt to design materials for the teaching of preaching in Taiwan, keeping in mind the expressed needs and special situations confronted there.

\section{Objectives and Goals}

This project has been prepared with the definite objective of advancing the final proclamation of the gospel of Jesus Christ. With this in mind, the writer hopes that this project will: 
1. Enable him to gain a personal insight into his own weaknesses in preaching and to facilitate personal growth in competence as a preacher.

2. Increase his competence in developing a training program that will meet the needs of the field.

3. Develop and strengthen the preaching ability of the ministerial students of the Taiwan Adventist College.

\section{Method and Organization of the Study}

Chapter I is a theoretical study of a view of the nature and purpose of preaching based on an examination of the Bible and some current literature related to the subject.

Chapter II deals with a special emphasis on the place of the Bible in the sermon. It stresses that the pulpit is a place where the pure word of God and not the messages or concepts of men is to be preached. An attempt is made to answer questions such as: Why preach from the Bible? What is meant by Biblical preaching? What are the advantages of preaching from the Bible?

Chapter III is an endeavor to understand the preaching situation of the Seventh-day Adventist Church in Taiwan. In order to understand the Adventist preaching situation in Taiwan and its needs, a collection of twenty-two recorded sermons has been made. It is a current sampling of sermons preached in the local churches at the time of the regular Sabbath worship service by seventeen ministers in Taiwan. A careful analysis of the twenty-two sermons is made to determine how each sermon is related to the Bible, and how it adapts to the actual congregation and occasion. 
Chapter IV introduces part of a syllabus on preaching which grew out of this study and which will be used in teaching a homiletics course at Taiwan Adventist College. The five lessons presented from the syllabus are related to biblical preaching.

Chapter $\mathrm{V}$ attempts to give an overall summary and some general conclusions based on the entire study.

One of the taped sermons (no. 23) that was analyzed is completely translated into English for the reader's convenience in Appendix A. In Appendix B the writer presents another sermon in which he seeks to demonstrate the principles emphasized in the study.

\section{Limitations of this Study}

It must not be denied that this study has definite limitations. No attempt is made here to deal with preaching along all of the formal lines of concern, but rather to review the imperative for preaching with a view of the nature and purpose of preaching, and how to use the Bible in preaching.

Only twenty-two sermons from Taiwan have been studied. They are tape-recorded sermons. The writer was not present in the actual preaching situations, however, he is acquainted with the congregations to whom the sermons were preached and has, himself, preached in these churches.

\section{Biblica1 Quotations}

A11 Biblical quotations are from the Revised Standard Version. 
CHAPTER I

A VIEN OF THE NATURE AND PURPOSE OF PREACHING

The Bible Commands and Calls for Preaching

When Jesus came into Galilee, He came preaching. Before He did miracles, He was a preacher. Luke reports, "He went on through cities and villages, preaching and bringing the good news of the kingdom of God" (Lk 8:1). "When He called the twelve together and gave them power and authority over all demons and to cure diseases, He sent them out to preach the kingdom of God and to heal. - and they went through the towns, preaching the gospel, and healing everywhere" ( $\operatorname{lk} 9: 1,2,6)$. After the resurrection Jesus announced that the gospel "should be preached in his name among all nations. . ." (Lk 24:47). His aposties were to make disciples of all men by preaching the good news to all nations.

On the day of Pentecost, the disciples were made preachers as the Spirit came in power upon them. Peter faced the multitude of Jerusalem and preached Christ. The first experience of the church after the coming of the Holy Spirit at Pentecost was hearing a sermon. The early Christians marched forward on their mission, going "everywhere preaching the word" (Acts 8:4). The book of Acts illustrates the place of preaching in the beginning of Christianity. The motivation for so much preaching was explained to Cornelius by Peter:

"He commanded us to preach to the people. ." (Acts 10:42). 
Preaching was to be thejx first duty and nost important work. They understood the reason for their assignment: "It pleased God through the folly of what we preach to save those who believe" (1 Cor 1:21). The preaching of the gospel today is still the obligation of His church, and preaching should certainly be one of the main concerns of a gospel minister. Believers are assured in Rom 10:9-17 that it is the God-ordained means of spreading the gospel.

The book of Acts has shown that preaching is closely related to the church. They "preach the word" (Acts 8:4, 25; 15:35); "preach the gospel" (Acts 8:25; 16:10); "preach Jesus Christ" (Acts $5: 42 ; 8: 5 ; 9: 20 ; 11: 20)$; and "preach the kingdom of God" (Acts 28:31). No wonder Paul lists preaching the word of God as the supreme commission to the church when, in 1 Cor 12 , he 1 ists the spiritual gifts for the cominon good. From these Bible records one can safely say that the Bible commands and calls for preaching. Other than these New Testament records which show the importance of preaching, the long history of the Christian church bears ample witness to the truth that;

Whenever the church has, been most loyal to its commission and to its Lord, it has put preaching in the forefront of its program. The glorious epochs of evangelical awakening and spiritual advance have been those in which the pulpit has been honoured and the word of God has been sounded out without fear and without compromise. On the other hand, the decline of gospel preaching has consistently been accompanied by the decline of vital Christianity. 1

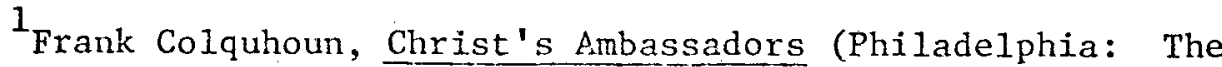
Westminster Press, 1965), pp. 16-17. The story of the English Church in the sixteenth century during the Dark Ages, and during the Reformation are good illustrations of this. Also see A History of Preaching, Vo1. 1, by Edwin C. Dargan (Grand Rapids: Baker Book House, 1954), pp. 12-22. 
All this serves to emphasize not only the important place, but also the primary place, of preaching in relation to Christianity.

\section{The Crisis of Preaching}

It is a sad truth that the pulpit today is one of the weakest spots in the life of the church. Preaching should be powerful, but often it is not. In recent years many preachers have failed to interest or to chalienge their hearers. Their preaching is generally irrelevant and gives 1ittle help for the problems of modern life. Their sermons lack in sincerity, are too abstract and unrea1, and are mainly moralistic in character. Therefore, the value of preaching is often questioned, and many doubt whether preaching is effective in this scientific age.

James Montgomery Boice says:

If preaching really is outmoded, as many of its detractors affirm, then current opinion should not trouble the preachers of the gospel; ministers should surrender their preaching ministry and take up some other worthwhile pursuits. But if this is not true--if preaching is still the primary means under God's grace by which men and women are won to faith in Jesus Christ and are built up into the fullness of Christ's stature-then the current trends should trouble them and they should look diligently for the causes of the decline in good preaching and for a cure. 1

The suggestion that "people are not interested in listening to preaching anymore" is not an adequate excuse for neglecting Christ's command to proclaim the gospel. Jesus assured His followers that:

"This gospel of the kingdom will be preached throughout the whole world, . . and then the end wiil come" (Mt 24:14). His ministers

${ }^{1}$ James Montgomery Boice, "The Great Need for Great Preaching," Christianity Today, Dec. 20, 1974, p. 7. 
are to preach the gospel until He returns. John the Revelator writes: "I saw another angel flying in midheaven, with an eternal gospel to proclaim to those who dwell on earth. . ." (Rev 14:6). This is the commission for believers today.

Emil Brunner made a daring claim when he said:

Where there is true preaching, where, in the obedience of faith, the word is proclaimed, there, in spite of all appearances to the contrary, the most important thing that ever happens upon this earth takes place.1

If this is true, preaching is a very significant experience today, even as it was in New Testament times.

\section{A Vital Theology of Preaching Needed}

The basic cause for the present condition of preaching must be a lack of a vital theology of preaching. If pastors had worthier views of the nature and function of preaching, the weaknesses of many sermons heard today would be overcome. It is true that the place of preaching has declined. This ought not to discourage ministers to give up preaching, but rather it should challenge them to look into its weaknesses and to improve its quality. Over thirty years ago, Herbert H. Farmer wrote that if one were asked to indicate briefly the most distinctive and central trends in contemporary Christian theology, the answer would be "the rediscovery of the significance of preaching. " 2 Not only then, but also in recent

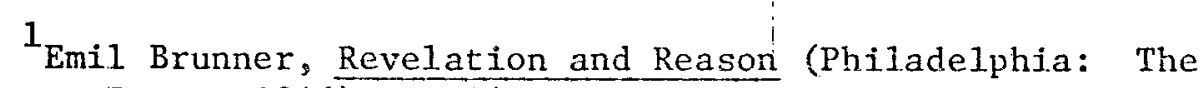
Westminster Press, 1946), p. 142.

2 Herbert Farmer, The Servant of the Word (New York: Charles Scribner's Sons, 1942), p. 9 . 
years there has been a definite attempt to show the true importance and the nature of preaching.

\section{The Meaning of "Preaching" in the New T'estament}

There are seven Greek words each translated as "preaching" in the New Testament. They are as follows:

\section{Euaggelizō ( $\left.\dot{v}^{\prime} \alpha \gamma \gamma \varepsilon \lambda \hat{\zeta} \zeta \omega\right)$ originally meant to announce the} glad tidings of the Messiah, of the kingdom of God, or of eternal. salvation offered through Christ. Later it came to mean the good news itself, or good news preached, as in Acts $8: 12$. Here, preaching is the act of announcing the good news of Jesus Christ and His kingdom. 1

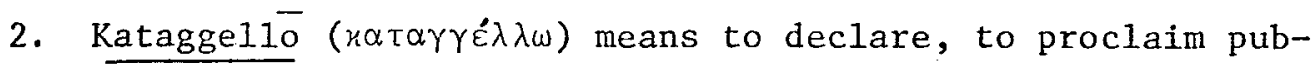
licly, with the included idea of commending. It is translated "preach" in the King James Version and "proclaim" in the Revised Standard Version. Acts $4: 1,2$ is an example of the use of this word. It means to tell thoroughly and to proclaim with authority, as one does who is commissioned to spread official news to other persons. Here preaching can be seen as a proclamation of the Word of God with authority.

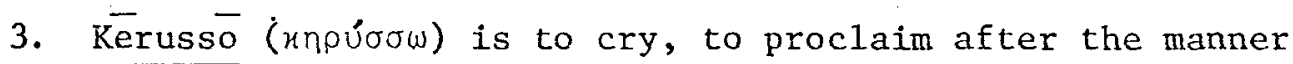
of a herald. By public proclamation, it exhorts to repentance and

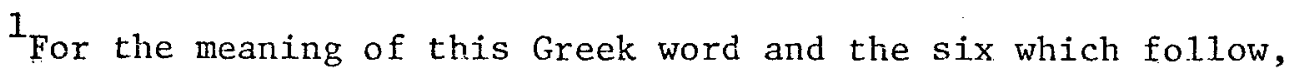
see Paul Eppinger, "Be Occupied with Preaching," Christianity Today, June 9, 1967, pp. 13-14; Joseph H. Thayer, Greek-English Lexicon of The New Testament (New York: American Book Company, 1886), pp. 256, $330,346,358,482,491,517$; James H. Moulton and George Mil1igan, The Vocabulary of the Greek Testament (Grand Rapids: Eerdmans Publishing Co., 1959), pp. 259, 324, 343, 368, 484, 497, 520. This brief section regarding the Greek words for preaching does not include the valuable and definitive material available in Kittel's Theological Dictionary of the New Testament. For a more complete understanding of the theological meaning of these words this work must be consulted. 
promises the pardon of sins. In New Testament times, the herald partook of the character of an ambassador. The office of heralds was considered to be sacred and their persons inviolable; therefore, they were employed to bear messages between enemies. So kérussō means to proclaim peace to warring peoples as the herald sent by God. Thus Paul declared: "But we preach Christ crucified, a stumbling-block to Jews and folly to Gentiles, but to those who are called. . . Christ the power of God and the wisdom of God" (1 Cor 1:23, 24).

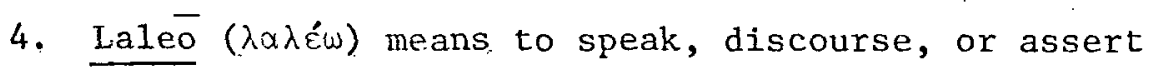
something. It is used in connection with, or as a breaking of, silence (Mk 2:2).

5. Parrésiazomai $(\pi a \rho \rho n \sigma \iota \alpha \zeta o \mu \alpha \iota)$ is to bear one's self boldly or confidently. It means to speak openly and fearlessly, to be utterly free in one's speech (Acts 9:27).

6. Pléroo ( - $\lambda$ n pów) implies to make full, to fill up so that nothing shall be wanting to make full measure. It was Paul's description of his preaching before the Romans (Rom 15:19). Paul took it as his God-given task to fill the Roman world to overflowing with the good news concerning Jesus Christ.

7. Parakaleo $\left(\pi \alpha \rho \alpha x \alpha \lambda \varepsilon^{\omega} \omega\right)$ is to call to one's side to help. This may be done in the way of exhortation, entreaty, comfort, instruction, and so forth. It is translated "exhort" in the King James Version but "preach" in the Revised Standard Version in 1 Ti 4:13. In this sense it is preaching the Word in exhortation and with encouragement, not just so it can be studied and understood, but as a challenge to action. 
From these words, Paul. Eppinger suggests that in preaching "there must be a note of 'good news' that is 'proclaimed with authority' by a 'herald sent by God' who'asserts something' 'openly, fearlessly, and fully' in order to 'challenge, strengthen, and exhort' others to Jesus Christ" in a personal, redemptive relationship. ${ }^{1}$

Although this is a good suggestion on what preaching is from the study of these Greek words, Eppinger may be saying more than can be said on the basis of the Greek words alone. It would be safer to say that the totality of the preaching ministry includes all of these aspects, but an individual sermon may include only one or two of them.

\section{What It Means to Preach}

The meaning of preaching will be considered from the following three aspects: (1) Proclaiming Gospel Truth, (2) Interpreting Gospel Truth, and (3) God Confronting Man.

\section{Proclaiming Gospe1 Truth}

Preaching is God's idea. He is interested in all human affairs and has a definite message to give to this sinful world. So He has chosen the method of preaching to communicate to man. When sin separated man from God at the Fall, God called out after man with words of redemption and judgment. He desired to continue giving man further revelations of His character. Thus preaching is not only different from the communication of historical and scientific facts but also from philosophical instruction. It is "a declaration which

\section{${ }^{1}$ Paul Eppinger, "Be Occupied with Preaching," Christianity} Today, June 9, 1967, p. 14. 
speaks directly to the hearer and challenges him to a specific action"; it is "the call which rings out and is heard" as God's cal1. ${ }^{1}$ It is a direct address from God to man and it reaches man in his own specific situation.

Paul, as a great preacher of the New Testament, has much to say about preaching. In Gal 1:11-17, he mentions how he became the gospel preacher. He was conscious of special grace to preach the good news of Christ. Like the old Testament prophets (Jer 1:5; Is $49: 1$ ), he saw himself as called by God from his mother's womb for this task (Gal 1:15; Rom 1:1; 1 Cor 1:17) and entrusted with its proclamation (Co1 1:23; Eph 3:7). He felt a "necessity" (1 Cor 9:16) to proclaim it and a pride to tell it (Rom 1:16). He clearly expressed his message thus:

It pleased God through the folly of what we preach to save those who believe. For Jews demand signs and Greeks seek wisdom, but we preach Christ crucified, a stumbling-block to Jews and folly to Gentiles, but to those who are called, both Jews and Greeks, Christ the power of God and the wisdom of God (1 Cor 1:21-24; cf. Rom 1:16).

This "story of the cross" (1 Cor 1:8) stresses the centrality of Christ in Paul's preaching. He says, "we do not proclaim ourselves, but Christ Jesus as Lord" (2 Cor 4:5), "the good news of the glory of Christ" (2 Cor 4:4), "For all the promises of God find their Yes in him" (2 Cor 1:20). He also stated in 1 Cor 15:1-7 the functional role of Christ: "Christ died for our sins." He recalls the Scriptures, the burial, the resurrection, and the appearances.

'Walter Leibrecht, ed., Religion and Culture (New York: Harper and Brothers, 1959), p. 236. 
But the preaching of Paul does not stop here. The gospel he preached is "the power of God for the salvation of every man who believes" (Rom 1:16). This means that preaching not only proclaims the redemptive event of Christ's death and resurrection but is itself a force that spreads the gospel to men. It is itself a redemptive event as it appeals to men. Paul calls the gospel "the power of God," just as he referred to Christ Himself as the power of God (1 Cor 1:24). So Paul can write to the Thessalonians that the "gospel was not preached to them in words only, but with power, and the Holy Spirit, and full conviction" ( 1 Th $1: 5$; cf. 1. Cor 4:20).

God speaks. In preaching, God is the principal subject. 1 Paul makes this clear when writing to the Thessalonian Christians. "We also thank God constantly for this, that when you received the word of God which you heard from us, you accepted it . . as what it really is, the word of God. . ." (1 Th 2:13). After appointing the seventy, Jesus said to them: "He who hears you hears me. . ." (Lk 10:16). It is He Himself speaking through those who preach. Preaching in an important way may be thought of as speech by God rather than speech about God, though it also includes God's word about Himself. "God is the one who speaks and is heard in preaching. A nearly identical text is found in the Epistle to the Hebrews: 'See that you do not refuse him who is speaking. .' (Heb 12:25-26). He who speaks here is God; it is His word which is heard in preaching."2 Therefore, it is the preacher's ducy to proclain to his fellow men

$1_{\text {Domenico Grasso, Proclaiming God's Message (Notre Dame: }}$ University of Notre Dame Press, 1965), pp. 23-46.

2 Ibid., p. 24. 
what God Himself has to say to them, since true preaching is God's word to man rather than man's word about God.

\section{God proclaims His gospel. In preaching, God's "good news"} is proclaimed. This is not just ethical instruction, nor is it the propagation of a philosophy nor the communication of doctrines. It is not human ideas about God, but rather what God has done for man: He has done many great things for men and spoken glad news to men in Jesus Christ. Gustaf Wingren said, "if. . . preaching does not contain the word of the gospel, if it is not the message of God's act, but just talk about Christianity . . then it may we11 be asked whether it is really preaching at a11."1

The gospel is not a statement, nor a doctrine, nor a scheme on man's side. It is first God's act of redemption even before it is man's message of it. Paul made this clear when he wrote to the Romans (Rom $1: 16,17$ ). Paul was sure that it was not the preaching itself that saved those who believed, for he said that it was the gospel that saved them. The gospel is the preached fact that God was in Christ reconciling the whole human race to Himself. Edmund Clowney emphasizes this:

Salvation is of the Lord, and the message of the gospel is the theocentric message of the unfolding plan of God for our salvation in Jesus Christ. He who would preach the word must preach Christ.2

${ }^{1}$ Gustaf Wingren, The Living Word (Philadelphia: Muhlenberg Press, 1960), p. 71 .

${ }^{2}$ Edmund Clowney, Preaching and Biblical Theology (Grand Rapids: Eerdmans Publishing Company, 1961), p. 74. 
The gospe1 presents Jesus Christ. The aim of true preaching

is to present Christ. He is the incarnate Word and the center of God's good news. This good news is Christ's self-witness stating the presence of His kingdom and offering Himself as man's rightful Lord and King. The Epistle to the Hebrews says, ". . In these last days he [God] has spoken to us by his Son" (Heb 1:2). Christ designs to be present by His own action in preaching. He is the content of the gospel in preaching.

God becomes man to talk to man, to show him His design of love, to start with him a dialogue between father and son, between friends. And in so speaking, He tells him who He is, what man is, what he has done for him--all in order to love him and lead hin to accept His plan of salvation. 1

Thus God has chosen Jesus Christ as His communication to man. Preaching is His life-giving word to man. Jesus told His disciples that He was the life, the truth, and the way (Jn 14:6.). This means that through Him one comes to God and becomes His child. Again, Rom 10:17 says that His followers are to preach Christ because faith comes from hearing the preaching of Christ. Paul says that he is an apostle for the gospel of God, and the gospel is about the Son, who "was born of the seed of David, according to the flesh, and was designated Son of God in power by virtue of his resurrection from the dead" (Rom 1:3, 4). He says the task of the gospel is to preach Christ. This is God's seeking of man and speaking to man. Thus, genuine preaching exalts Christ as the only Saviour for this sinful world. It is a joyful announcement that God has come to His people and reconciled them to Himself.

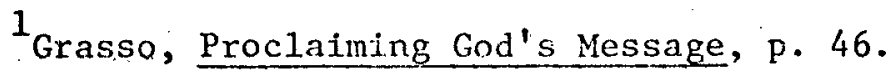


The Bible bears witness to Jesus Christ. Donald Miller

writes that "to preach is to bear witness to the unique action of God in Jesus Christ as it is set forth in the record of that action-the Bible." ${ }^{1}$. This means that the Bible is the main source for preaching since man's true knowledge of God comes from this source. Jesus claimed that "i.t is they [the Scriptures] that bear witness to me" (Jn 5:38). He is the center of all scripture. Speaking about the Bible, H. C. Brown says:

Our religious authority is God in personal self-disclosure. From the fact of God in self-disclosure comes religious authority in a multidimensional form which includes Jesus Christ, the living, revealed, personal Word of God, who is the supreme revelation of God; the Holy Spirit, who inspired the prophets and apostles so that they remembered and recorded all we need to know about God; and the Bible, which, inspired by the Holy Spirit, is God's document of revelation and which witnesses supremely to Jesus Christ.2

There is no record of Jesus' writing during His earthly ministry except once when He wrote upon the ground ( $\mathrm{Jn} 8: 6$ ). He chose the apostles and set them up as hearers and witnesses. And later they were to testify to what Jesus had said and done to save the world. So it is only through human testimony, authorized by Jesus Christ, that one can know Him. But it should be remembered that it is not the Bible which must be preached, it is Jesus Christ and His redemption. Therefore, preaching the Bible without proclaiming Him is not true preaching. The ministers of Christ do not have credentials as such to show they are "ambassadors" of

1 Donald Miljer, The Way to Biblical Preaching (New York: Abingdon-Cokesbury Press, 1957), p. 24.

${ }^{2}$ H. C. Brown, A Quest for Reformation in Preaching (Waco, Texas: Word Books Publishers, 1968), p. 35. 
Christ. "AIl we have is the content of our very message, which is Jesus Christ Himself." 1

Proclamation through a human voice. God chooses a human voice to proclaim His gospel truth to men. It was Paul who under the inspiration of the Spirit said: "Everyone who cal1s upon the name of the Lord will be saved. But how are they to call upon him in whom they have not believed? And how are they to believe in him of whom they have never heard? And how are they to hear without a preacher?" (Rom 10:13, 14). This preaching is God speaking through a man to the hearts of both Christians and unbelievers. The human word becomes the medium for the Word of God; God's chosen preacher lends God his voice so that God may use it to call out after man and to offer him salvation.

\section{Ellen White wrote:}

If the minister utters words drawn from the living oracles of God; if he believes in and expects the cooperation of Christ, whose servant he is; if he hides self and exalts Jesus, the world's Redeemer; his words will reach the hearts of his hearers, and his work will bear the divine credentials. ${ }^{2}$

God and men meet through the medium of the human word. Paul emphasizes the importance of this human instrument in 2 Cor. 5:20, preachers are the servants of the word and the living instruments through which God's word comes to men. As God's human instrument, the preacher does not seek to teach people nor please then. Rather he simply

${ }^{1}$ Dietrich Ritsch1, A Theology of Froclamation (Richmond: John Knox Press, 1960), p. $\overline{63}$.

2E1len G. White, Testimonies to Ministers (Mountain View, Calif.: Pacific Press Publishing Association, 1944), p. 144. 
tries to let the word of God speak, knowing that God alone can produce results in the end.

It is God Himself: who speaks, who announces the word of truth and salvation, but who avails Himself of the human word in order that His word may reach us. 1

So the ministers of His word preach not because they are certain of themselves, but because they are certain that Christ is their own Lord and will. speak through them. It is the power of the presence of Christ through His gospel, not the power through human skill, that matters in preaching. The preacher truly called of God is a vessel for noble use (2 Ti 2:21). God has thought him worthy to put in trust with the gospel.

Therefore, preaching is more than proclaiming an action of God, even though the action announced is the incarnation, the saving cross, the resurrection, the ascension, the priestly ministration in the heavenly sanctuary, and the second advent. It is the action of God's calling of man, the church, and the world for the sake of His Son.

Interpreting Gospel Truth

Hearing the word of God is not simple. It does, not come into human words and understanding automatically. David Randolph defines preaching as: "The event in which the Biblical text is interpreted in order that its meaning will come to expression in the concrete situation of the hearers."2 In preaching, God wants His

${ }^{1}$ Grasso, Proclaiming God's Message, p. 29.

2 David Randolph, The Renewal of Preaching (Philadelphia:

Fortress Press, 1965), p. 1 . 
people to understand Him. The Bible is the word of God, the standard of faith and practice for the Christian, and the basic source of preaching ideas and materials. It contains the good news of a Saviour who lived and died, who was resurrected from the dead, who is now our Advocate, and who is coming again soon. It reveals how man should relate to God and to one another. To every man in every age it stands paramount. But it was written in another 1anguage and in another time. Therefore, the preacher has the responsibility to interpret it and to make it present truth by the guidance of the Holy Spirit. Because of this, preaching has a close relationship with exegesis. "The word of God does not change, but the preaching situation and the needs of the people change." 1 The biblical text needs to be interpreted in order that its meaning will become relevant in the concrete situation of the present. Thus one can see the definite need of sound hermeneutics in proclaiming gospel truths. Bernard Ramm explains it this way:

If the preacher's duty is to minister. the word of God, hermeneutics is the means whereby he determines the meaning of the word of God. To ask for exemptions from the strict rules of hermeneutics is then to ask for an exemption from preaching the true meaning of the word of God. . . . Whenever scripture is used, it must be used according to sound rules of hermeneutics. 2

\section{Christ, the key to the interpretation. The center of all}

Scripture is Jesus Christ who calls man to respond in faith and obedience throughout all his life and work. As Paul says in Eph

${ }^{1}$ Ralph G. Turnbull, ed., Baker's Dictionary of Practical Theology (Grand Rapids, Mich.: Baker Book House, 1967), p. 10.

2 Bernard Ramm, Protestant Biblical Interpretation (Grand Rapids, Mich.: Baker Book House, 1970), p. 197. 
1:10, in Christ everything is unified because there everything finds its center of origin and gravity. We see that "the unity of the Bible depends on the fact that Christ is Lord. Christ is the living Lord who rises up between the two covenants, fulfilling the one and laying the foundation of the other." 1 For this reason, both the old Testament and the New Testament must be interpreted in the light of the Incarnate Word. In Jesus Christ, dwells the fullness of God's divinity ( $\operatorname{Col} 2: 9)$; in Him, God has sufficiently and finally declared Himself (Heb 1:1ff.); Christ is the very Word of God (In 1:1-14). Russe11 Snyder makes it clear when he says:

Our exposition of the Bible should not only be complete and thorough; it should also be strictly Christocentric. Christ is the key to the interpretation of the Scripture and of every worthy preaching text in the Scripture. Therefore the final test of any sermon is not merely, 'Is it Scriptural?' but 'Is it Scriptural in the evangelical sense?' Is it aflame with the gospel $?^{2}$

Historical Analysis. To discover what the text meant in its own time and place is vital. The preacher must always start here. God spoke His. word in a language and a time which are not of today, and one learns it only through the witness of the apostles and prophets. In historical analysis, the preacher seeks to discover the original setting and meaning of a biblical passage. He tries to show the meaning of Scripture to those who first received it. The aim is to go back to the biblical age and to present an objective, descriptive explanation. Since the word is for all nations and all

$1_{\text {Wingren, }}$ The Living Word, p. 57.

2 Russell Snyder, Reality in Preaching (Philadelphia: Muhlenberg Press, 1942), p. 24. 
centuries and will remain alive till the end of the world, the interpreter of gospel truth must bridge the language gap and explain the context and historical background of the biblical record.

Theological exegesis. Since the Bible deals with events in: history and with men's relation to God, the preacher must consider the historical and the theological meanings of the Bible. By the theological exegesis one means the "effort to understand the essential. truths of a Biblical passage, realizing that the Bible is significant primarily as a revelation of God to man. In other words, what is God saying to us through the text?"1

As J. Smart pointed out, historical understanding could only deal with the observable religious ideas, rites, and institutions in Scripture, it could not see in Scripture the Word of God. ${ }^{2}$. The aim of theological exegesis is to remove the wall between the first and twentieth century so that the Bible can speak to men today. The preacher has the never-ending task of interpreting the scripture to his own age. He cannot suppose that the biblical message is easily understood since his world is greatly different from the biblical wor1d,

Preaching must bring men to faith. It must clarify and build up a faith which is loyal to the Scriptures and is related to

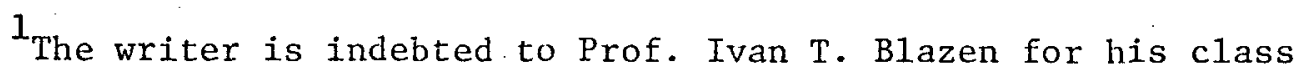
lecture on Theological foundations for Exegesis and Preaching. He explains that the purpose of theological exegesis is to declare what God is saying through the text. That is to say, the purpose of theological exegesis is to reveal the charismatic intention of the text in relation to modern time.

${ }^{2}$ Cf. J. Smart, "Beyond Historical. Interpretation," New Directions in Biblical Thought, ed. M. Marty (New York: Association Press, 1960), pp. 113-128. 
man's practical life. The preacher must carry his audience from the biblical world to the modern world. Thus theological exegesis is a bridge between the past scriptural event and a present application to modern man. However, one must give heed to what Von Allmen has said: "We are charged with translating and making present the word of God at a certain time and yet we must not adapt the word of God to our hearers, but apply it to them." 1

Holy Spirit, the sure guide. The preacher has divine power assisting him in the application of the word. Jesus wants everyone to understand Him; therefore he has promised the gifts of the Holy Spirit to guide into all truth ( $\mathrm{Jn} 16: 13$ ). It is said that the Holy Spirit is present whenever God's servants preach. He, the Comforter, will bring "all things" which Christ had taught to remembrance.

Therefore, those who preach in the name of the Lord should seek the help of the Holy Spirit so He may possess them and give the listeners true understanding which He alone can impart.

It is the efficiency of the Holy Spirit that makes the ministry of the word effective. When Christ speaks through the minister, the Holy Spirit prepares the hearts of the listeners to receive the word. The Holy Spirit is not a servant, but a controlling power. He causes the truth to shine into minds and speaks through every discourse where the minister surrenders himself to the divine working. It is the Spirit that surrounds the soul with a holy atmosphere and speaks to the impenitent through words of warning, pointing them to Him who takes away the sin of the world.2

Therefore, preaching must be an exposition of the word of God, not the word of man. It comes to the hearer as a divine

${ }^{1}$ Jean-Jacques Von Allmen, Preaching and Congregation, trans. B. L. Nicholas (Richnond, Virginia: John Knox Press, 1962), p. 28.

2 E1len G. White, Gospel Workers (Washington, D.C.: Review and Herald Publishing Association, 1.936), p. 155. 
revelation by the power of the spirit of God. It meets sinners in the total context of their daily lives with redemptive claims of God's word in the person of Jesus Christ.

God Confronting Man

Wherever God's word is present in the spoken words of preaching, God confronts man. Schroeder writes from this point of view:

Preaching is much more than talking about God or telling how God has dealt with His people in days gone by. Recalling these events is, more or less, the external, though essential, part of preaching; in, with, and under the proclamation of what God wrought in history, God is Himself addressing man and confronting him. Here and now the word of God is entering into an encounter with man. 1

Genuine preaching is not simply a discourse about an event, but it is ore itself. ${ }^{2}$ Donald Miller explains this event and adds, "To preach is to become a part of a dynamic event wherein the living, redeeming God reproduces His act of redemption in a living encounter with men through the preaching. " 3 It is an effort to lead people into the experience of meeting God. It is the experience of being touched by Him, of being spoken to, of being reached by Him. Therefore Donald Miller says, "Preaching is not mere speaking; it is an act. It accomplishes something. It never leaves a man where it finds him, but makes him either better or worse." 4

$1_{\text {Frederick W. Schroeder, Preaching the Word with Authority }}$ (Philadelphia: The Westminster Press, 1954), p. 57.

${ }^{2}$ See Richard A. Thompson, "The Preaching Event: A Review," Foundations XII (April-June 1969), pp. 187-88.

${ }^{3}$ Donald Miller, Fire in the Mouth (New York: Abingdon Press, 1954), p. 17.

${ }^{4}$ Miller, The Way to Biblical Preaching, p. 26. 
Christ-event. Talking about the miracle of preaching, Von Allmen states: "Our preaching continues the past preaching of Jesus and looks forward to the word which He will speak at His return. That is why God Hinself is at work, at this present day, when we preach." 1 So Christ is God's event, His historic action in man's behalf and Christianity is the story of what God has done for men in Christ. It is the story of God's personal approach to man. He acts for his salvation and asks man's response in faith and totaI surrender. It is the story of God's redeeming action in christ. In this event God reveals Himself and reaches out to man. He comes into contact with man, speaks to him, tells him about His plan of salvation, and through the Holy Spirit calls men to respond. Donald Miller suggests that "God's revelation of Himself was not in the rea $1 \mathrm{~m}$ of idea but in the realm of event. God told them who He was by acting in their behalf." 2 This means that by showing Jesus as the crucified, risen, and living Lord, God encounters man.

Decisive event. This encounter with God is the most decisive event in the life of man. The preached word is not just retelling God's activity in the past but God's activity in the present calling man to make the important decision for life or death. Acceptance or refusal of the preached word of God leads to acceptance or refusal of God Himself (Ijk 10:16).

The preacher tries to bring about a personal encounter between God and the souls of his hearers. He seeks to lead every man to

\footnotetext{
${ }^{1}$ Von A11men, Preaching and Congregation, p. 7. 2 Miller, Fire in Thy Mouth, p. 21.
} 
a place where he must meet God face to face and can find no way of evasion, no escape from the impact of God upon his mind and heart. 1

When a man has listened to the faithful preaching of the gospel, he is placed before the God who judges him, yet God, in His great mercy, a1so forgives and empowers him.

John the Baptist began the preaching of the New Testament period by a call to an encounter with God which leads to repentance. "Repent, for the kingdom of heaven is at hand" (Mt 3:2). Jesus also began his preaching by a call to repent (Mt 4:17).

As Jesus used Kerussein, it involved a call to decision. He sent the disciples out to announce the new age: Preach as you go, saying, "The kingdom of heaven is at hand" (Mt 10:7). The purpose of the proclamation as a summons to encounter is clearly stated: "He who receives you, receives me" (Mt 10:40).2

Sinners in their lost condition are called to a saving encounter with the gospel of God. The aim of preaching is thus to tell people about what happened long ago in order that they may gain insight into something that can happen now.

Something happens." "In true preaching, something happens." 3 The man who really believes that the word of the Lord is sharper than any two-edged sword, piercing to the division of soul and spirit (Heb 4:12), or that it is like a hammer that breaks the rock in pieces (Jer 23:20) may rest his case when he has proclaimed the word. The word surely will accomplish its intended purpose (Is 55:11). Von

1L. J. Tizard, Preaching (New York: Oxford University Press, 1959), p. 18 .

2M. R. Abbey, Preaching to the Contemporary Mind (New York: Abingdon Press, 1963), p. 47.

3 Miller, The Way to Bjblical Preaching, p. 13. 
Allmen says, "This effect is to plunge men into a crisis, to call their whole existence in question in a manner so radical that their eternal destiny will be, decided by the way in which they react." 1 The Apostle Peter's method of preaching on the Day of Pentecost is an excellent example of true preaching. He did not speak in soft, flattering speech but in clear, straight-forward language. He quoted Scripture and reasoned from it; yet, as he preached something happened in that large group of people. They were moved; the mob became a congregation. In Peter's exposition of the Scriptures, there was heard the call of God to every heart. The record says:

When they heard this, they were cut to the heart, and said to Peter and the rest of the apostles, "Brethren, what shall we do?" And Peter said to them, "Repent, and be baptized . . . in the name of Jesus Christ. . . ." So those who received his word were baptized, and there were added that day about three thousand souls (Acts 2:37-41).

Preaching is not a performance. It is an event. It is that Christevent in which the preacher, with the authority of Scripture and by the help of the Holy Spirit, brings God and man face to face in a redemptive relationship. Through the act of preaching, the power of God is present and faith is produced in the hearer. So he who hears the preaching is faced with the necessity of decision. He must repent and trust himself to the gospel or turn away.

So one may say that preaching is a dynamic Christ-event wherein the living, redeeming God reveals His act of redemption in a living encounter with men through the ambassador-preacher.

${ }^{1}$ Von Allmen, Preaching and Congregation, p. 17 . 
Hoping to create and strengthen saving faith the preacher first listens and then proclaims the gospel and interprets the given word of God in contemporary language to the heart of the individual.

This definition leads the preacher to realize his solemn privilege of being called as an ambassador for Christ. To be an ambassador for Christ; he is first of all called to sonship. Daniel

Baymann says:

No one has a claim to the pulpit of the Christian Church who has not experienced the redemptive touch of Christ upon his own life. Christ must not only be spoken of, He must be an observable part of the preacher's person. . . It is a valid assumption on the part of God's people that when the preacher stands to declare the mighty acts of God in Christ, he has first of all been mightily acted upon. Only a son can speak with deep conviction, born out of personal experience with the Father. 1

Baumann goes on to say that the preacher is also called to discipleship. He is a learner under the guidance of the Spirit of God. "Because of his encounter with Scripture and the Spirit of God, he is growing in that continuing relationship with the Father through Jesus Christ." 2 Dwight Stevenson adds: "He cannot speak on behalf of God to another until he himself has 1istened to God." ${ }^{3}$ When Jesus called His disciples, His first word to them was not "go" but "come." He said to them, "Come ye . . apart . . and rest a while" (Mk 6:31). "Come to me . . and learn from me" (Mt 11:28, 29).

${ }^{1} \mathrm{~J}$. Daniel Baumann, An Introduction to Contemporary Preaching (Grand Rapids: Baker Book House, 1972), pp. 33-34.

2 Ibid., p. 35 .

3D. E. Stevenson, In the Biblical Preacher's Workshop

(Nashville: Abingdon Press, 1967), p. 67. 
The preacher is also called to be an ambassador for Christ. He is a man sent from God. His mission is not of his own choosing. He is a man with an authority, a message, and a responsibility. His authority comes from above; his message is God's good news concerning Jesus Christ; and his responsibility is that of sharing the truth which God Himself has made known. James Stewart says:

God wants no grovelling, faint-hearted creatures for His ambassadors, He wants men who, having commune with heaven, can never be intimidated by the world. . . . He [the preacher] is not diffidently offering men the dubious result's of his private speculation: He is standing on his feet to deliver to them, in the name of the King of kings, a word that cannot return void.1

Furthermore, the preacher should know his congregation and the basic issues that concern his people. He needs to consider the background of their experience, their attitudes, beliefs, notives, and habits. Seated before the pulpit are the children who must be fed on the "milk of the word," the inquiring teen-ager, the doubting college student, the professor, the widower, the homemaker, and the businessman. There are the aged who need strength; there are the sick who need health; there are the burdened who need solace; there are the guilty who need pardon. There are the disappointed; there are the lonely. All of these sit before the preacher and wait for the word to say something to them in their particular situations and for their personal needs.

How can a preacher with only human ability reach the hearts of all? The task is not an easy one. It requires the best a man has to give. Nevertheless, it is reassuring to know that preaching is not simply a human activity. Von Allmen says:

$1_{\text {James S. Stewart, Heralds of God (New York: Charles }}$ Scribner's Sons, 1946), pp. 211, 214. 
Wi.thout the work of the Holy Spirit the word which God has spoken to the world in His Son cannot be effectively translated or made present. . . We are not only ministers of Christ but also agents of the Holy Spirit and His work.1

How grateful ministers should be that they are not àlone in preaching; the Holy Spirit stands by their side.

It is an amazing privilege to be called to the ministry of the word; to be conscious of a heavenly mission and authority; to be entrusted with a gospel which is still the power of God to sal.vation and is utterly adequate for all the complexities of modern life; to be allowed to point men, women, and young people to the only way of 1ife in this world and the only hope for the world to come; to be Christ's ambassadors and fellowworkers with God in the greatest of all tasks--the making of disciples, the building up of the church, the advancement of the kingdom in the world.2

It is a satisfying task. God has revealed Himself to men, and ministers can declare to men His steadfast love throughout their existence. Above all, they are able to sing for joy at the works of the Lord (Ps 92:1, 2, 4). They preach because something is happening and has happened to them.

Although there are several dynamic elements in the preaching event--me word, the Holy Spirit, the preacher, and the congregation-m this project will be limited to emphasize one phase of the preaching event, that is, the Bible and its place in preaching. This will be discussed in the next chapter.

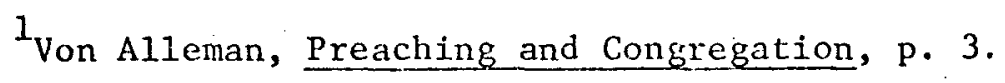

${ }^{2}$ Colquhoun, Christ's Ambassadors, p. 38. 
CHAPTER II

THE BIBLE AND ITS PLACE IN PREACHING

It is the purpose of this chapter to clarify and examine the implications of the conviction that preaching must be based on the message of Scripture. That is to say, the message of a preacher should not come from contemporary issues, current trends of one sort or another, nor even from the preacher's own reflection, it should come from the Scriptures. If the preaching cannot be honestly related to the Bible it cannot be called Christian preaching.

\section{Why Preaching from the Bible?}

There is a fundamental principle clearly stated in 2 Ti

$3: 15-4: 2$ which reads:

You have been acquainted with the sacred writings which are able to instruct you for salvation through faith in Christ Jesus. A11 scripture is inspired by God and profitable for teaching, for reproof, for correction, and for training in righteousness, that the man of God may be complete, equipped for every good work. I charge you in the presence of God and of Christ Jesus, . . : Preach the word. . (RSV).

This text openly acknowledges that all the Scriptures are inspired of God. They are God-breathed and contain the breath and the presence of God. On this basis Paul makes an appeal to his young son in the ministry that he "preach the word." This is the preacher's assignment. To this, Frank Colquhoun adds, "The Bible is the preacher's text book, in the sense that it is the authoritative word 
which it is his main business to expound and on which he bases the whole of his message." 1 Furthermore, Criswell asserts that:

[Christian faith] is built upon authority, and without that authority faith is sheer speculation. . . If there is to be real religion, somewhere, sometime, somenow God must speak. God must disclose. Himself. Has He spoken? Has He revealed Himself? If so, where is the spoken word? Where is that revelation? The answer is, in His infallible book, the Bible. ${ }^{2}$

The Uniqueness of the Bible

The Bible claims to be an authoritative book and a reliable guide to the true knowledge of God and His plan of salvation. It firmly claims its divine authorship. The letter to the Hebrews begins with these words: "In many and various ways God spoke of old to our fathers by the prophets; but in these last days he has spoken to us by the Son" (Heb 1:1,2). Here, the Bible states that God has spoken in ancient times. The prophets were the spokesmen for God. Their message came in earlier times and differing manners. While the author of the letter to the Hebrews recognized the old Testament as a revelation from God, he went on to say that God has given an even fuller revelation of Himself through His Son. If this is true, that God has spoken by the prophets and by His Son, and if all Scripture is God-given, then the authority of Scripture is the authority of God Himself. Samuel Cartledge states that

it is in this area of the special revelation of God to man that we find the true distinctive characteristics of our Christian

${ }^{1}$ Colquhoun, Christ's Ambassadors, p. 41.

2. A. Criswell, Why I Preach that the Bible is Literally True (Nashville: Broadman Press, 1969), p. 132. 
faith. It is here that we come to know the fuller characteristics of our God, and it is here that we come to know of the provision that He has made for our eternal salvation through His Son, Jesus Christ. 1

Talking about the divine authority of the Bible, Benjamin Keach adds, "The Bible is of divine origin, inspired by the Spirit of God, and therefore, infallible truth and authority appears. $" 2$ The Bible bears its own testimony to that inspiration in $2 \mathrm{Pe}$ 1:21: "men moved by the Holy Spirit spoke from God." It is the Holy Spirit who inspired the authors of the Bible to produce the Book.

There are many other things which point out strongly that the Bible is much more than a mere human book, that in some very real. sense it is a revelation from God. One evidence is the organic unity in the whole of the Bible. The same God is seen from Genesis to Revelation. There is the same attitude toward sin. There is a great theme that runs through the Bible--the divine plan of redemption. There is one personality who stands out above all others. He is the goal to which all life moves. It seems that the Bible exists to reveal Jesus Christ.

Furthermore, the Bible reveals to a11 truths able to bring them into living union with God. Its truths change the hearts and lives of men and women because it is a living message containing within itself God's own life (Jn $5: 24,39$ ). It is a life-giving

${ }^{1}$ Samuel Cartledge, The Bible: God's Word to Man (Philadelphia: The Westminster Press, 1961), p. 10.

${ }^{2}$ Benjamin Keach, Preaching from the Types and Metaphors of the Bible (Michigan: Kregel Publications, 1972), p. xiii. 
word ( 1 Pe $1: 23)$. It appeals to all men through all ages and throughout every place and to every status in life. It never grows old (Is 40:8). It is a fountain of infinite wisdom springing up into everlasting 1ife ( In $6: 51$ ). It has the nature of God, who is eternal. It is the indestructible, eternal, enduring word of God (Ps 119:89; Mt 5:18). From these mentioned texts one has to agree with H. C. Brown, who writes: "Since the only authentic document for authoritative content about God in personal revelation is the Bible, the task of the preacher is to use the Bible correctly in sermon preparation and delivery." 1

\section{Jesus' Example}

When Jesus was on earth, the record indicates that the common people heard Him gladly because He "taught them as One having authority" (Mt 7:28, 29). He believed and taught the infallibility of Scripture. He regarded it as divine authority and as the final word concerning God's will and plan. Constantly, His comments were, "Have you never read?" and "It is written," and "Search the Scriptures" (Mt 19:4-5; Lk 24:44; Jn 6:39). He set llis seal to its historicity and to its being a revelation from God. He

never set aside the Scriptures in favor of an encounter with God. To Him, the Scriptures were the medium and the test of the encounter. His attitude towards the Scriptures were one of total trust. It was the direct written word of God to man.2

Throughout Jesus' earthly life and ministry, His acquaintance with the word of God was clearly seen. In the story of His temptation in

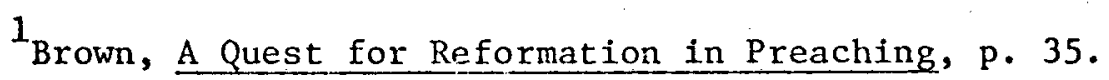

${ }^{2}$ Criswell, Why I Preach That the Bible is Literally True, pp. $19,20$. 
the wilderness, three times He used the word of God from the book of Deuteronomy. His defense for Satan's assault was, "It is written" (Mt 4:4, 7, 10). Here Jesus puts Scripture, the word of God; in contrast with the temptation of Satan. ${ }^{1}$

When Jesus began His public ministry in Nazareth, He began it by reading from the book of Isaiah ( $\mathrm{Lk} 4: 16-21$ ). In His teaching He clearly stated that the Law of Moses is the word of God (Mk 7:13). In Mt 22:44-45, He made reference to Psalm 110 and said that David was completely under the Spirit's influence. There are other similar instances which show Jesus' attitude toward the Scriptures. He never questioned the genuineness of any Bible book, and He clearly assigned the Scriptures to the writers whose names they bear (Mt 24:15). He rebuked His countrymen for their ignorance of the Scriptures (Mt 19:5) and for making the Law useless through their tradition (Mt 15:3). So often the word "Scripture" was placed on the lips of Jesus in all of the gospels. And in every case one sees Jesus recognizing the Scripture as the authority in every matter of religious concern. Thus,

The authority of Christ settles for us the question of the inspiration of the Bible. It is wholly inspired and is our medium of God's power in this life and of God's salvation in the world that is yet to come. Then, if this book was true enough for Christ, it is true enough for every Christian. 2

$1_{\text {Even Satan recognized the authoritative nature of Scripture }}$ and quoted it in one of the temptations--though he put a completely false interpretation upon it and sought to use it for an evil purpose. p. 24 .

${ }^{2}$ Criswell, Why I Preach That the Bible is Literally True, 
God's Word and Human Needs

"It is written, 'man shall not live by bread alone, but by every word that proceeds from the mouth of God'" (Mt 4:4). This is the simple, but complete, justification of preaching from the Bible. People can find strength and help from the word of God.

The word of God is a veritable fountain of life and healing. - . The Bible has no equal in its message to the human heart. It is practical and relevant, designed by God to be applied directly to the needs of life, reaching people where they are. 1

God made man. Because of this, man should not ignore God and His word. He told everyone the true, meaningful way of life and how all may overcome sin. Men's sins bring discouragement and failure. The Bible has the only clear answer to the problem (1 Jn $2: 1,2)$. When men come face to face with their sins and confess them before God, there is forgiveness from Him and a new sense of purity and healing (1 Jn 1:9; Jas 5:16). The Bible also teaches how men may find strength in a Christian life (Php 4:12, 13). Today, people are tired of the defeated lives they live. They come to church hoping that the word of God will reach into their hearts and meet their needs and give them victorious lives. They want to be changed. All week long they hear the words of man. They are burdened by the problems of life, and when they come to church they want to hear a word of hope from God.

People today are starving for real food, the Word of God, just as in the days of Hosea in the 01d Testament (Hos 4:6). They need to be nurtured by the word of God. It is the responsibility

$$
{ }^{1} \text { Ibid., p. } 125 \text {. }
$$


of the minister to preach the word and feed the congregation with the bread of 1ife. The experience of the disciples on their way to Emmaus is a good example of this. They were discouraged and depressed.

Jesus had been killed, and they did not know that He had been

resurrected. What was it that brought light and joy to their lives under such depression? The presentation of the word of God. While Christ, whom they did not recognize at first, was explaining the word, they saw the promises, the prophecies, the plan of salvation. They saw Christ in the Scriptures. Later on, as the two disciples shared what the experience had meant to them, they said to each other, "Did not our hearts burn within us, while he talked with us by the way, and while he opened to us the scriptures?" (Lk 24:32).

Talking about the reasons for using the Bible in preaching, John Knox has said:

It is not because the Bible is made up of, or contains, God's words that we call it the word of God, but because it conveys to us this presence and this mighty action. Now Christian preaching is attempting to convey this same presence and this same mighty action. It, like the Bible itself, is concerned with the event of Christ, seeking to communicate its reality and its relevance, to interpret its meaning for the men of every generation and for man in all the generations. The Bible, therefore, is not merely useful in preaching, it is absolutely indispensable. It is nore than a supremely useful resource in preaching; it belongs essentially to the very source of preaching. It is not only true that preaching should be biblical; authentic preaching has to be! ${ }^{1}$

For these reasons--its authority, Jesus' example, and its practicality-Christian ministers preach from the Bible.

At this juncture something should be said about the position of Seventh-day Adventists. I.t is the belief of Adventists that "all

${ }^{1}$ John Knox, The Integrity of Preaching (New York: Abingdon Press, 1957), pp. 14, 15 . 
scripture was given by inspiration and constitutes the very word of God. It is the truth that liveth and abideth for ever" (1 Pe 1:23). Adventists also recognize that the Bible is the ultimate and final authority on what is truth. Through the ministry of these messengers of old, Jehovah declared His truth to the world (Dt 18:18). The word which these prophets spake and wrote was not their own; it was the word of the 1iving God (Eze 3:1-4, Jer 1:9). Adventists hold the Protestant position that the Bible and the Bible only is the sole rule of faith and practice for Christians. They believe that it does not merely contain the word of God, but it is the word of God. ${ }^{1}$ As ministers look at the Bible in this 1ight, the needs of theix audiences can be met. J. S. Stewart in his book A Faith to Proclaim says:

The unspoken cry of every gathered congregation to the preacher is not "Is there any bright idea from the current religious debate?" but "Is there any word from the Lord?--". not "we would see what advice may be available," but "we would see Jesus."2

It is this urgent appeal of the human heart that continually leads the preacher back to the Bible. It is his privilege to be the servant of the word of God. Only in this way is he an ambassador of God and a man under authority. With God's Book in hand, the minister can proclaim wi.th authority and power the living message of the living God. With great assurance he can call men to repentance and

$1_{\text {Seventh-day Adventists Answer Questions on Doctrine }}$ (Washington, D.C.: Review and Herald Publishing Association, 1957), pp. $26-28$.

2J. S. Stewart, A Faith to Proclaim (London: Charles Scribner's Sons, 1953), p. 29. 
faith in Christ Jesus. By the gracious promise of the word of God he can speak to the people concerning the great matters of faith, life, death, and judgment to come. Therefore, the ministers should recognize that the Bible is the only testing ground for their preached message (Is $8: 20$ ).

F. D. Whitese11 stated his conviction:

Our world today needs nothing more than faithful Biblical preaching. We live in a confused, worried, groping, and lost world. It is looking for a way out. All human philosophies, panaceas, and programs have failed. Chaos, tragedy, and destruction impend. Biblical preaching is God's ordained way to meet the needs of such a world as this. The eternal truths of God's word, ringing out in freshness and power from every Christian pulpit in the world, could bring light, hope, comfort, courage, and salvation to our bewildered generation. Biblical preaching is adapted to such a day as this. 1

Qnly as ministers preach in harmony with God's given message which is found in His word can they be sure that they are doing God's will and that the faith of His people will be built and blessed.

\section{What Is Biblical Preaching?}

Having said in the first section that preaching should be founded on the Bible, the next step is to define what biblical preaching is and to see what its characteristics are. Many people think that if the sermon refers to the Bible, it must be biblical. John Knox says, "It is possible to preach a quite unbiblical sermon on a bibljcal text; it is also possible to preach a quite biblical sermon on no text at a11." ${ }^{2}$ Some preachers believe that a sermon

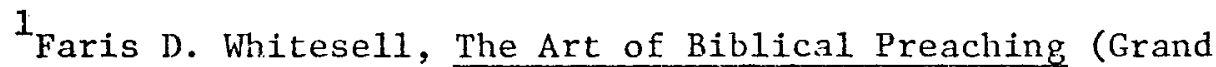
Rapids, Mich.: Zondervan Publishing House, 1950), pp. 15, 16.

2 Knox, The Integrity of Preaching, p. 19. 
must be heavily weighted with the exact words of Scripture. Yet as Knox says, a sermon can be biblical without any text and a sermon with many texts can be most unbiblical. This does not mean that one should use the Bible in a hidden fashion in his preaching. Biblical preaching should show clearly its dependence on passages from Scripture.

There are many definitions given to biblical preaching: "The translation of both the gospel and man's situation today into modern existentialist terms"; "the existence of a well-chosen biblical text which supports a seed-thought, idea, or topic which the preacher has gained from his own experience or reading"; "the self-witness of Christ, who chooses to reveal Himself through an exposition of a passage of Scripture by a fallible preacher"; 3 "the systematic exposition of the fundamental doctrines of the Christian faith which is based on thorough biblical exegesis." 4 The term "biblical preaching" is used so loosely that it is necessary to find in what sense preaching may be called "biblical."

A useful definition of biblical preaching comes from Faris $D$. Whitesell:

That preaching stemming out of the Bible, rooted in the Bible, saturated with the Bible, and harmonious with the whole

$1_{\text {Gerhard Ebeling, Word and Faith (Philadelphia: Fortress }}$ Press, 1963), pp. 322-333.

2 Ilion T. Jones, Principles and Practices of Preaching (New York: Abingdon Press, 1956), pp. 71-73.

3 Barth, The Preaching of the Gospe1, p. 9.

${ }^{4}$ Farmer, The Servant of the Word, p. 105. 
range of revealed truth is Biblical preaching. This preaching, in humble dependence upon the Holy Spirit, exalts, unfolds, interprets, illustrates, enforces, and applies the word of God. ${ }^{1}$

John Knox adds that it: (1) remains close to the characteristic and essential biblical ideas; (2) is centrally concerned with the central biblical event, the event of Christ; (3) answers to and nourishes the essential life of the church; and (4) is preaching in which the event in a real sense is recurring. 2

For practical purposes it is necessary to look at the nature of biblical preaching under the following three headings: preaching from the word of God; preaching in the power of the Spirit; and preaching with persuasive skill for a response.

Preaching from the Word of God

Biblical preaching is dependent on both the old and the New Testaments. It sees the whole Bible as fully inspired and as most useful material for preaching. It stays within God's Book and explores the treasures of divine revelation. Being faithful to the whole word of God, it leads people to the biblical truth.

It is a witness to God. Since "the Bible is the book of the acts of God," 3 biblical preaching bears witness to God's loving kindness toward sinners and His mighty power of saving men and women from sin. God is not hidden somewhere in the background, but He is the center of the biblical sermon. God reveals Himself and guides the mind of man to appreciate the revelatory character of His acts.

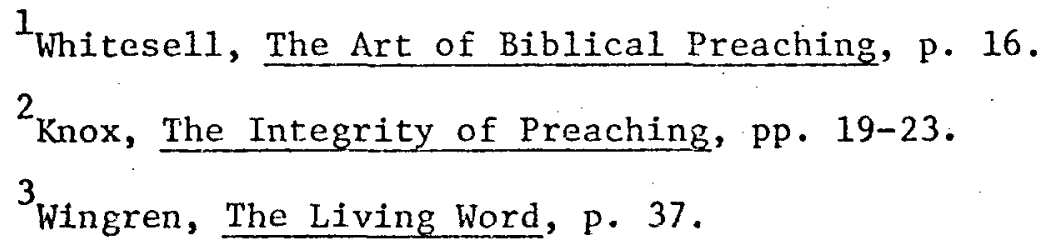


It is Christ-centered. Biblical preaching does not present

a set of ideals nor mere revealed truths. Its message focuses on

Jesus Christ, the Incarnate Word. He is the main character and theme

of the whole Bible. Knox says,

The mere treating of incidents . . does not qualify preaching as biblical unless the incidents and teachings are seen and presented in their relation to God's total act of redemption which culminated in the life and death of Jesus, the Resurrection, the coming of the Spirit, and the creation of the church.1

Paul's authority to preach was not the result of his excellent eloquence (1 Cor 2:4) or personal status ( 1 Cor 15:9). It was the authority of God who had entrusted him with "the message of reconcilation" (2 Cor 5:19). In Christ the ministry has a great fact to explain. Christ is the answer to all problems. He should be uplifted before the world. He is the great center of attraction. E1len White insists:

Let the science of salvation be the burden of every sermon, - Bring nothing into your preaching to supplement Christ, the wisdom and power of God. . . . Present the truth as it is in Jesus; making plain the requirements of the law and the gospel. Present Christ, the way, the truth, and the life, and tell of His power to save all who come to Him. . . . No discourse should ever be preached without presenting Christ and Him crucified as the foundation of the gospel. . . The sacrifice of Christ as an atonement for sin is the great truth around which all other truths cluster. In order to be rightly understood and appreciated, every truth in the word of God, from Genesis to Revelation, must be studied in the light that streams from the cross of calvary.2

He is the gospel. The message of the preacher is thus primarily determined by the event centering in the life, death, resurrection,

\footnotetext{
${ }^{1}$ Knox, The Integrity of Preaching, p. 20.

2 White, Gospe1 Workers, pp. 160, 154, 158, 315.
} 
priestly ministration and the second advent of Jesus Christ. Donald Miller adds:

Basically, Christianity is not a body of ideas, not a way of looking at life, not a philosophy of meaning, not a technique for successful or happy living. It is the story of what God has done for man in Christ. And the story must be told. "Good news" is of something that has happened, and man must know that it has happened.1

Therefore, the ambassador for Jesus Christ must present Jesus Christ so that men may know Him, love Him, trust Him, and give their lives to Him in obedience to His word.

The kingdom of God announced. Biblical preaching announces the kingdom of God and invites men to enter. John the Baptist, the forerunner of the Messiah, began his preaching in the wilderness by saying, "Repent, for the kingdom of heaven is at hand" (Mt 3:2). In the same way Mark records the beginning of Jesus' ministry with the announcement that the kingdom of God is at hand (Mk 1:15). When sending out His twelve disciples, Jesus charged them to preach as they went, saying, "The Kingdom of heaven is at hand" (Mt 10:5-7). Then in His mountain-top sermon, He compared the gospel of the kingdom to a treasure in the field or a pearl of great price which was infinitely more valuable than a man's life or any earthly treasure (Nit 13:44-46). It was compared to a great banquet to which all men were invited to come and enjoy His feast (Lk 13:29). He: preached that the new age was present in His person, meeting man with a demand for obedience and an offer of forgiveness (Mt 12:28). His invitation to enter His kingdom was proceded by His call to repentance

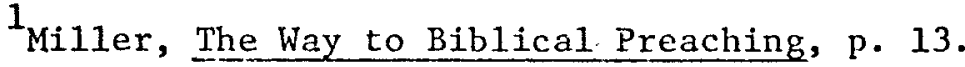


and faith (Mk 1:15). Jesus expressed the words of judgment to an evil and adulterous generation which disobeyed His call to repent and refused His invitation to enter the kingdom of God (Lk 13:3, 5).

The Sermon on the Mount was not a new code of conduct for a11 men, but an exposition of the new life of the kingdom for those who lived under Christ's reign. The kingdom was present in God's power and glory, confronting men with a call to repentance. 1

Preaching is Teaching. Biblical preaching includes not only the proclamation of the "good news" calling men to a decision but also the instruction which explains and translates the meaning of the gospel for life today. Preaching and teaching are closely related. It is the preacher's task to declare the gospel and to explain its truths and meaning. Its aim is to make the Scriptures clear, to lead people to the understanding of Christian doctrine, and to call them to respond in faith. "Every Scripture passage is either directly or indirectly related to the doctrines of the Bible. Doctrine is teaching and one cannot handle the Scriptures without doing some teaching." 2 Wingren illustrates the corollary function of preaching and teaching by pointing to the Epistles, which clearly preach the Kerygma, on the one hand, but are addressed to Christian congregations, on the other hand--like 1 Peter. ${ }^{3}$ John Knox also asserts. that it is quite unlikely that two separate functions existed for

${ }^{1}$. E. Johnson, Biblical Preaching Today (Ann Arbor, Mich.: University Microfilms, A Xerox Comp., 1972), pp. 4, 5.

2 Whitese11, The Art of Biblical Preaching, p. 18. 3 Wingren, The Living Word, p. 18. 
preaching and teaching. ${ }^{1}$ It seems impossible to preach the gospel without getting into instruction and exhortation. Though the two functions of preaching and teaching are different, they are so closely related that it is hard to separate them.

In the New Testament, though Jesus came to preach, He was presented as a teacher most of the time. His command to carry the gospel into all the world has the verb "teach" in Matthew, but in Mark it is "preach" (Mt 28:19, 29; Mk 16:15). Furthermore, there are several records of the early church which mention that the apostles both preached and taught the one gospel of God (Acts 5:42; $15: 35 ; 28: 30,31)$. Because of this knox wrote:

We need to realize that unless preaching is teaching, it is not preaching. . . His [the preacher's] primary responsibility is for the understanding of the truth and meaning of the gospel and for the comnunication of this truth and meaning as clearly and persuasively as possible. 2

The preacher should do more and more of teaching the word in preaching.

Biblical preaching speaks to the ultimate needs of men. This does not suggest that the hearer's needs take the place of the gospel as the source of preaching, but it suggests that the sermon has a particular direction and purpose--the congregation who listens. ${ }^{3}$ The gospel of Christ has power to reveal man's conscious everyday needs as well as his ultimate needs.

$1_{\text {Knox, The Integrity of Preaching, pp. 47-57. C. H. Dodd }}$ seems to make clear distinction between didache and kerygma. Teaching was given to the believers and preaching was given primarily to nonChristians, see his book, The Apostolic Preaching.

${ }^{2}$ Knox, The Integrity of Preaching, pp. 55-56.

${ }^{3}$ See Barth, Preaching of the Gospel, pp. 12-20. 
The preaching and teaching of Jesus was often introduced by His observing the multitudes and seeing their particular needs. The gospel and the sermon are personal, intimate addresses to human need. ${ }^{1}$

In order to meet the needs of man, Christ identified with man. The God "who sits above the circle of the earth" (Is 40:22) became our Elder Brother. The Holy One dwells with man and for man (Lk 1:35). He is Immanuel. Therefore in biblical preaching the preacher should become involved in the lives of the hearers. He should enter into their lives and mingle with them that he may sense their specific needs. The preacher who knows and loves his people wi11 be sensitive to their hopes and fears, successes and failures, loves and hates, selfishnesses and sacrifices. He does not proclaim the good news as one who is better than his people but as one who is with them. So as a minister of the word he needs not only to hear the word constantly afresh in his own life but also to consider the people entrusted to him, if he is to show them that God is speaking to each one individually. The minister should not preach Christ in general terms, he should preach Christ for each and every member of his congregation.

Pierre Marcel has put it this way:

Preachers need a spirit of wisdom together with an acquaintance of those to whom they are to proclaim the word. Their dispositions and their inclinations, their weakness and their needs must be taken into consideration if we are to try to lead them to God through Christ. 2

${ }^{1}$ Gene E. Bartlett, The Audacity of Preaching (New York: Harper and Bros., 1962), pp. 84ff.

2 Pierre Marcel, The Relevance of Preaching (Grand Rapids, Mich.: Baker Book House, 1963), p. 71 . 
Preachers should remember that people wish preaching to be edifying, moving, consoling, and that it present the gospel. They also wish preaching to be practical for personal daily needs.

Thus far, the writer points out that biblical preaching is preaching from the given word of God, molded throughout by the sound teaching and spirit of the Bible. It is a witness to God and to a Christ-centered Gospel for individual sinners, and it meets the real needs of contemporary man. Now he will note further that it is the preaching in the power of the Spirit.

Preaching in the Power of the Spirit

Jesus at the time of His ascension made the promise: "You shall receive power when the Holy Spirit has come upon you; and you shall be my witnesses in Jerusalem and in all Judea and Samaria and to the end of the earth" (Acts 1:8). Christ's witnesses are assured that preaching, based on the word of God and the testimony of Christ, has the sure promise of the Spirit's cooperation.

Paul experienced the promise of Jesus and wrote to the Christians in Corinth saying, "My speech and my message were not in plausible words of wisdom, but in demonstration of the Spirit and power, that your faith might not rest in the wisdom of men but in the power of God" (1 Cor 2:4,5). Realizing Christian preaching as a spiritual gift, Paul also speaks of his own preaching as being "in words not taught by human wisdom but taught by the Spirit, interpreting spiritual truths to those who possess the Spirit" (1 Cor 2:13). 
Apostolic preaching was in the power of the Holy Spirit, and if our preaching is to be biblical in the sense of following the Biblical pattern, it must be energized by the Spirit of God. . . If we would interpret Scripture rightly, relate Scripture to Scripture spiritually, quote Scripture appropriately, and apply Scripture incisively, we must be under the control of the Holy Spirit. 1

The church in Jerusalem prayed and they were all filled with the Holy Spirit and spoke the word of God with boldness. And with great power the aposties gave their testimony to the resurrection of the Lord Jesus (Acts $4: 31,33$ ). The Holy Spirit is a unique partner of the biblical preacher. Peter testified to this when he said, "The things which have now been announced to you by those who preached the good news to you through the Holy Spirit sent from heaven" ( $1 \mathrm{Pe} 1: 12$ ). This means that the biblica1 preacher is used by the Spirit and the constant, faithful support and guidance of the Spirit are promised to him. That is why Paul was able to remind the Thessalonian believers: "For our gospel came to you not only in word, but also in power and in the Holy Spirit, and with full conviction" (1 Th 1:5).

John Knox has said that "true preaching from start to finish is the work of the Spirit." ${ }^{2}$ In other words, the preacher should realize that true preaching is an action of the Spirit. "He inspires preparation, grants unction in delivery, and produces all significant results that follow the preaching event." ${ }^{3}$ Whitesell explains further and says:

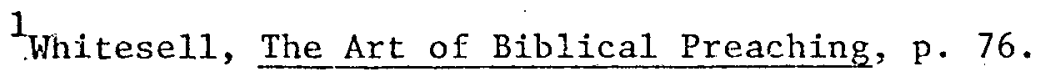

2 Knox, The Integrity of Preaching, p. 89.

${ }^{3} J$. Daniel Baumann, An Introduction to Contemporary Preaching, p. 277 . 
He can guide us in choosing the right Scripture passages for each occasion; guide us in the selection of books to buy and use in studying the Bible; give us illumination and insight in studying the passage; aid our memory to recall parallel passages and fitting illustrations; give us joy in concentrating on the text and the strength to push through the writing or verbalizing of the sermon; give us boldness and confidence at the time of delivery; inspire us with new thoughts during delivery and cause us to omit less appropriate ones. He can unify the audience, create attentiveness, open hearts, and apply the word in both expected and unexpected ways. The Holy Spirit can convict, convert, comfort, inspire, reprove, correct, and instruct in righteousness. He can fix the word in the minds and memories of hearers so that it becomes fruitful like the seed on good soil. How foolish to try to prepare sermons and preach them apart from the power of the Spirit.1

Thus in biblical preaching, the power of the Holy Spirit is clearly

fe1t. As Teacher, the Holy Spirit guides the servants of Christ to teach them all things ( $\mathrm{Jn} 14: 26$ ), to guide them into a1l the truth (Jn 16:13), and to glorify Christ throughout the course (In 16:14). This Christ-centered nature of the testimony of the Spirit is felt in the church.

The book of Acts and the Epistles have shown the fact that the Spirit changed people through preaching. William Thompson says, "The preacher does not control response, the Holy Spirit does."2 So one can expect the Holy Spirit to bring conviction.

The power is derived from the Holy Spirit. There is as much difference between preaching "in the Spirit" and preaching by human strength alone as there is between living "in the Spirit" and living "in the flesh." 3

${ }^{1}$ Farris D. Whitese11, Power in Expository Preaching (Westwood, N.J.: Fleming H. Revel1 Co., 1963), pp. 144-5.

${ }^{2}$ William Thompson, A Listener's Guide to Preaching (Nashville, Abingdon Press, 1966), p. 96.

3 Dale Moody, Spirit of the Living God (Philadelphia: Westminster Press, 1968), p. 83. 
Jesus promised the Holy Spirit so that He would "convince the world of sin and of righteousness and of judgment" ( $\ln 16: 8$ ).

Therefore preachers must trust the Holy Spirit to make the truth real to the hearers. They are not just discussing past events nor drawing spiritual lessons out of life. But through God's inspired words the past events are happening again. Knox says:

Here is the final test of Christian preaching, if it be genuine preaching and genuinely Christian: Does it really convey the saving action of God? . . . Something is being said, but nothing is taking place. The judgment and saving event of Christ is not recurring. The Spirit, the "glorious might" of God is not present. 1

In the power of the Spirit, biblical preaching leads people into the presence of a holy God. There people are moved, cleansed, empowered, and refreshed. Peter said this is the divine power which allowed men to become "partakers of the divine nature" (2 Pe 1:3,4).

\section{Preaching with Persuasive Skil1}

Biblical preaching should be persuasive and be seeking a loving response.

The ultimate goal of preaching is not just giving the information but the call to make a right decision. It involves transformation of persons; not simply data exchange, but behavioral change.

Christ's method was the method of love. His message of love calls for a love response. God "desires only the service of love; and love cannot be commanded; it cannot be won by force or authority. Only

${ }^{1}$ Knox, The Integrity of Preaching, pp. 93, 94.

$2 \mathrm{~J}$. Daniel Baumann, An Introduction to Contemporary Preaching, p. 236 . 
by love is. love awakened." 1 In his invitation to Nicodemus, He said, "Truly, truly, I say to you, unless one is born anew, he cannot see the kingdom of God" ( $\mathrm{Jn} 3: 3$ ). Paul, believing in the transforming work that can take place in the 1ives of men, also said, "If any one is in Christ, he is a new creation; the old has passed away, behold, the new has come" (2 Cor $5: 17)$.

Remember that every soul before you has its own story of need, and that if the gospel of Chxist does not meet such need nothing on earth can. Ain at results. Expect mighty works to happen. ${ }^{2}$

Therefore, biblical preaching should have several persuasive skills in its presentation.

It should be interesting. Biblical preaching by its freshness and by the love which the message contains, should catch the attention of those who are in the audience. Jesus caught the attention of the wonan of Samaria by presenting the truth in a very interesting manner and finally led her to the right response into faith. Colquhoun said, "It is the job of a preacher to make the Bible come alive and allow it to speak to his hearers with power as the contemporary word of God." ${ }^{3}$

It should be interested in persons. Biblical preaching should be interesting because it is interested in people individually. According to M. Reu, "preaching is fundamentally a part of the care

$1_{E}$. G. White, Desire of Ages (Mountain View, California: Pacific Press Publishing Association, 1940), p. 22.

2 James S. Stewart, Preaching (London: English Universities Press, Ltd., 1955), p. 42.

${ }^{3}$ Colquhoun, Christ's Ambassadors, p. 54. 
of souls, and the care of souls involves a thorough understanding of the congregation." 1 This means that the preacher should study his audience and, with the help of the Spirit of God, adjust his presentation. When the preacher fails to know his people he should not blame the audience for being unwilling to believe his sermon or to attend his preaching service.

Jesus' preaching was never a dull, spiritless presentation but was always interesting and relevant because He was really concerned about people (Mk 6:34). Ellen White, writing on Jesus' preaching, says:

The beauty of His countenance, the loveliness of His character, above a11, the love expressed in look and tone, drew to Him all who were not hardened in unbelief. Had it not been for the sweet, sympathetic spirit that shone out in every look and word, He would not have attracted the large congregations that He did. The afflicted ones who came to Him felt that He linked His interest with theirs as a faithful and tender friend, and they desired to know more of the truths He taught. ${ }^{2}$

Today people need to feel there is a concern for them each indi* vịdually. Unless they are approached with a Christlike attitude and method they will never respond to Christian preaching. That is to say, in biblical preaching ministers ought to value the worth of every individual as an individual, each as a child of God.

It should have variety. Although the gospel of Christ never changes it should be presented in various forms. Just as the Scripture has much variety of content in the truth it reveals, so

${ }^{1}$ Johann Michael Reu, Homiletics, trans. Albert Steinhaeuser (Grand Rapids: Baker Book House, 1967), p. 129.

2 White, Desire of Ages, pp. 254-255. 
is the variety of preaching it unlimited. The preaching of Jesus

in the gospel record "included parables, poetry, eschatological sayings, instruction, exhortation, aphorisms." 1 In the same manner:

"Biblical preaching is nct confined to any single method of handling the Scriptures, but utilizes all of the standard homiletical procedures." 2 This suggests that a sermon may be doctrinal, evangelistic, ethical, or life-situational and still be biblical if its approach to the subject is based on the Scriptures and if it gives true biblical light on the contemporary setting. Therefore, one can say that all preaching must be biblical. Biblical preaching is of such a nature that it includes even so-called "topical sermons," "textua1 sermons," and "expository sermons."

The topical sermon is built around a subject or an idea that does not have any analytical relation to any one passage of scripture. Whitesell says, "In this method the preacher follows a topic or subject as his controlling principle." 1 The question is: Is it right to regard all topical sermons as unbiblical? of course not. Doctrinal sermons, for instance, are usually topical sermons and they can and must be biblical.

Usually a single text does not give the whole truth about a Bible doctrine. The doctrine must become the topic and the whole range of Scripture passages bearing on that doctrine are used to yield up their contributions to that doctrine. In Biblical preaching, doctrinal sermons will go beyond books of

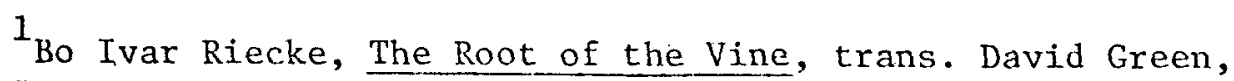
Chapter 7. A Synopsis of Early Christian Preaching. Edited by Anton Fridricksen (Westminster: Dacre Press, 1968), pp. 128-129.

2 Whitesel1, The Art of Biblical Preaching, p. 39.

${ }^{3}$ Ibid., p. 44 . 
theology and deal directly with what the Scriptures themselves have to say. 1

In this type of sermon, the message is derived from and strongly supported by scriptural references and facts.

The textual sermon will be a biblical sermon because "the main theme and major sermon divisions come from the text. The thought of the sermon must always be consonant with the text." ${ }^{2}$ In this form of preaching there is a danger of reading one's own idea into the text if the whole purpose of the longer passage is ignored. This leads to misuse of the text. The text is not understood contextua11y and interpreted accordingly.

Expository preaching seems to be the favorite method for biblical preachers. Whitesell says, "It. . seeks to find and apply the true granmatical-historical-contextual meaning. ${ }^{3}$. This type of preaching takes some hard thinking and careful readjng. Unless the preacher really studies his Bible and his congregation, the sermon may become very dry, lifeless, and irrelevant--a commentary on the text, verse by verse. Unless he keeps the actual congregation always in his mind, the preacher is not able to give the message to them in a clear, simple, and meaningful way.

\section{It should handle aright the word of truth. In biblical} preaching the preacher should interpret or translate the biblical message to man in his age. This task is not an easy one.

${ }^{1}$ Ibid., p. 45 .

2 Baumann, An Introduction to Contemporary Preaching, p. 102. ${ }^{3}$ Whitese11, The Art of Biblical Preaching, p. 51. 
How is the man in the pulpit to make meaningful a heterogeneous collection of ancient documents to a man living in the age of the "electric light and wireless," scientific technology, massed populations, impersonal pressures, and the like? 1

There are at least three stages that should be considered iff the word of truth is to be handled correctly: Exegesis, Exposition, and Application. Each of these shall be briefly mentioned here:

Exegesis. H. C. Brown calls this stage "discovering the 'then' of Scripture." He explains that

Through the use of the critical method of Biblical study the preacher will discover the original meaning of his text. Apart from the natural, grammatical, and historical meaning of a passage, the minister cannot preach authentic Biblical sermons. 2

This means that the preacher's first duty is to find out what the text meant to its writer and what the writer intended it to mean to his first readers.

Exposition. Heinrich Ott refers to this stage as a hermeneutical axch which helps to explain the interrelation between theology and preaching. ${ }^{3}$ This stage is a bridge between the past scriptural event and the present application of it to contemporary man. "The central concern of preaching is so to rehearse the story of God's redeeming action in Christ that this becomes a living reality in the act of preaching." 4 "This exposition is the task of discovering

\section{$1_{\text {Rudolph Bultmann, Kerygma and Myth (New York: Charles }}$} Scribner's Sons, 1958), p. 5.

${ }^{2}$ Brown, A Quest for Reformation in Preaching, p. 51.

3 Heinrich Ott, Theology and Preaching (Philadelphia: Westminster Press, 1965), p. 19.

\footnotetext{
"Miller, The Way to Biblical Preaching, pp. 13, 14.
} 
what in the text stands for all time. What is always true of God and His work among men?"1

Application. This is the stage of "discovering the 'now' of Scripture." H. C. Brown believes that

there must be a present-tense message in Scripture which confronts each hearer as he 1istens. This present-tense message is the "now," the eternal reality of God's message. To be valid, this "now" must be based on the historical message. 2

People are not much interested in the kind of preaching which spends excessive time clarifying the text but sheds no light on the present realities of life. Biblical preaching is essentially relevant and, according to H. Grady. Davis, it is "always in the present tense." 3

This leads us to what James Cleland says:

There are always two centers of jnterest in a sound sermon-the historic faith and the present day. Which is more important? The answer is: which focus is more important in drawing an ellipse? Both are indispensable. Together they form the word of God. 4

In conclusion, a quote from H. C. Brown summarizes well what

has been emphasized above;

Since the only authentic document for authoritative content about God in personal revelation is the Bible, the task of the preacher is to use the Bible correctly in sermon preparation and delivery. To the degree that the minister trusts the Bible to be accurate and authentic, to the degree that he listens to the Holy Spirit while engaged in interpreting the Bible, to the degree that God's self-revelation

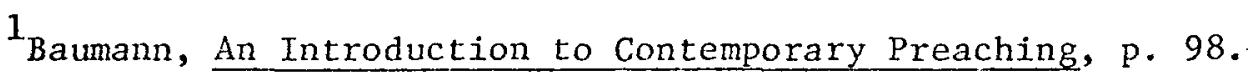

2 Brown, A Quest for Reformation in Preaching, p. 51.

3 H. Grady Davis, Design for Preaching (Philadelphia: Fortress Press, 1958), p. 203.

${ }^{4}$ James Cleland, Preaching to be Understood (New York: Abingdon Press, 1965), p. 43 . 
is "built" into the sermon, to the degree that the minister. preaches his "Biblical sermon" under the leadership of the Holy Spirit, the message is authentic and authoritative. . . Preaching should be an extension of God's revelation from the Bible to the sermon to the people. When this ideal is achieved, the minister preaches with authentic Biblical authority. 1

Therefore, biblical preaching is faithful to the revealed truth of the Bible. It has the same living message as the Bible has for men. It is empowered by the same living Spirit as that of the Bible. And it is presented in a Christlike spirit and manner--with love to man.

\section{The Values of Biblical Preaching}

It is the deep conviction of $\mathrm{H}$. H. Farmer that

only Biblical preaching, preaching based on the continuous study of the Bible with all the help that modern scholarship can give, is the least likely to be, not a trickle of water over desert stones, quickly dried up, but a broad, enduring river which reflects heaven and fertilizes the fields. 2

While biblical preaching is difficult and requires careful study and thinking, it brings more advantages to both the people and the preacher than any other type of preaching. Some of these advantages are considered briefly.

Food for the people. Biblical preaching encourages people to read the Bible intelligently. "Almost every worshipper has a desire to know more about the Bible and will gladly hear the man who can impart a better understanding of the Book of Books." ${ }^{3}$ If the Bible message is vividly presented in an interesting and stimulating manner from the pulpit, people learn how to enjoy reading the Bible

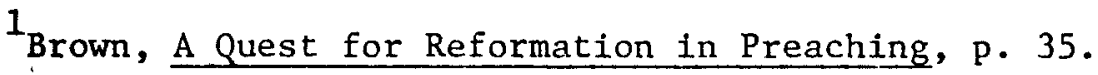

2 Farmer, The Servant of the Word, p. 105.

Whitese11, The Art of Biblical Preaching, p. 25. 
at home. This will help them to have a better acquaintance with the Bible and will enable them to grow in knowledge and in grace. "When God's people learn what the Book says about religion and life, they feel a strong desire to do God's holy will."1 The more of the Bible that people know, the better Christians they are likely to be. They are built upon the solid foundations of truth. As they are fed by the word of God, pecple are strengthened by the power of God to stand the stress and problem of modern 1ife. Whitesell says:

This preaching supplies the proper spiritual vitamins for all saints--for the babes in Christ, the milk of the word; and for mature Christians, strong meat... . [It] developes character, weans from the love of the world, creates love for God and men, sets the affections on things above where Christ is, gives understanding of the providential dealings of God, and generates all profitable forms of Christian service. ${ }^{2}$

It seems, that the most urgent need for today is a revival of biblical preaching if there are to be more strong, fruitful Christians.

\section{Growth for the preacher. Biblical preaching has equally}

practical advantages for the preacher. Since it gives a unique authority to the proclamation of the truth, the preacher has confidence in the message he presents.

This preaching gives the preacher a sense of authority. Authority is inherent in truth, and because the Biblical preacher is conscious of dealing with divine truth, the ring of authority comes into his preaching. 3

He is declaring the authoritative word of God..

${ }^{1}$ A. W. Blackwood, Preaching from the Bible (New York: Abingdon Press, 1941), p. 219.

2Whitesel1, The Art of Biblical Preaching, pp. 25, 26. 3 Ibid., p. 29 . 
This kind of preaching, therefore, demands that the minister should master his Bible. People expect him to know the Bible above all other books. He should be an expert in the interpretation and application of the Bible. Thus as he daily studies the word, he feeds his own soul and brings his own life constantly under the influence of God's word.

Blackwood says, "This habit of preaching from the Bible prevents needless waste of time and energy in searching for texts and topics."I This is another advantage for the biblical preacher. The Bible supplies abundant sermon materials for him. Miller adds:

Give a Bible to the man who knows how to use it, plus the basic tools necessary for the study of it, and no occasion will find him wanting for a sermon theme or the material to develop it. In an unbelievable way, this treasure of sermon material, instead of decreasing and being consumed, increases with use, and, like the widow's cruse, multiples itself as it is drawn upon. ${ }^{2}$

No preacher has ever used up the resources of the Bible. The more one takes from it, the more there remains to be used.

This kind of preaching also encourages the preacher to plan all his work for the pulpit. Biblical truth is so marvelous, so inspiring, that every sincere preacher will set it forth with his best presentation. Thus a better quality of sermon is preached. "Preaching the Bible brings the highest joy to the preacher, and does the most good for the hearers." 3 If this is what Biblical preaching is and

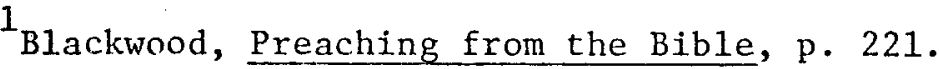

2 Miller, Fire, p. 89.

${ }^{3}$ Whitese11, The Art of Biblical Preaching, p. 160.
} 
what it does, one should take the admonition of Paul seriously to "Preach the word, be urgent in season and out of season. . ." (2 Ti 4:2). 
CHAPTER III

AN ANALYTICAL STUDY OF ADVENTIST PREACHING IN TAIWAN

The primary purpose of this chapter is to attempt to understand the preaching situation of the Seventh-day Adventist Church in Taiwan today. A collection of twenty-two sermons from seventeen. preachers in Taiwan will be analyzed. (One sermon each from twelve preachers and two sermons each from five preachers will be analyzed.) These are current sermons preached in the local churches at the time of the regular Sabbath worship service. A brief background of the preacher, the church setting, and a synopsis of the sermon will be given before the sermon is analyzed. ${ }^{2}$

There are fifteen organized churches and four companies in the Taiwan Plain Mission. (Taiwan is divided into two missions under the South China Island Union: the Plain Mission and the Mountain Mission.) Most Seventh-day Adventist church members are from the middle or lower middle class and about eighty per cent of them are

${ }^{1}$ upon completion of this study the writer felt it would be profitable to include an analysis of one of his own sermons preached in Taiwan prior to his work on this project. A translation of this sermon and its analysis appears as Number 23 in this chapter.

${ }^{2}$ It is recognized that rather than a synopsis, a complete translation of the sermon would be ideal but limitations of space do not allow this. However it was decided to translate sermon No. 8 in its entirety and this appears as Appendix A. By consulting this sermon the reader may check the writer's synopsis of the sermon against the actual sermon itself. 
from a non-Christian background. They are first generation Christians who have had their first Christian contact through an evangelistic effort, a Voice of Prophecy Bible correspondence course, or one of two Seventh-day Adventist institutions--a hospital or a school.

These preachers are from three djfferent cultures and social backgrounds: three, who have graduate degrees, are missionaries from the United States; seven are from Mainland China; and the other seven and Taiwanese. All but one have a college education. Their religious backgrounds also vary; there are seven who come from Christian backgrounds or homes and ten who originally come from non-Christian backgrounds. Due to their peculiar doctrines, Adventists are generally not welcomed in the society of Taiwan. Their religious convictions keep them from working on Saturday. Whether their employers are personnel managers or school principals this causes inconvenience. Their eating habits (i.e., abstaining from eating pork or any meat) causes embarrassment or even unhappiness in many non-Adventist homes. However, they are known as Bible Christians in the island. That means that they value their Bible doctrines and know their Bibles reasonably well.

The major focal point for these sermon analyses will be to see how each sermon is related to the Bible and is adapted to the congregation and the occasion. On the basis of the discussion in the previous chapters, it is the writer's strong conviction that the only right a preacher has to stand in a pulpit before a congregation to proclaim to them the living word of God is that he makes a conscientious effort to present what he has found in the 
Bible. Kermit J. Nord has emphasized this point by saying, "To preach a sermon is to implant the Word of God in the lives of the congregation. . . No sermon is worth preaching unless it is Biblical in its thought and source." 1

Donald G. Miller adds, "All true preaching, whatever its homiletic form, ought to do what Webstex's New International Dictionary gives as the meaning of the word 'expound'--'to lay open the meaning of' the Word of God in the Bible." ${ }^{2}$ Miller concludes:

The Bible is the unique record of the unique Act which creates, sustains, and controls the life of the church, and is as final and unrepeatable as that Act because it is really a part of the Act. If, then, preaching is to reproduce the effects of that Act in human lives now, it can normally do this only by so rooting itself in the Bible that the Deed there recorded is transfigured into living reality now. ${ }^{3}$

It is this writer's particular concern that the pages of the Bible should be opened up again to the twentieth century through the sermon. This means that preaching should confront modern man with the gospel based on the Bible and show its claim upon him to respond to God's call in Christ. Out of consideration of what was mentioned above, the following criteria are suggested for the analysis of these sermons:

1. In true preaching the Bible should be the primary source. The main source of the sermon idea should come from the Bible text, and the text also should control the thought of the sermon.

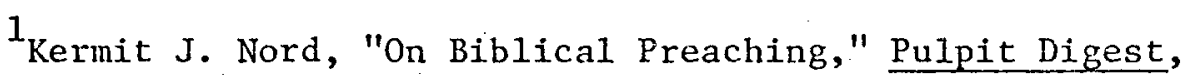
April 1959, p. 17.

${ }^{2}$ Miller, The Way to Biblical Preaching, p. 36.

3 Miller, Fire in Thy Mouth, p. 61. 
2. The sermon should contain the essential message of the Gospel. It should witness to God's gracious redemptive act in Christ.

3. The sermon should show the correct presentation of the original meaning and intention of the. Scripture, that is, the contextual-historical meaning of a scriptural passage. The treatment of the text should be sound. 1

4. The sermon should be parallel, harmonious, and correlative with the text. It should make a serious effort to explain, illustrate, and apply the text.

5. The sermon should be directed to meet the needs of contemporary life. There should be a direct relationship existing between the message and the lives of the hearers. The message should help them solve their problems, live a better life, and confirm their faith. The message should be in modern thought-forms and understandable language. The preacher should bring the message down to the here and now, that is, it shows a man how the message bears on his life. True preaching should call contemporary life back to the standard of biblical faith.

$1_{H}$. C. Brown has identified degrees or levels of biblical authority which are very helpful in understanding authentic preaching. (However, most of the sermons we are about to study can not be classified according to this method.) He has classified the sermons in five groups according to authority: see his book A Quest for Reformation in Preaching (Waco, Texas: Word Books, 1968), pp. 36, 37. 
Sermon Number 1

Preacher

The pastor who gave this sermon has been in the ministry for six years and is the pastor of the Taiwan Bible School. Most of his work has been in the Taiwan Bible School as a Bible teacher. He graduated fron Taiwan Missionary College with a major in religion. He is in his early thirties.

Setting

The audience for this Sabbath morning is about one hundred in number and is mainly composed of students and faculty members from the school. The ages of the students are between fourteen and twenty. They are all dormitory students from both rural and urban areas. Eighty-five per cent of them are from Adventist homes.

\section{Synopsis}

Many miracles of Jesus were wrought at the request of those people who were in desperate need. Mark, in chapter 10:46-52, records the healing of a blind beggar, Bartimaeus, who sat by the roadside asking for hel.p from passersby. We have many beggars and blind men like Bartimaeus in our church today. The real picture of our conditions today are depicted in Rev 3:17. We say that we are God's remnant and that we have more light than others, yet we do not realize that the gods of this world have blinded us. We would become the most miserable people if our hope were built on this life only (1 Cor 15:19). Blind Bartimaeus in his wretched state of no hope for the future sought for help. When he heard that Jesus was 
walking by, he cried out, "Son of David, have mercy on me!" Regardless of scorn and ridicule, he cried out all the more until he was called by Jesus. Nothing can separate us from the love of God. When Jesus called hin, Bartimaeus threw off his mantle, sprang up, and came to Jesus (Mk 10:50). His mantle was all he had. A rich young ruler went away sorrowful when Jesus told him to sell all that he had and give to the poor and then follow Him (Mk 10:17-22). Jesus said to the disciples: "If you would follow me, deny self. . ." (Lk 9:23). Our only goal while at the school is to learn how to deny ourselves and follow Him. Bartimaeus knew how and he did it. "Master, let me receive my sight" (Mk 10:51). Do you have the same faith?

The Use of the Bible in the Sermon

The sermon is based on a miracle of Tesus recorded in the Scripture. A brief description of the background of the passage is given and the natural and historical meanings of the text followed. The main source of the sermon ideas are from the Scripture, and the thought of the sermon is controlled by the text. Though the text is not explained in any detail, the central idea of the text does not seem to be distorted.

Besides the main text, four other texts are read or referred to to support the ideas of the sermon. An illustration from a Bible incident and one from a pastor's experience adds some light to the sermon idea. However, the text itself is not explained more clearly and the complete idea of the text is not included. Therefore, when it comes to the application of the message, a general spiritual 
lesson is given. For instance, the statement is made, "Let us learn from the faith of Batimaeus and our spiritual sight will be opened to see the truth." The students making up the congregation need something more specifically related to their living experience than just a general spiritual exhortation. Nevertheless, the comparison made between our spiritual condition and Bartimaeus' state is very helpful in pointing out our spiritual need.

The love of God could be manifested more clearly in the message, if Jesus' special attention to the insignificant blind beggar were mentioned: Jesus in pity touched his eyes (Mt 20:34). As to its relevancy, the lives of the congregation are brought into the sermon several iimes. Nevertheless, it might be hard for the young people to see what the message has to do with their lives since there are no practical applications, just general moral exhortations. The language is simple and can be easily understood. 


\section{Sermon Number 2}

\section{Preacher}

The preacher is an administrator and has been in the ministry for more than fifteen years. He received his college education at Taiwan Missionary College and has filled various positions in the Union as well as the local mission. He is in his early forties.

\section{Setting}

The church located near the union mission since 1955 is in a large city. The congregation is composed of a complex group: families of Adventist workers, nursing students, hospital employees, patients, and some members and believers from the city. The regular church attendance is between 250 and 300 .

\section{Synopsis}

The subject of the sermon is announced at the beginning: "Putting On Jesus." God loves the beautiful; so do His created children. Man attempted to change his beauty and marred himself. Nevertheless, God desired all His children to be beautiful (Is 4:2). Those who put on Christ become beautiful. Baptism is a "putting on" of Christ (Gal 3:27). By putting on the "Christian uniform" we can represent the beauty of Christ. Christ gave us his robe of righteousness to wear (Is $61: 10$ ). God wants to clothe us with His righteousness (Job 29:14). However, people do not want God's righteousness. The true Christian is to put on Christ and His righteousness, to be Christlike, and to do the work of Christ. The Christian should not be willing to put on any other name but Christ's name. 
The Use of the Bible in the Sermon

This sermon uses four texts from the bible and five quotations from the writings of E. G. White. The framework of the sermon and ideas presented in general are scriptural, but the sermon presents only a vague interpretation of the text. The theme, which is a phrase of the text in Gal: $3: 27$, controls the thought of the sermon, although the text is merely read without any further exegesis. The context of the Scripture is not clear, and the text is not expounded. The original meaning of the text did not come out clearly enough for the congregation to grasp its vital message. This text, Gal 3:27, is important. Baptism is a "putting on" of Christ, a "clothing oneself" with Christ. This metaphor needs to be explained. The use made of E. G. White's writings was to explain some of the meaning of the text and to support the sermon idea. The central meaning of the text could come out stronger and clearer if the correct explanation of it were given. The use of the texts is merely in support of the Christian ideas which the preacher is trying to convey. The partial meaning of each text is mentioned without including the complete central meaning of the text. All texts, including the main text, are used out of context. In the context of Gal 3:27, Paul sums up the full achievement of the gospel. The law was the essential forerunner to faith. The main emphasis of the context here did not state the importance of "putting on" Christ, while this sermon did. The name of Christ is referred to quite often in the sermon, but the redemptive act of God is not mentioned. Being a sermon related to Christian living, the congregation is exhorted to take Jesus' name as their name. 
The practical application of the message is not given, though the sermon deals with the practical subject: "Christian Living." The sermon does not help meet the difficulties of the hearers, nor answer their questions, nor confirm their faith. The illustration at the end of the sermon is interesting and personal since it is the preacher's own experience, but it does not inspire the congregation to renew their dedication and consecration. This is a topical sermon based on a biblical idea. 
Sermon Number. 3

$\underline{\text { Preacher }}$

The preacher has been pastor of this church for four years. He became a Seventh-day Adventist in his mid-thirties and has been in the ministry since then. He already had some Junior College education before studying in Taiwan Missionary College for a little over a year. He is in his mid-fifties.

\section{Setting}

This church is the second oldest Adventist church in Taiwan, and it is located in a city which used to be a cultural center for the whole island. The members of this church come from all walks of Iife, and the majority of them belong to the lower middle class. The toial church membership is two hundred, however, only about half of them are regular attendants at the church.

\section{Synopsis}

In spite of the genius of diplomat. Dr. Kissenger and his many successes in foreign affairs, the world is still in great turmoil. The signs of the second coming of Christ around the world warn us that His return is at the door. What is the admonition of Jesus: (Mt 24:44, 45). The most important task for Christians today is preparing for the Lord's return. Many think that all we should do is to get ourselves ready and wait for His appearing. But Jesus says in Mt 24:45 that the faithful and wise servant gives his household food at the proper time. Therefore, to hasten His return we should be ready and also be helping others to be ready. Each has his part to play while 
waiting. Everyone is sent by God to be His witness (Acts 1:8). Adventists can discern the signs of the times. Many people are still ignorant as to what these signs mean. What are we doing to help them?

The Use of the Bible in the Sermon

The second advent and the signs of Christ's coming are timely biblical messages. The main idea of the sermon is found in Mt 24:44, 45 . But there are not sufficient supporting texts to establish a solid foundation for the discourse. It is quite possible that the pastor takes for granted that the congregation is already familiar with this doctrine. In addition to the main text, only one other text is used in the whole sermon to support the idea presented. The immediate context of the main text is not examined: while verse 44 belongs to "the watchful householder" (Mt 24:42-44), verse 45 is on the thought of "the faithful and wise steward" (Mt 24:45-51). The preacher may have been too eager to stress his main point, namely, that each has his part to play in the hastening of Jesus' coming, so that the text itself is not examined but given only a surface explanation. The illustration from a current event--the visit of the president of Executive Yuan to their nearby town--is fresh and pertinent to the sermon idea since all church members were aware of the happening. In spite of this good biblical theme, the content is not as strongly Christ-centered as might be expected: how Christ Jesus can help us in the preparation for His second coming is not mentioned. The significance of the faithful and wise servant who was appointed by his master to supervise the household was ignored in the sermon. From the sermon one learns that this church is in the middle of an 
evangelistic effort, so the message really fits the time and occasion to inspire the congregation to re-examine their own hearts and concern for other people's salvation. Nevertheless, the sermon is not based on the Bible texts deeply enough to be convincing or to be called a direct biblical sermon. 
Sermon Number 4

Preacher

The preacher is a graduate of Taiwan Missionary College and has been an Adventist minister for more than twelve years. He is in his late forties. Although his work is connected mainly with the publishing house, he is an elder and a regular speaker for this particular church.

Setting

The church located near the Taiwan Adventist Hospital for twenty years is in a large city. The congregation, including both young and old members, consists of over 250 people with different backgrounds. About one half of the congregation are denominational employees.

\section{Synopsis}

People tend to put their hope in the future (Jer $8: 20$ ). The Corinthian church was an immoral church and had many problems, yet Paul rejoiced in the change that had taken place (2 Cor 7:5-16). If even the Corinthian church could be changed, then there is still more hope for us. How did they experience this revival? A godly grief produced a repentance that led to salvation and brought no regret. This is demonstrated by Paul's experience on the way to Damascus (Acts 9). Jesus told the disciples, "Let not your hearts be troubled" (Jn 14:1), but He also said, "You will be sorrowful, but your sorrow will be turned into joy ( $\mathrm{Jn}_{\mathrm{n}} 16: 20$ ). We need a pastor who will make us sorry after a godly manner just like Paul did for the Corinthian 
church. The Laodician church, in her lukewarm state, could not see her own need but was filled with pseudo-peace. What are the evidences of having repented? True repentance produced earnestness, eagerness to clear themselves, indignation, fear, longing, zeal and punishment (2 Cor. 7:11). Earnestness in Bible study, prayer, and witness is an evidence. Avoid laziness (Jer. 48:10). Our motive for diligence should be love, not fear of punishment. Godly fear is another evidence of repentance. God promised to look after those who tremble at His word (Is 66:2). Punishment is also an evidence of repentance. For church revival, we need to uphold the standards of the church. Jesus stands at the door of every heart and church awaiting our response (Rev. 3:20). The promise is that Jesus loved the church and gave Himself up for her to cleanse her that she might be holy and without blemish (Eph. 5:25-27).

The Use of the Bible in the Sermon

This sermon is loaded with Bible texts and biblical ideas.

The main source for the sermon idea is found in 2 Cor. 7:5-i6 and special attention is focused on verses ten and eleven. The background for this passage is not mentioned--Paul spoke of the coming of Titus. He was much pleased at the tidings Titus brought, namely, that the sinful had become penitent. With a very brief description of the Corinthian church, the whole passage is read, but the immediate context is not explained. In the first division of the sermon body, the definition of "godly grief" is clearly explained-and compared with "worldly grief." But in the second division which is based on 
yerse.11, the complete idea of the text is not included. The pastor mentions only three results of godly grief, while Paul stated seven of them. Why only these three are referred to is not clear. The use of Jer 48:10 in connection with "earnestness" in 2 Cor 7:11 was a sort of side-track. It does not give any support nor an explanation for 2 Cor $7: 11$ at a11. This is a misuse of an additional scriptural text. In the last division the picture of Jesus came in quite clearly through the quoting of Eph 5:25-27 regarding what Jesus had done for the church and His invitation- to the Church (Rev 3).

There is a direct relation between the message and the church as a whole since it deals with church revival, but it is not related to personal experience which is very important for church revival. Bible study, prayer, and witness are merely mentioned. The sermon exhortation does not come to the congregation in a very specific way; it is only general when the sermon concludes: "May God help us, make us sorry after a godly manner so that when he comes we might be hoiy and without blemish to meet Him."

Although the sermon is loaded with biblical materials, the use of this main passage for this particular purpose in the sermon is different from the original intention of this passage. The direct biblical sermon should utilize the same purpose, intention, or objective as the biblical passage. 
Sermon Number 5

Preacher

The preacher is in his early forties, has graduated from Taiwan Missionary College, and has been in pastoral work for more than twelve years, main1y in a rural church.

\section{Setting}

This is a newly built church located on the mission office campus. The congregation totals about thirty-five and is composed of Mission Office employees' families and some twenty members from the town.

\section{Synopsis}

"Consider your ways" (Hag 1:5). God's prophet Haggai told Israel to examine their conduct. The year after the people had returned from the exile work on the temple had begun; but now the people were discouraged. The prophet cries out against the prevalent idea that God's work is of secondary importance and must await economic solution. We Christians need to examine our ways of living: Do we bear good fruit in our daily living? (Mt $7: 19$ ). Some of us have been Christians for many years but have never borne any fruit in our Christian 1ives. Some Christians are 1ike chaff (Mt 3:12). Outwardly they call themselves Christians but in reality they do not have faith. They are like the chaff, easily driven away when the wind of temptation comes; some are like an old wine skin (Mt 9:17). Do I still. live an old life so that my friends do not know whether I am a Christian or not? Some are lukewarm Christians (Rev 3:16). 
A lukewarm Christian will bring harm to the growth of the church. Do I belong to the group of five foolish maidens who did not prepare extra oil while they were waiting for the bridegroom (Mt 25:7, 8)? We a11 need to examine our faith and life from time to time. God expects us to be good Christians. He wants us to have abundant life on this earth and He wants to save us for His kingdom.

The Use of the Bible in the Sermon

This sermon consists of six texts with Hag 1:5 being the introduction and five texts from the New Testament being the body of the sermon. The preacher based his sermon on these scriptures, but they are not related in any way except that they are applicable to Christian 1iving. Haggai 1:5, "Consider that your way of life," was used as a springboard for the sermon, and though the background of the text was briefly mentioned, it had nothing to do with the five texts in the body of the sermon. These five texts were chosen to support the idea the preacher sought to convey. They are wel1-chosen texts and each has a good lesson for Christian living. In spite of the context of these texts being completely ignored, some of the explanations carried the correct meaning and intention of the scripture, but others failed to do so. For instance, the preacher interpreted the old wine skin of Mt 9:17 as "old life." This is not the original meaning of the Bible text and is not intended to be understood as such. However, to interpret the old wine skin as "old life" fits the sermon idea. By doing this the preacher is putting his own idea into the text. 
The "good news" is not proclaimed except at the conclusion when the preacher mentions that because of God's love, He expects His children to have abundant life and be saved for the kingdom. The message does not relate to Christ at all. It is a discussion that treats a subject but does not deliver the "good news." The sermon misses the mark of biblical preaching.

As to its relevancy, the preacher is attempting to show the relation between the text and his audience. After a brief explanation of each text, he applies the sermon idea to each individual in the congregation by asking personal questions, such as: Do I become the obstacle to the progress of the gospel because of my lukewarm state in Christian living? Do I really want to see Jesus' coming soon? The message is suitable for the whole congregation since it gives five ways of examining their Christian lives. Surely none of them will miss all of these ways and say none of the ideas apply to them.

The preacher presents his message in a language that people can comprehend. It is a language that arises out of the experiences in which they have participated--the illustration of a rotten orange in a basket and burning chaff cone from the daily experience of the congregation. Since there are many orange markets in that town, they know how a rotten orange can spoil a whole basket of oranges. The purpose of the sermon is to strengthen the Christian conduct, but the way of handling the texts offers less biblical strength and the sermon possesses a weak scriptural foundation. 


\section{Sermon Number 6}

Preacher

The preacher is a missionary, graduated from Andrews

University with a B.D. He has been in Taiwan for over five years. He is in his early thirties. The first two years he spent his time learning Chinese, and for the past three years he has been serving as church pastor for the oldest Seventh-day Adventist Church in Taiwan. The sermon was given in Chinese.

Setting

The church is located in the capital city of Taiwan. It has a membership of over three hundred and the regular church attendance is about one hundred and twenty members.

Synopsis

Seventh-day Adventists like the subject of temperance because they do not smoke nor drink. However, temperance does not cover smoking or drinking alone, it defines a broader spectrum. A wrong concept of temperance is quite common among Seventh-day Adventists. Why do we promote true temperance? The discoveries of science tell us that what affects our bodies will also affect our mind. I should not do anything that could cause damage to my mind and to my relationship to God. Doubt, criticism, and the love of the world will not allow God to come into my heart and work His plan in me. How can I be temperate? Paul knows the secret of it (Rom 12:1-2). He is a great promoter of temperance ( 1 Cor 9:25). By love, present your body as a living sacrifice. This is a continuous presentation 
(Lk 2:23). To live for Christ is harder than to die for the Lord. Due to our own needs we ask God to accept us and change our hearts according to His will. This has to be done by our own willingness. "Present your bodies" means all of us including the mind. It is our adoring response to God, of whose mercies we are aware. God wants a living sacrifice. Therefore temperance is a "must." It is not only acceptable to God but is also our reasonable service. There is no merit within us. As we continually do this, our mind is renewed. As a result we no longer have the desire to be conformed to this world. This is the work which Christ has promised to do for us. Thus we can begin our heavenly life while on this earth. Temperance is a fruit of the Spirit (Ga1 5:22). If we are temperate, the Spirit will live in our hearts. Let us make a covenant with God today. The yielding of the life in holy living is well pleasing to God.

The Use of the Bible in the Sermon

It is obvious that the sermon idea came from Rom $12: 1-2$, and the text controls the theme of the sermon. There are some indications that the preacher tried to merge this text with his sermon very closely. The original meaning of the text came out quite clearly and the correct interpretation of the intention of the Scripture was revealed. However, the context of the passage is not mentioned: Paul has completed the doctrinal section of the letter dealing with principles and problems. He has set forth how to be in harmony with God's will and now he seeks to explain the life of faith in practice and to impress on his readers the 
duty of Christian living. The sermon has explained and applied the text and they correlate with each other. The key words and phrases of the passage are dealt with clearly in relation to his sermon idea without distorting the meaning of the text. The use of I Cor 9:25; Lk 9:23; and Gal 5:22 as subordinate texts is very appropriate.

The gospel of Christ is obviously revealed in the sermon. In the explanation of the living sacrifice which is acceptable to God, the preacher stresses that we do not have to wait until we are holy, He will cleanse us and make us holy. The renewal of the mind is not our work. It is His work. The "good news" is heard here. The message is closely related to the congregation's daily experience. It focuses on the individual Christian, that is, everyone has to present himself to the Lord. The language is plain and his effective use of the first person singular appeals to the personal need. This is a direct biblical sermon though it is based on two verses of the Scriptures. 


\section{Sermon Number 7}

\section{Preacher}

The pastor is a graduate of Taiwan Missionary College. He has been in pastoral work for over ten years in various churches both in the rural and urban areas. He is in his mid-thirties.

\section{Setting}

This is an urban church. The regular church attendance is between 250 to 300 . Most of tho se attending have been Christians for a number of years.

\section{Synopsis}

John $3: 16$ is a unique proclamation of Jesus to the world. It is the best news ever proclaimed. This marvelous gift of love is given to us by God and He expects us to accept it (Rom $8: 32$ ). It was the ruler of the universe who gave us this amazing gift. Because He loved sinners, He gave us this free gift. The most miserable person in the world is a lonely person who cannot love others and cannot be loved by others. The people of this world are the receivers of this love. Every sinner is qualified to receive this love. God gave this gift to us so that we might have everlasting life. Life is a riddle. But if we understand the wonderful love of God, we have the answer to this riddle of life. How can you know you have received this love of God? Your daily Christian living will tell you. How is your Bible study and prayer life? Are you eager to do something for God and others? 
The Use of the Bible in the Sermon

The preacher is trying to expound the truth revealed in In 3:16. The whole sermon is based on this great text of the Bible. But the background and context of the text are completely ignored. His concern was just to analyze the truth contained in the text and to show the love of God. The sermon gives the original meaning of the text, and the sermon and text are harmonious and closely related. While the whole Bible is an exposition of this text, the preacher used only one additional text in the sermon to support the idea. He could have used more texts to make the message vivid and appealing. No doubt the essential message of the gospel was mentioned--God loves sinners. The message involves the whole congregation and invites them to accept the gift. It is related to 1ife in general and exhorts man to live a better life. Nevertheless, the application of the message to the congregation lacks concreteness and does not appeal to the listener personally. For instance, he says, "If you understand the wonderful love of God, you will have an answer to the riddle of life." What does he mean by this? He does not give any further explanation. The action of God's love in the past is mentioned, but how this love comes to affect the hearers' present lives is not clear in the sermon. He treats the text in a mechanical way: God--the giver; sinners--the receivers; love--the motive; eternal life--the purpose. But the explanation of these Ideas is not persuasive and interesting. Though the message of the text is self-explanatory, this great truth needs some additional blblical material and present day incidents to make it alive and dynamic. 


\section{Sermon Nuinber 8}

\section{Preacher}

This preacher is a graduate of Taiwan Missionary College and is currently serving as a Bible teacher at the Taiwan Bible School. Before accepting this responsibility, he was a pastor for a period of five years in a rural church. He came from a Presbyterian background and has been in the ministry for almost ten years. He is in his early thirties.

\section{Setting}

The sermon was presented in a school church on a Sabbath day. The congregation consisted of eighty students, ten teachers and their families. The students, between ages fourteen to twenty, are from both rural and urban areas. Eighty-five per cent of them are from Adventist homes.

\section{Synopsis}

The fear of the Lord is the beginning of wisdom $(\operatorname{Pr} 9: 10)$. The fear of the Lord is the greatest need of mankind. True wisdom leads man to fear God. Christian character is formed as a result of fearing God. To fear God will keep you from sin (Ex 20:20). Abraham did not hold back from offering his only son to God because he feared Him (Gn 22:11, 12). God commanded Job to be a perfect and an upright man who feared Him (Job 1:8). Satan knows that as long as a Christian does not fear God, his Christian character will be lost. God requests us to fear Him and walk in all His ways. (Dt 10:12). Both Paul and Peter advised us to fear God (2 Cor 
$7: 1 ; 1 \mathrm{Pe} 1: 17$ ). In God's kingdom everyone fears Him (Rev 19:5). of course, there are many reasons that we should fear the Lord. Above a11, He is an almighty God (Dt 10:17). As pilgrims on the earth we need to seek after a godly life and fear Him. Let us remember that the fear of the Lord is a fountain of Life; we depart from the snares of death $(\operatorname{Pr} 14: 27)$.

The Use of the Bible in the Sermon

This sermon is a Bible-reading method of exposition, focusing on the topic of fearing God. Instead of concentrating on one passage of scripture and basing the whole sermon idea on it, ten texts are used to develop the sermon theme. All texts are related to the "fear of God." The sermon ideas are biblical since the biblical incidents and statements support the whole sermon. While the background and context of three texts are mentioned with two sentences each, the rest of the sermon texts are only quoted without explanation about their context and background. The exegesis of these texts is not done properly because only the surface meanings of the texts are stated to support the sermon idea. The message is developed loosely without any particular sequence of thought. This can be seen in the order of the ideas being presented. None of them includes the complete idea of the text. Only a portion of the text is used to relate to the main idea. Therefore, the text is not explained in full and the sermon shows a lack of clarity. The meaning of "fearing God" is not explained though it was the pastor's topic. The homiletical structure is not clear either: the sermon starts with a text $(\operatorname{Pr} 9: 10 a)$. Without explanation, it moves to the need for 
fearing God. Then three Biblical incidents are cited only briefly followed by the admonitions from Paul and Peter. One reason for fearing God is stated in the last part of the sermon, and it concludes with an exhortation to fear God. Though this sermon has plenty of biblical facts, yet the explanation, illustration, and application of the texts is very vague.

The elements of the gospel are not found in. the sermon; that is, the "good news" does not stand out in the message. The discourse has treated the topic but does not deliver the "good news." The text is used as pretext for the repetition of a general impression of a Christian point of view--"fear God."

The message is intended to suit the congregation but there is no concrete illustration of the idea or message for the student group. Besides a general exhortation at the close of the sermon, there is no indication of involving the congregation in the sermon. The personal element is lacking. The preacher's use of the personal pronoun is minimal. Instead, some general terms 1ike "Christian" and "man" are used. Nevertheless, he used a simple vocabulary so that even younger students could understand what he said. Obviously it is hard for each listener to see the relationship between the message and his present living experience. 


\section{Sermon Number 9}

$\underline{\text { Preacher }}$

Before becoming the administrator of Taiwan Missionary College and pastor of the College Church this preacher served for a period of two years in an urban church. Prior to that he obtained his M.A. and B.D. from Andrews University and has been serving in Taiwan as a missionary. He is in his mid-thirties.

\section{Setting}

The sermon was preached to the College Church congregation on Sabbath. Taiwan Missionary College had just moved to a rural area. There were about thirty students and five teachers with their families present.

\section{Synopsis}

The mind of man has always imagined for itself a better place than a sin-cursed world. People of this world have many different ideas as to what heaven is like. In 1 Cor $2: 9$ it says it is a place beyond anything that we can comprehend. There will be at least three dis-tinct joys in heaven: the joy of discovery--1 Cor 15:51-54, the discovery of the great improvement of our new bodies and senses, of the increase of our mental capacity, and of the New Jerusalem as it comes into full view (Rev 21); the joy of reunion--the joy of being reunited with our friends and loved ones (Rev 21:4), the unexpected joy and surprise of reunion with those whom we have led to Christ (Lk 15:7); and lastly, the joy of fellowship and communion--communion with those great men of God of the past, the guardian ange1s (Ps 34:7), and above 
a11, with Christ. We also have something to contribute to that fellowship and communion which is of deep importance and interest. Eye has truly not seen, nor has it entered into the heart of man the things, the joys that God has prepared for those who love Him. They will be beyond our fondest hopes.

The Use of the Bible in the Sermon

The sermon is on the subject of "Heaven," based on biblical material and imagination. The suggested three joys of heaven are well grounded in the scripture and each joy is explained and illustrated by biblical materials. An appropriate number of texts are used to establish an authoritative foundation for the sermon. Ordinarily, a single text presents one aspect of the doctrine, so a number of key texts treated in their contextual relationship to give a comprehensive view of the topic must be used. This he did wel1. The sermon shows a correct presentation of the meaning and intention of the texts except for the main or introductory text which is found in 1 Cor 2:9. The preacher's use of 1 Cor 2:9 in his sermon has a different meaning from the main idea of the text in its context. The verse itself centers decisively in Paul's argument that man through his physical senses is not able to understand God's wisdom in the cross of Christ. The use of the additional scripture is mainly to support the idea he is emphasizing. The context of these scriptures are not examined, but the explanations of these scriptures are clearly done through the exposition of Bible incidents and the writings of E. G. White. The sermon has explained and illustrated the main text of the sermon, 1 Cor 2:9. For example, 
In talking about the joy of discovering the change of body at the second adevent, he says that one really cannot begin to imagine at this moment the wonderful changes which will take place in the bodies of the redeemed. In other words, the changes will really be a total surprise to all. Such a surprise will be, of course, a great joy. The sermon has an evangelistic purpose and contains the essential message of the gospel.

The sermon is relevant because it presents the high hope for a better world and meets the deep desire of the congregation. The sermon exhorts the hearers to renew a desire in their hearts and minds to be there. 
Sermon Number 10

Preacher

The preacher who graduated from Taiwan Missionary College five years ago is a young man in his late twenties. He was brought up in an Adventist home and educated in an Adventist school since his elementary education. After his internship, he was transferred to this new church in the city.

\section{Setting}

The church is located in the center of a city. While it has a total membership of two hundred, the regular attendance for the Sabbath service is about eighty. Most of the members have been Christians for many years.

\section{Synopsis}

A great banquet is ready. Many are invited (Lk 14:16-24). The three excuses quoted in verses 18 to 20 show that these people think that they have other better things to do. People today have the same attitude towards the gospel invitation. Jesus warned that as it was in the days of Noah, so.will it be in the days of the Son of man. (Lk $17: 26,30$ ). The parable of a great banquet indicates that many despise the salvation of Christ. Two groups of people are mentioned: the first group, though they were good friends of the householder and were being invited, rejected the invitation; the second group, though they were outcasts and despised, accepted the invitation and were honored by the householder. The people of Israel were chosen as a particular people, but they rejected the gospel and 
nailed Jesus on the cross. The Gentiles are now included in the invitation to the supper of the Lamb. What are our responsibilities as members of God's church? We should be like his servant and go out and give the gospel invitation to people (Mt 28:19). Jesus does not despise any individual. He commands us to work with Him (Rev 22:17). The promise of His abiding presence is with the church that follows the commands of God (Mt 28:20). Before the end of the world, the gospel will be preached throughout the whole world (Mt 24:14). What are we doing for Him?

The Use of the Bible in the Sermon

The preacher uses Lk. $14: 16-24$ as his text for the sermon, but the sermon idea comes only partially from the text. The text is about the parable of the great banquet with emphasis on the people despising the invitation. The preacher bases the first part of the sermon on this text, then he focuses the second part of the sermon on what the servants of the Lord should do, which is not the main idea of the passage; in other words, he leaves his text and gives another sermon on another topic based on four texts from the New Testament. The complete idea of the text is not included. The second part of the sermon might be derived from a thought from the main text which says, "Go out quickly to the streets and lanes of the city, and bring in the poor, the blind, and the 1ame." His intention is to call the attention of the congregation to the fact that servants went out for the Lord's work, which is not the intention of the passage. The sermon misses not only the intention of the text but also the proper exegesis of the passage. In addition, the "good news" is merely referred to in 
the sermon: Jesus is seeking for sinners and is concerned over their salvation. This is a sermon on Christian service. The congregation is exhorted to accept the gospel invitation and to fulfill the responsibility given to each one of them. The message is relevant to the occasion since it was literature evangelism week, and each member was urged to go out to make some contacts for the Lord. 
Sermon Number 11

\section{Preacher}

After graduating from Taiwan Missionary College, this preacher was called to be the pastor of a rural church. He has been an Adventist minister for a total of seven years and presently is in his third church as a pastor. He is in his early thirties.

\section{Setting}

The sermon was preached to a company of eighteen people-eleven of them are Adventists and the rest are new interests. They met in a small hall which can accommodate thirty people.

\section{Synopsis}

An anecdote from the Ching Dynasty of China tells how a renowned calligrapher, Mr. Wang Hsi-Chi, helped an old lady to sell her fans by writing a few Chinese characters on them together with his signature. People bought her fans because of Mr. Wang's signature on them. What is man? He was made of dust and without special value until God breathed into his nostrils the breath of life and he became a valuable living man. Today, men come short of the glory of God because all have sinned (Rom 3:23). Adam disobeyed God's word and became a sinner. As a result man lost his value. Then how can man go back to his original state of being a valuable living man? In Rev $3: 12,13$ it says that by the grace of God man can have a victorious 1ife. If the name of God is written on us we become valuable. Jesus has many new names to write on overcomers (Is 62:2). A new name which the mouth of the Lord shall name. May God help us to be 
overcomers so we may have our new names on us. Remember that there is a new name waiting for each one of us in heaven.

The Use of the Bible in the Sermon

This is a sort of a homily presenting a free-running commentary on a topic--"new name." It is a simple homily developed on an informal pattern. The idea comes from the text and the sermon is arranged according to the preacher's way of thinking. The background of each text is not explained to the congregation. And the exegesis of the texts is not done; the preacher merely comments concerning the text as he sees it related to his topic. For instance, in connection with $\operatorname{Rev} 3: 12,13$, he mentions that the new name will be written on the overcomers, but the meaning of a triple name inscribed on the overcomers is not explained. In other words, not only are the correct meanings of the texts not presented, but the complete idea of the text is not included in the sermon.

The anecdote is an interesting introduction and illustrates the central idea of the message well. The sermon contains the "good news" for the congregation: by the grace of God we can have a victorious life. The sinner has the hope to be rescued from his valueless condition. The preacher gives simple explanations, uses an illustration, and does not confuse his message with too many ideas. This kind of presentation suits the new Adventists and visitors who do not have much biblical knowledge. The anecdote is easily understood by the congregation, but the idea of getting a new name should be explained in further detail since it is a new concept to some of the listeners. 


\section{Sermon Number 12}

Preacher and Setting

See Sermon No. 2 .

Synopsis

"Jesus, our great example," Heb 12:1, 2, could be divided into three statements: Lay aside every weight and sin; Run the race set before us with perseverance; Look up to Jesus the pioneer and perfector of our faith. Sin is a burden which makes us sad, gives us pain, and causes worry. Jesus invites sinners (Mt 11:28-30). He does not force people to carry the yoke. The burden is put on our shoulders by ourselves. Many Christians are troubled by the question where shall we lay our sins: sin gives us fear and we dare not come closer to God. Those who bear the burden of sin will miss God's abundant blessings. On their way to the tomb to see Jesus, Mary and the other ladies worried about who would roll away the stone from the door of the tomb for them, and they missed the beauty of the garden (Mk 16:1-3). Running the heaven1y race requires an effort (Mt 11:12). The Christian hope is the appearing of the Lord. We should look forward. Athletes run the race without looking back in order to win the reward. Pilgrims should persevere and must not be afraid of hardships. By looking up we can be changed to his likeness. Our Christian life fails because so often we look at people or self. We need Christ in us (Gal 4:19). The more we look at Him and know Him, the more we will be like Him. Every Christian has the responsibility to look up to Him and learn of Him. We will be victorious if we look up to Christ daily (Num 21:8,9). 
The Use of the Bible in the Sermon

The sermon is based on Heb. 12:1--2 which is divided into three phases for discussion. The correct meaning of the text is preserved throughout the discourse though the context was not dealt with. The focus of Hebrews, chapter 12, is the application of the faith-principle to life. It is an exhortation unto steadfastness in the Christian life. The exhortation is followed by a lengthy proof of the efficacy of persevering faith to enable its possessors to do God's will. The heroes of faith in chapter 11 become, to the writer, an amphitheater of spectators cheering the Christian runner on toward the goal. The message of the sermon does not quite match the intention of the text which is a continuation of chapter 11 . However, the central idea of the text was not corrupted. The supporting biblical materials for the main text are rather weak and irrelevant. The use of $M k, 16: 1-3$ and $M t$ 11:12 gives no direct support to the main text. They are not explained but are just read. The sermon reaches its climax at the third point where, looking up to Jesus, the pioneer and perfector of our faith is stressed. Gal $4: 19$ is quoted to support the idea, but again it is not interpreted. The third point is illustrated by the incident of Moses lifting a serpent of brass in the wilderness. The use of the imagination of the preacher in regard to this incident is very good. As a whole, the Bible is used as a source for the sermon, and the sermon carries the original meaning of the text. The congregation is exhorted to look up to Jesus. There is a direct relation between the message and the lives of the congregation. The sermon exhorts them to live a better 
1ife, The last illustration of four categories of people in his sermon includes all nembers of the congregation and helps them to see their situation. It helps to make the message relevant to the present congregation. This is a biblical sermon though the use of additional biblical materials could be improved. 


\section{Sermon Number 13}

Preacher and Setting

See Sermon Number 3 .

\section{Synopsis:}

"Living with Jesus." Jesus became flesh and dwelt among people to seek the lost sinners and to die for them in order to redeem them. The purpose of the incarnation was not just to die for us but also to li.ve for us that we may know the secret of a victorious life. We should learn how to follow His example in our daily life. John 5:30 tells us that Jesus totally depended on God. His miracles were performed by faith in God and prayer (Jn 14:10). Lazarus' resurrection was a good example of this. (Jn 15:5; 2 Cor 5:17; Col 1:27; Eph 3:17.) Jesus is our mediator through His divinity and humanity. Thus man can reunite with God. If we live with Christ, we should live like Jesus did--as God is in Him and He is in God. Sin separates us from God, so sin has to be taken away in order for us to live in Christ. Sin is unbelief (Rom 14:23). Man's fall at Eden was caused by Eve's unbelief. Jesus' total dependence on God instead of Himself should be our example. By God's grace we can live with Christ.

The Use of the Bible in the Sermon

The sermon is a little bit overpacked with biblical texts and facts. The Bible texts and illustrations are all well chosen to unfold the message. It is hard to tell which is the main text since there is no particular text that stands out in the sermon. 
His, sermon thoughts are biblical and are supported by the texts, but none of the texts are properly explained or interpreted. They are quoted or merely referred to. The meaning of each text needs to come out clearer so that the message can be strengthened. The outline is hard to follow: the first part of the sermon body employs many texts and the preacher merely reads them, so that the congregation has to figure out the reasons for using the texts and their connection to the idea. For the second half of the sermon, only one text is read but many biblical facts are referred to in order to explain the idea. It is obvious that the sermon has a close relationship with the Bible and the message is a vital biblical message. Nevertheless, the application of the message is general and vague since only an exhortation is given that we should live in Christ and should never depend on our own strength. The plan of salvation is quite plain in the message and the relationship of Christ to our Christian living is stressed. This is a Bible-reading method of preaching focusing on the topic itself. The relation of the sermon and the text is not clear, though the topic is related to the congregation's daily living. 


\section{Sermon Number 14}

\section{Preacher}

This young missionary has completed two years of the Chinese language course and has been serving as a pastor in a city church for the past two years. He is in his early thirties. He is a graduate of Andrews University with a Master of Divinity degree.

\section{Setting}

This city church has a membership of two hundred but the regular attendance for the Sabbath service is about eighty. Ninety per cent of them are Adventists.

\section{Synopsis}

Since the ascension of Jesus, many Christians have been waiting for His return. The subject is "The spirit of waiting" (2 Ti 1:7). Paul wrote to his friend and trainee giving encouragement in connection with his responsibility in the church to which he had been sent. God did not give us a spirit of timidity. Jesus was courageous when He was on this earth. The cleansing of the temple was not an easy task. It takes a courageous man to do it. Paul was another example of a courageous man ( 2 Cor $11: 24-28)$. For the gospel's sake he was willing to suffer. God gave us a spirit of power. The promise is that you shall receive power when the Holy Spirit has come upon you (Acts $1: 8$ ). He gave us a spirit of love. Without love all service is worthless (1 Cor 13). The only way to do away with the spirit of timidity is to have timidity overcome by love. There is no fear in love and perfect love casts out fear ( $1 J_{n}$ 4:8). Paul was imprisoned, yet 
he did not fear, instead he loved the jailer and brought the gospel truth to him. Where did his love come from? (2 Ti 1:12). Paul knew whom he had believed and he was sure that he was able to stand firm until that day. Paul had a spirit of love. God also gives us a spirit of self-control. Christians know how to control self since God has helped us. May God help us to have a spirit of power and love and self-control.

The Use of the Bible in the Sermon

This sermon is an exposition of a text found in $2 \mathrm{Ti} 1: 7$, and the major sermon divisions came from the text: God did not give us a spirit of timidity; He gave us a spirit of power; He gave a spirit of love; and He gave a spirit of self-control. The ideas of the sermon are in agreement with the text. The sermon is divided into its leading phrases and clauses. All the sermon materials are drawn from biblical incidents and ideas except for the last story which is a good illustration for the four points he made. The background of 2 Timothy is briefly discussed but the immediate context is ignored. It is hard to see the correct relation between his subject and the text: his topic was "The spirit of waiting," but the original setting of the main text, 2 Ti $1: 7$, is not talking about the subject. It is an encouragement to Timothy to rekindle the gift of the Spirit. The basic gift had been given to Timothy, but it needed to be developed. Indifference or fear might lead to the gift of the Spirit burning low, so Timothy is reminded that God did not give a spirit of t1midity. Instead, the spirit is one of power--strength to discharge 
the task assigned; of love. and of self-control--essentials in all who would influence others for God. Nevertheless, the thoughts which are developed from the text are biblical truth and illustration. His use of additional texts for supporting the main thought is very good except for the last point on a spirit of self-control. This was not explained or supported by any text. The last story in the conclusion is well chosen for it applies to all four points of the sermon. It is a story from America in regard to a new settler from Europe in the early days. Although some in the congregation do not have any background of American history and customs, the lessons for character building are drawn in such a way that the point of the story was put across satisfactorily. The message has a close relation to Adventist Christians. This is a biblical sermon. 


\section{Sermon Number 15}

Preacher and Setting

See Sermon No. 5 .

\section{Synopsis}

After hearing the story of creation, a boy asked his father, "How big is God, daddy?" We have many gods in the world: they are of different kinds, shapes, and sizes. As we go into the temples of Buddah, we find some idols are small and some are as tall as a hundredfeet. How big is your God? This can be shown by the size of our offering. From the kind of offering we give, we show how big our God is. Jesus placed great importance on the question of offerings. of his twenty-nine parables, sixteen are related to money. This shows that there is a close relationship between our offerings and our faith. An offering is like a measuring rod telling us how big our God is. There are five kinds of people who give: (1) Those who do not give-they have many excuses for not giving. In fact, they are not willing to give. They do not belong to God. If they do, their God is of no importance to them. Jesus said, "Where your treasure is, there will your heart be also" (Mt 6:21). These people will leave the church sooner or 1ater since their heart is not in the church. (2) Those who make token offerings--they think that as long as they give something, it is good enough. They treat God as though He was their child, giving Him some candy money. (3) Those who give according to their mood-when they are moved they give generously but afterward regret what they did. Ananias and Sapphira were a good example of this (Acts 5). 
This kind of giving is not consistent. When they are moved, their God becomes great, otherwise, their god is very small. (4) Those who give systematically--they are willing givers who give according to their means. Paul said that each of us should put something aside in store on the first day of every week (1 Cor 16:2). They are planned givers and they respect their God as the great God who is a great provider. (5) Those who give sacrificially--the love of God controls their daily life and like the poor widow who, by giving two copper coins, gave all that she had (Lk 21:1-4). Their God is greater than their livelihood. Giving to God is a meaningful act. By giving, we starve our selfishness and hasten the work of God. Do you want your God to be great in your life? Let us give generous1y.

The Use of the Bible in the Sermon

This is a topical sermon on a biblical theme. The sermon idea does not have an analytical relation to any one particular verse of Scripture. Yet most of the materials presented are Christian ideas. Instead of allowing the text to be understood contextually and interpreted accordingly, the scriptures are used to support his sermon idea or merely as proof-texts. The use of 1 Cor $16: 2$ is an example of this. It is merely read without explaining its background or context. This means that the emphasis is not on the Scripture itself but rather on the sermon idea. However, the quoted scriptures are not misused and they support the sermon idea well, even though the explanations of the quoted texts are omitted. For 
his second part of the sermon body, no Bible text is quoted; while for the rest of the sermon, one biblical passage for each point is cited. The message is developed loosely with some particular thought in sequence. The last point reaches its climax and it has a searching message. It involves the whole congregation in one of the five categories he mentions. It has a direct relationship to their daily living and their relationship to God. The language is clear and the sermon thought is easily followed. 


\section{Sermon Number 16}

\section{Preacher}

This preacher was converted while serving in the army twenty-three years ago. He was a graduate of a military acadeny. Before he was called to be a worker, he attended Taiwan Missionary College for over a year. He is not a church pastor but is a worker in the mission office. He has been a regular speaker for the Sabbath service.

\section{$\underline{\text { Setting }}$}

The church is located next to the mission office. It has about fifty names on the roll, but the regular attendance is about thirty-five people.

\section{Synopsis}

While the Christian family goes astray from God, He is eagerly waiting for their return so He can forgive and bless them. This is demonstrated in the experience of the family of Elimelech. In the days of the Judges, people did what was right in their own eyes (Jugs 21:25). It was not easy for people to keep their loyalty to God. They went to sojourn in the country of Moab (symbol of the modern world). Later on, Elimelech and his two sons died and Naomi thought of going back to her own country (Ruth 1:1-5). When she went back to God she received abundant blessings. From her story, we can reflect on what kind of Christians we are today. Are we really faithful to God? Do we love our neighbors? How do we treat those backsliders who are planning to come back? (Ruth 1:19). Do we still 
love them? The story also gives us another very important lesson: we should not love the world but stay close with our brethren. We should truly love our brothers (Ruth 2:8,9). Another lesson is found in Ruth $3: 11--$ All the people in the city knew that she was a virtuous woman. Our faith should be lived out in our 1ives. Think more of other people and pay less attention to self.

The Use of the Bible in the Sermon

The sermon is supposed to be a biographical one which deals with the lives of some personalities in the book of Ruth. The main biblical material comes from the book of Ruth except for Jugs 21:25 which describes the historical background of the book of Ruth. The preacher is trying to focus his sermon on the biblical passage but somehow fails to do so. The sermon becomes an ethical discourse and the main emphasis of the sermon is not clear: it starts with Elimelech's unfaithfulness, moves to Naomi, who went back to God, and, finally, focusses on Boaz's kindness toward Ruth. Five passages are read in the sermon but none of them is given careful exegesis. A phrase here and there is cited from a passage and an application of the moral lesson is immediately drawn. For example, by quoting Ruth 2:8,9, he explains that "go not to glean in another field" means "love not the world" and "keep close to my girls" and "follow the gleaners" means that we shouldi not leave the church but love our brethren. The original meaning of the text is not elaborated, but the speaker simply draws moral lessons from several phrases of the text. The same treatment is also seen in Ruth $3 ; 11$. The sermon is actually a personal viewpoint on an ethical subject. The texts of 
the scripture are mistreated. He does not preach the direct contents of the passage. The Bible is not so much the final source for his preaching as it is a crutch on which he relies for support of his personal ethical idea. The sermon mentions God's gracious redemptive act by showing His willingness to accept any sinner who comes back and to bless him. Many moral lessons are drawn from the sermon related to the congregation's situation. 


\section{Sermon Number 17}

Preacher and Setting

See Sermon No. 11.

Synopsis

Everybody is longing for freedom. What we need is not only physical freedom but also freedom for our minds and thoughts. There are two kinds of freedom: true freedom and false freedom. False freedom promises happiness in sinful indulgences. But Jesus said, "Everyone who commits $\sin$ is a slave to $\sin ^{\prime}(\mathrm{Jn}$ 8:34). We cannot belong to God and at the same time belong to Satan (Mt 6:24). Satan induces us by false freedom to be a slave to sin. But Jesus calls us and invites us to be His children so He can restore our true freedom in Him. So often we Christians are led astray by the storm of temptation and lose our direction in life. When we are under sinful influences, there is no power within us which can deliver us from sin. The Bible promises us that Jesus will "proclaim release to the captives and set at 1iberty those who are oppressed" (Is $61: 1-2)$. We are captives of Satan because of our sinful 1ife. Christ came to set us free, so we should not submit again to a yoke of slavery (Gal $5: 1$ ). Sinners are doomed to die, but Jesus came to destroy the works of Satan (1 Cor 15:55). Therefore, if the Son makes you free, you will be free indeed ( $\mathrm{Jn}^{\circ} 8: 36$ ).

The Use of the Bible in the Sermon

The sermon idea is based on the main text $\mathrm{Jn}_{\mathrm{n}} 8: 31-36$. It starts with man's inner need--the search for freedom. Two 
illustrations on the importance of freedom are given in the introduction. The thought for the main discourse is taken from Jn $8: 34$ and Is. 61:1-2. The additional texts, Gal 5:1 and 1 Cor 15:55, are quoted to support the sermon idea. John 8:36 is used to conclude the sermon. His illustrations are all extra-biblical materials and two of them are from Abraham Lincoln's life and speech. While the original and central neanings of the text are employed in the sermon, the context and the exegesis of the main text are missing--the section dealing with the true light and its implication (witnesses against spiritual darkness) is not mentioned. Therefore, the meaning of the text is not quite clear. The text is used to support his idea. The illustrations also are used to explain his idea instead of the text. The illustrations occupied more than half of his sermon. The topic is drawn from $\mathrm{Jn} 8: 32-36$; but the main divisions are not drawn from the passage and his emphasis is placed on the text Is 61:1,2. The work of Christ and the "good news" are proclaimed and stressed. The illustrations made his message easy to understand, but some of them are from the life of an American president. Some members of the congregation might not know anything about him. The method of presentation might be called an inductive method because the key text, Jn $8: 36$; is not mentioned until he comes to the conclusion. The sermon is constructed on the basis of the preacher's personal opinions and what materials he thinks are good. The Bible is used where it seems relevant to him. 
Sermon Number 18

$\underline{\text { Preacher }}$

The preacher is a graduate of South China Union College and has been an Adventist minister for over fifteen years. He has served mainly as a church pastor in a city church and recently accepted a call to be a Union departmental secretary. He is in his mid-forties.

\section{Setting}

The church is located in a big city and it has a membership of five hundred. The regular attendance at the Sabbath service numbers about three hundred.

\section{Synopsis}

We often hear the statement that the Adventist church has the Bible truth, but there is no love existing in the church. The title of this sermon is "The Pharisees and You." Why are you disgusted with the Pharisees? The term "pharisees" means "the separated ones." The chief characteristic of the Pharisees was their strict observance of the law. Later, the name "Pharisee" became synonymous with "hypocrite." The Pharisees emphasized the outward appearance and formality but neglected the inward purity. They were noted for their pride and self-righteousness (Mt $3: 7-10$ ); that is why they had been warned to bear fruit that befits repentance. They purposely displayed their piety before men in order to win the praise of men (Mt $6: 1,2,16)$. They pald lip service to the Lord and taught the precepts of men (Mt 15:1, 7). Their self-righteousness was very obvious from the 
record found in Lk 18:9-14. Nevertheless, there was something good In the lives of these Pharisees which we can learn for our own edification. Jesus mentioned seven woes against the Pharisees (Mt 23) and said, "They preach but do not practice." They were the strictest in their teachings (Acts 26:5). Jesus recognized their merits (Mt 5:20). Nicodemus and Paul were Pharisees. Like Israel of old, the Pharisees had rebelled against God. They held the form of religion but denied the power of it (Amos $4: 4,5 ; 5: 21-23 ; 6: 12 b$ ). Jesus' rebuke to them applies to us today (Mt 12:41). We need to repent! (Joel 2:13). God has told us what is good (Mic 6:8). We should come to church with a humble spirit. Our righteousness must exceed that of the Pharisees. Our worship should be from the heart. We need to have a heart of love and genuine piety (Js 1:21).

The Use of the Bible in the Sermon

This Bible-reading method of exposition of "The Pharisees and You" does not concentrate on one passage of Scripture nor does it develop the topic. It uses many texts to support the pastor's sermon idea. There is no serious attempt to give an exegesis or exposition of the scripture. The preacher merely reads a passage of scripture as a lesson which gives the background for the theme. He followed this approach in most of his texts. There is no main text in the sermon, even though fifteen passages of scripture are quoted. The scriptural passages in the first part of the sermon are trying to describe the defects of the Pharisees, the passages of the second half relate to the practical lessons we should learn. The context and the background of the texts are totaliy ignored since there 
are so many texts in the sermon. The structure of the sermon does not follow any logical sequence, so it is rather hard to follow his sermon Ideas. Even though many biblical materials are quoted to support his points, none of the texts used is fully developed, so actually the sermon could have been preached without the texts. The sermon contains so many texts that there is no room for any explanation, illustration, and application. The elements of the "good news" are not found in the sermon except in Joel 2:13, which is merely read. Nevertheless, there is some bearing in the sermon for the congregation's Christian life and experience. For example, practical Christianity is mentioned by quoting Mic $6: 8$ and Js $1: 21$, and the right kind of spirit for worship and daily living is stressed. 


\section{Sermon Number 19}

\section{Preacher}

This preacher is a teacher in our Taiwan Bible School. He Is a graduate of a government university. He was brought up in an Adventist home and has been in this teaching post for over fifteen years. Being a church elder, he is a regular speaker for the Sabbath worship hour. He is in his mid-fifties and teaches Chinese literature.

\section{Setting}

The sermon was preached at the Taiwan Bible School Church with a group of about one hundred in the congregation. Eighty per cent of them were members of the Seventh-day Adventist church.

\section{Synopsis}

To do a thing properly is difficult, but it is more difficult to be a real man and treat others properly. Jesus' golden rule (Mt $7: 12)$ tells us that the relationship among men is a mutual one. It is not a one-way communication. If you do not want others to treat you badly, you should not treat others badly. If you do not want others to speak evil about you, you should not. speak evil about them. James 3:5-8 tells us that the tongue is a fire. It is an unrighteous world in which we live. We should be careful about our speech lest we lose our eternal life (Ps 15:1-2). Those who will be saved will speak the truth from their hearts. We need to speak more constructively and utter more words of comfort and courage." If you do not want to be treated as a slave, you should not treat others as though they were slaves. The power of love is great. Love can change men's lives. 
Love is giving and not getting. It is more blessed to give than to receive (Acts 20:35). Living with people is not a one-way street (2 Cor 9:6); it is a mutual experience. Let us keep the word of Jesus in our hearts.

\section{The Use of the Bible in the Sermon}

This is an ethical discourse on the topic of Christian conduct. The main concern of the sermon is the proper relationship between Christians and other people, based on the teachings of Jesus which are found in Mt 7:12. Although the text controls the thought of the discourse, it is left unexamined throughout the sermon. He merely gives the background for the ideas of the sermon. The context of the passage is missing from the sermon (i.e., Mt 7:7-11 is an additional exhortation on the subject of prayer and verse 12 seems to be an isolated thought). Nevertheless, we can understand the whole passage in the context of this verse. It appears that the preacher bases Christian ethics on the negative form of this text which was also found in the teaching of Confucious: "Do not do to others what you do not want them to do to you. If, for example, you do not want others to treat you badly, you should not treat others badly." The additional passages of the Scripture are merely quoted and used as sort of a crutch.

It is quite obvious that the sermon uses the Bible rather than letting the Bible use the sermon. The preacher selects biblical materials at random as he would select from any other source (e.g., wise, ancient Chinese sayings) to support his points. The ideas presented are not from the meanings of the Bible text; instead, the 
texts quoted are to support his ideas, his philosophy of life. For example, he says, "If you like to have an afternoon nap without being disturbed, you should not disturb other people during their naps."

The sermon lacks homiletical structure. The speaker makes explanations, uses some illustrations, and occasionally quotes from scripture. Having read the main text, he talks about the proper use of the tongue and the power of love, and he mentions, in passing, some miscellaneous Christian ethics according to his own İdea. Finally, he closes the talk with 2 Cor 9:6.

The sermon is man-centered--it fajis to confront people with God. It only concerns itself with human relationship problems. The sermon overlooks the fact that all relationships should be grounded in a proper relationship with God. The sermon keeps the discussion on the human leve1, it stays apart from the Christian gospel. Nevertheless, his illustration of a parent's attitude toward his son's grade card and an explanation of it are practical and relevant to the congregation's daily life. His use of Chinese ancient sayings gives the congregation a feeling of being at home. 
Sermon Number 20

Preacher and Setting

See Sermon No. 10.

Synopsis

The title of this sermon is "A Precious Privilege" and the text is found in Mk $11: 24$. There are many promises in the Bible for Christians. Our God is merciful and full of great lovingkindness, one who watches over us. He provided a way for us to cone to Him and commune with Him. The way is prayer. Through prayer we can talk to God and tell Him about ourselves and our plans. There are many Christians who do not know how to pray. When we pray we converse with a close Friend. It does not bring God down to us but it brings us up to Him. If we draw near to Him, He will draw near to us (Jas 4:8). The intimacy of our friendship with God can be seen from our prayer life. Also, prayer is like our spiritual breathing. If we do not have a meaningful prayer life, our spiritual life is dead. God is willing to answer our prayers. He cares for us (Ps. 33:13-18; Lk 12:7). Jesus invites us to come to Him with our burdens (Mt 11:28). We have many hardships in 1ife. Peter exhorts us to cast all our anxieties on Hin (1 Pe 5:7). Through prayer, we will be strengthened and our faith increased. Let us maintain a prayerful life so our lives will be happy.

The Use of the Bible in the Sermon

The sermon is dealing with one of the biblical subjects--prayer. Since it is a biblical subject, the main sermon idea comes from the 
Scripture, even though it does not come from the announced main text, Mk 11:24. In the sermon, this main text is used to show the precious privilege of prayer. But this is not the original meaning and intention of the text. This careless use of the text is caused by neglecting the study of the context. In this particular verse, and judging by its context, the thought of the passage is on the subject of "faith" rather than "prayer." By the exercise of faith in God, people can do what appears to be humanly impossible. When man engages in the activity of prayer, his faith in God increases. The texts are not examined in any way, they are simply quoted. Although this is a kind of doctrinal sermon, there are not sufficient scriptures used to give an authoritative foundation for the sermon. Ordinarily, a single text presents only one aspect of the doctrine, so a number of passages are required to give a comprehensive view of the subject. In this sermon six passages are used but none of them is treated in its contextual relationships, nor does the preacher give a comprehensive view of the subject. Five of the texts are dealing with God's care and His willingness to answer our prayers. The sermon is organized according to the preacher's ideas and is not born from the scripture itself. The preacher deals with such thoughts as: (1) what is prayer, (2) the importance of prayer; and (3) God invites and answers our prayers. Thus, the sermon does not explain, illustrate, nor apply the text it quotes.

The gospel is implied in the sermon by using Mt 11:28; Jas 4:8 and $1 \mathrm{Pe} \mathrm{5:7.} \mathrm{The} \mathrm{love} \mathrm{of} \mathrm{God} \mathrm{is} \mathrm{cleariy} \mathrm{demonstrated} \mathrm{in} \mathrm{His}$ willingness to answer our prayers. There is hardly any application In the sermon, though the theme is relevant to every Christian life. 
Sermon Number 21

\section{Preacher}

The preacher is a pastor of a small town church. He graduated from Taiwan Missionary College two years ago. After a year's internship he was assigned to this church as a pastor. He came from a Christian home and is now in his late twenties.

\section{Setting}

The church has about forty members, but the regular attendance is between twenty to twenty-five people.

\section{Synopsis}

"Rejoice in the Lord always" (Php 4:4). Paul is not talking about joy in its ordinary sense here. His emphasis is that genuine joy is in the Lord. What does "in the Lord" mean? He explains in Col 2:6, 7--1ive in Him, be rooted and built up in Him. True joy comes from complete surrender to the Lord. By "in the Lord" we receive the following joys: (1) the joys of forgiveness and being free from the $\sin (\operatorname{Rom} 4: 7,8$ ), no condemnation for those who are in Christ (Rom 8:1); (2) the joy of overcoming fear and death, for Jesus told the disciples, "Let not your heart be troubled. . ." (Jn 14:1-3), for the is the resurrection and the life ( $\mathrm{Jn} 11: 25$ ); and (3) the joy of being free from anxiety (Php 4:6,7), every Christian should

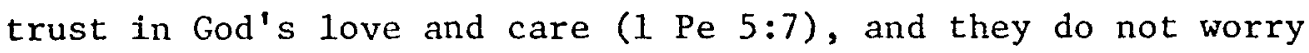
about tomorrow, they daily depend on God for a happy life (Mt $6: 31-33)$ 
The Use of the Bible in the Sermon

The sermon is based on $\mathrm{Php} 4: 4$. It is controlled by the thought of a phrase from the text-rejoice in the Lord. The sermon idea comes from the text and it is developed into a sort of topical sermon, discussing the source of true joy and the various kinds of joy a Christian can have. While the background of the letter to the Philippians is briefly mentioned, the immediate literary context is ignored. The theme here is not really dealing with the subject of joy, rather it deals with the three elements which will help to maintain harmony: "rejoice in the Lord," "showing forbearance to a11" and "remembering the Lord's presence."

The preacher expounds the thought of the text but does not employ close exegesis and careful interpretation. The preacher speculates from the text as to what is genuine joy: the joy of freedom from sin; the joy of overcoming fear and death, and the joy of freedom from anxiety. These are not derived from the text. There was no special effort to examine this text to discover its real meaning. The sermon is packed with many scriptural passages and facts, but an explanation of these texts is not done properly. The additional texts are just read one after another. The text, Rom 4:7, 8, was followed by Rom 5:1 and Rom 8:1 without any exposition. The message contains the essential elements of the gospel all the way--Christ's substitutionary death, glorious resurrection, and abiding presence. There is some relationship between the message and the listeners' Christian life. The preacher's consistent emphasis on trusting the Lord shows that he was trying to relate the message to meet the 
congregation's daily needs, but somehow he fails to do so by just referring to Mt $6: 31-33$ and closing the sermon without applying it to the specific problems of life. 
Sermon Number 22

Preacher

This preacher is a newly ordained minister who has been in the Adventist ministry for over ten years. He has been a pastor for: various rural churches. He attended Taiwan Missionary College for ministerial training. He is in his mid-forties.

\section{Setting}

The church is located in a rural area. The majority of church members come from a Presbyterian background and are mainly farmers. The regular attendance of the Sabbath worship is about eighty people.

\section{Synopsis}

"The Supreme Value of Knowing Christ" (Php 3:8). Paul did not glorify his noble background nor his successful-missionary work; he counted these as loss because of the supreme value of knowing Christ. What are his reasons? (1) To know Christ is to have eternal 1ife (Jn 17:3). Nothing in this world can compare with eternal life, so Paul forsook all to follow Jesus. (2) To know Christ is to have abundant grace and peace $(2 \mathrm{Pe} 1: 2)$. This is an age of anxiety. Education, good position, and wealth cannot comfort us, nor can they give us peace of mind. (3) To know Christ is to be justified (Is 53:11b). (4) To know Christ is to trust Him (Ps 9:10). Money and a good position are not dependable. (5) To know God is to be strong (Dan 11:32b). Nany faithful people of God stood firm for their faith because they knew their God. Jesus has invited us to come to know Him and accept Hin as our personal Savior. 
The Use of the Bible in the Sermon

This topical sermon gets its theme from the Bible text (Php 3:8). Instead of developing it as the Bible text develops it, the preacher treats the topic according to his own reasoning with the support of related Bible texts. The sermon theme comes from the text which controls the thought of the sermon. Five reasons for the supreme value of knowing Christ are explained with a text for each reason. None of them has a direct relationship with Paul's own writings, they come from other books of the Bible. In other words, Paul's own reasons for the supreme value of knowing Christ are not expounded. These five reasons are given by the preacher to convince the congregation as to why we should regard knowing Christ to be of supreme value. The context of the main text is not examined: Paul was talking about his past and present. Nevertheless, the five reasons used are well thought out. The Scriptures used for these reasons are not properly explained but are used to show that these reasons are biblical. For instance, $2 \mathrm{Pe} 1: 2$ is read as the second reason without further explanation of the text--to merely emphasize that men of this age need peace of mind. The meaning of the text is not explored, so the fullness of the text is not covered. The sermon does not leave out the gospel. The "good news" is clearly shown in the sermon--eternal life, justification, grace, faith, and Jesus' invitation are all included. Since this is a significant Christian topic, the message is related to the life of every Christian. Their faith could be strengthened by this sermon. 


\section{Sermon Number 23}

\section{Preacher and Setting}

This sermon was preached by the writer at Taiwan Missionary College prior to his work on this project.

\section{Synopsis}

"Four Aspects of Repentance." (An English translation of this entire sermon is included in this study as Appendix A.)

The Use of the Bible in the Sermon

The sermon is based on Lk $3: 1-5$ with special emphasis on verse 5, dealing with one of the vital biblical subjects--repentance. It is quite obvious that the sermon has a close relationship to the biblical message; sufficient texts and biblical incidents are cited to unfold the sermon thoughts.

Nevertheless, the use of the main text for this particular purpose in the sermon is different from the original intention of the text. John the Baptist is not dealing with the four aspects of repentance in $\mathrm{Lk} 3: 1-5$. This passage is a description by Luke of the work of John the Baptist as a forerunner of the Messiah. John the Baptist did preach about repentance in Lk 3:7-17, but not in verses $1-5$. So it is misleading to use Lk $3: 5$ to say that today's preacher is John the Baptist himself and that his sermon title is "Repentance."

Furthermore, Lk $3: 5$ is quoted from Is $40: 4$. In this whole context, especially in its immediate connection with the comforting prologue, Is $40: 4$ contains a promise and not an explanation nor an 
exhortation to repentance, thus the pastor's use of the text has a different meaning from the main idea of the text in its context. Instead of allowing the text to be understood contextually and interpreted accordingly, it is mistreated.

The preacher makes another serious mistake in this sermon when he yields to a homiletical temptation to allegorize Scripture. In the way he treats the text, he tries to assert a multiple meaning for it. The figure of speech employed in Lk 3:5 represents the preparations to be made in advance of the announced coming of the King. The idea of levelling and smoothing here is that every obstruction shall be so moved as to reveal to the whole world the salvation of God in Jesus Christ. Like the great ones of the earth, the Prince of Peace was to have His immediate approach proclaimed and His way prepared. So John's duty was to bring the people back to obedience to the law and to remove all self-:: confidence, pride in national privileges, hypocrisy, and irreligion so that they should be ready for His coming. While these four aspects of repentance--to turn vanity into contentment; to turn pride into humility; to turn crookedness into honesty; and to turn every kind of grudging and grumbling into prayer--might be seen as devotional thoughts from the text, that is not its original meaning. The preacher does not distinguish the primary meaning of the text from the particular application he makes of it. "Somehow the preacher, wanting the text to be relevant and contemporary, distorts the idea of the text. This may give the congregation the false impression that his sermon expresses the original meaning of 
the text. Here the preacher fails to keep the interpretation of the meaning of the text and the range of application separate.

The message is related to the congregation's dafly experience, but the applications of the message to the congregation lack concreteness. For example, the preacher says: "We must repent by bringing our pride 1ow"; or "We must become 'straight,"" and so on. These are all too abstract and it is hard to grasp what they mean.

The sermon as a whole has good devotional ideas but the text is mistreated. It is used to support the ideas of the sermon without considering its context. This allegorizing of Scripture certainly has no place in biblical preaching. 
Summary

And so a study of twenty-three sermons preached recently by Seventh-day Adventist ministers in Taiwan has been made. The analysis has focused on the relationship of the Bible to the preacher's sermons. In this summary the writer wants to begin with an acknowledgement of the affection and respect which he holds for al1 of these preachers. Since he knows them personally and has worked with them, he can testify to their sincerity, seriousness, and their dedication to their Lord and their aspiration to fulfill the task which the Lord has entrusted to them. He is also aware of the fact that these men have made inestimable contributions in the cause of God in Taiwan. He believes that the analyses of these sermons will be helpful to his own personal growth and competence as a preacher. Also, this analysis has been made for the purpose of determining the actual preaching situation in Taiwan Adventist churches so that his future work of training ministers for these churches may be better suited to meet the needs of the congregations.

No claim is made that these sermons represent only the preachers' best. Each sermon was preached and recorded in the normal course of the work of these ministers. While it is not suggested that this sampling of twenty-two sermons gives a total picture, it is maintained that it does give an overall view of the typical preaching situation in Taiwan. These preachers are representative of the Adventist ministry in Taiwan as a whole. Among them are a mission president, an editor of the publishing house, several Bible teachers from the college and middle school, and ten pastors currently serving in the parish ministry. 
It is obvious that without a clearly defined and commonly agreed upon standard for the proper use of a text in a sermon, there would be a good deal of room for differences of opinion as to the correct or incorrect use that has been made of the text. And undoubtedly the preachers themselves as well as the people who listened to these sermons could disagree in many instances with the comments which the writer has made.

Although all of these men have used the Scriptures to some extent, as would be expected, there are some areas of weakness in the handing of the Scripture.

One major conclusion from the study of these sermons is that the topical sermon is the prominent type among Seventh-day Adventist preachers in Taiwan. Nineteen out of the twenty-two sermons are topical in form and content. The reason for this could be that the topical sermon grants greater freedom to the preacher; he can preach without having to confine himself within a single passage and thus preparation is made relatively easy, since this approach requires the least amount of study of historical background and biblical research. ${ }^{1}$ Another reason is that in these sermons the emphasis is placed on the biblical doctrines characteristic of Seventh-day Adventism, and doctrinal sermons are usually topical in form.

The topics of these sermons are largely related to Christian living and ethics. Among these are "Consider Your Ways," "The True

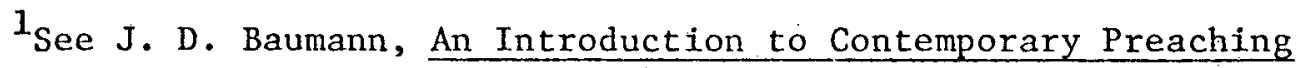
(Grand Rapids: Baker Book House, 1972), p. 101. 
Temperance," "Jesus Our Example," "The Secret of the Victorious Life," "Joy in the Lord," and, "The Right Way to Treat Others." This emphasis on ethics is probably caused by the fact that Chinese tradition places great emphasis on ethical and moral principles in human relationships. Since for centuries the Chinese have stressed the supreme importance of religious faith and moral principles and since they find the same elements in Christian teaching, they find it relatively easy to accept Christianity. For this reason, Chinese preachers tend to utilize their national culture in preaching Christianity. On the other hand, they should be aware that this approach tends to distort Christianity by making it into a system of ethics, morals, and humanism. Eventually this leads to the wrong emphasis and may well repeat the mistake that the other religious faiths have made in conceiving of religion as a system of salvation by works.

Another common characteristic among these sermons is the level of language used. As has already been mentioned in the analysis of each sermon, the language used is simple and can be easily understood. These preachers communicate the message in the language of the common people, employing a simple vocabulary which actually represents the speaker's own level of language. Because of this, the intellectuals and the sophisticated in the society are generally not attracted by Adventist preaching. This is one of the drawbacks Adventists have in Taiwan; that is, there has not been much contact with the more educated class of people because of the ministers' lack of higher education. 
Within the framework of the criteria suggested at the beginning of this chapter the following has been found:

1. Although the majority of sermons begin with the reading of a text--usually a very brief one--the text is frequently not the real basis or source of the sermon ideas presented. The text serves rather as a point of departure, or, in some cases, a unifying theme or motto for the topic. For example, in sermon 5, "Consider Your Ways," Hag 1:5 is cited as a sermon text, but it is expounded and used as a spring board for the whole sermon, which consists of the elaboration of five ideas concerning Christian conduct. Sermon 22, "The Supreme Value of Knowing Christ," uses Phil. 3:8 as its text, and this is read at the beginning without any attention given to the content and meaning of the text. The text is used as a unifying motto, and the preacher develops his five reasons as to why we should know Christ.

In true biblical preaching, the preacher's first task is an exegetical one. He is to expound or to interpret the meaning of the text before him. According to J. A. Broadus, the explanation of the Scripture is "among the primary functions of the preacher."1 But some of these sermons use the Bible merely to justify and to give support to the speaker's own ideas, and they fail to give serious consideration to the texts and do not set forward a valid interpretation. This is one of the major weaknesses of these sermons.

${ }^{1} \mathrm{~J}$. A. Broadus, On the Preparation and Delivery of Sermons (Nashville: Broadman Press, 1944), p. 157. 
2. Another major weakness is that when the text is dealt with, it is often related inadequately to its context. Although this is somewhat similar to the first weakness mentioned above, there is a difference between the two: the first issue has to do with whether the text serves as the basis or source of the sermon's ideas; and the second is concerned with the natter of proper exegesis of the text. In proper exegesis, the text must be seen both in its literary and historical settings. l'ost of these sermons ignore this principle. This leads some of them eventually to the serious problem of a misapplication of the Scripture because their context has been neglected. An illustration of this is found in sermon 9, "Beyond our Fondest Hopes." Although the sermon has a good biblical message, the text, 1 Cor 2:9, is misused. The whole sermon is developed on a superficial meaning of the text. If its context is taken into consideration, one finds that the text has an entirely different intention and meaning from that which the preacher presents. The text is misapplied because the original contextual meaning is overlooked or ignored. Thus, the relationship of a passage to verses, paragraphs, and chapters in its proximity deserves particular attention by the preacher, because the context of the passage sheds much light on its intended usage and meaning.

3. A further weakness in these sermons is that there is a relatively low degree of harmony or correlation between the content and purpose of the sermon and the texts used. The content of the sermons preached may have only a slight relationship to the texts from which they make a start. An example of this can be found in sermon 
10, "Gospel Invitation." The emphasis of the text Lk 14:16-24

is on people rejecting the gospel invitation, but the sermon stresses

Christian witness and service. Thus, it misses the original intention of the text. The content and purpose of the sermon are not correlated even to the obvious meaning of the text. This weakness can be corrected if the preacher really searches for the original meaning of the text and allows the text to speak for itself instead of trying to put his own ideas into the text.

4. Many sermons, as they are presented, do not include the Christian gospel either explicitly or implicitly. Although some topics or texts contain great truths, the gospel is not presented as persuasively as it should be. Since the gospel is the power of God unto salvation to every one who has faith (Rom $1: 16$ ), it should be presented in a convincing way calling for a right decision. In some sermons, the great gospel texts are merely read or referred to without further elaboration or without applying them practically to the individual 1isteners. They are presented as a kind of dull message not having much relevance to the needs of our modern age. Sermon 7 , "The Love of God" ( $\ln 3: 16$ ), should demonstrate the power of the gospel with conviction, but it comes to the listener only as a past event and it has no appeal to the 1istener. In sermon 10 , "The Gospel Invitation," the gospel is referred to, but what Jesus could really do for those who are willing to accept the gospel is not emphasized. The preacher should remember that the Word of God is always the "good news" from whatever angle it may be presented to His people. Without the gospel the messenger has no message, and he speaks without any authority. 
5. It is noted that while some preachers are trying to adapt their sermon materials to their audience, as in sermons $3,4,6$, and 14, others do not pay special attention to this vital element of effective biblical preaching--meeting the needs of contemporary life. For example, in sermon 8, "The Fear of the Lord," the message is not explicit and the text is not explained in full. Instead of relating the message to his audience in concrete and meaningful ways, the preacher concludes the sermon with a general exhortation. The sermon is not directed to meet the needs of present day life. In biblical preaching, the living gospel should always be preached in such a way that it is related to a practical situation--similar to the way in which Jesus took note of the people, met them where they were, and took account of their needs.

If the writer has correctly interpreted these twenty-two sermons, his analysis of them would lead to the belief that there is still a great need for sound biblical preaching among Adventist preachers in Tajwan. Although the Bible is used in these sermons, some preachers give the Bible only a secondary position while allowing his determinative power and his logic to occupy the highest place. God has a special concern for this present generation and he has revealed His will to all through His Word. He commands His followers to preach His Word. The mere believing of these facts is not enough. Only when the word of God is handled in a right way will the words of Heb 4:12 come true: "For the word of God is living and active, sharper than any two edged sword, piercing to the division of soul and spirit, of joints and marrow, and discerning the thoughts and intentions of the heart." 


\section{CHAPTER IV}

\section{SYLLABUS}

\section{Introduction}

The major objectives of this project from the writer's perspective were to develop insight and understanding with respect to biblical preaching in general and Seventh-day Adventist preaching in Taiwan specifically and to enhance his teaching skills in the area of biblical preaching. The fulfillment of the latter objective begins by giving the introduction to a syllabus on preaching. The particular portion of the syllabus which relates to the specific issue of biblical preaching appears in Appendix $C$. The intent is to employ this syllabus in teaching a homiletics class at Taiwan Adventist College. Although the outlines which appear in Appendix $\mathrm{C}$ are in English, the class will, of course, be taught in Chinese.

Taiwan Adventist College, which was established in 1952, is sttuated at Hsin-Tien, Taipei, Taiwan. Last year the campus was moved to a new rural location in the central area of Taiwan. This college belongs to the Seventh-day Adventist denomination. It provides a Christian education for the youth and aims to train future ministers, teachers, and office workers for the denomination. Students are admitted to the religion curriculum after graduating from senior middle school. In the lower division 
classwork the students complete such basic courses as Bible Survey, Life and Teachings of Jesus, and Bible Doctrines. During their junior year they study Major and Minor Prophets, Personal Evangelism, Comparative Religion, and some general subjects. The Honiletics class is open to either junior or senior students. Homiletics is a three-quarter course with two hours of credit each quarter. The class meets for two fifty-minute periods per week.

The purpose of this beginning course in Homiletics is to help the student establish a firm foundation of knowledge in the field of preaching. The course stresses understanding the nature and purpose of preaching, the theory of preaching from the Bible, and the preparation of sermons.

The section headings for the syllabus prepared for the Homiletics course are as follows:

1. Preaching, Its Nature and Function

2. History of Preaching

3. Preacher, Message, and People

4. Christ, the Master Preacher

* 5. The Bible, the Preacher's Source Book

* 6. Choosing the Text

* 7. Interpretation of the Text

* 8. Christ, the Central Theme in Preaching

9. Formulating the Sermon Structure

*Outline materials for these sections relate particularly to this project and appear in Appendix C. 
10. Sermon Types and Variety in Biblical Preaching

11. Sermon Outlines

* 1.2. Biblical Preaching and Cultural Context

13. The Role of the Holy Spirit in Preaching

14. The Place of Preaching in Worship. 
CHAPTER V

\section{OVERALL EVALUATION AND CONCLUSIONS}

This brief chapter will contain an overall summary of the study made for this project and a statement of the personal stimulation and growth experienced because of this study.

According to the writer's knowledge this is the first extensive investigation made of the preaching situation of the Seventhday Adventist Church in Taiwan. Therefore he believes in the significance of this project and that it will facilitate the future development of preaching skills in Taiwan where the writer will be teaching ministerial students.

\section{Summary}

In the first chapter, "A View of the Nature and Purpose of Preaching," the writer endeavored to clarify in his own mind, and those of his readers, the solemnity of the task of authentic biblical preaching. He sees preaching as a dynamic, Christ-event wherein the living, redeeming God reveals His act of redemption in a living encounter with men through the ambassador-preacher who first listens to and then proclaims the gospel and interprets the given word of God in contemporary language to the hearts of the individual hearers. 
On the basis of this understanding, it would seem clear that the preacher of the gospel must recognize the unique place of the Bible In real preaching. From the nature and purpose of the Bible, from Jesus' exanple while He was on the earth, and from the perspective of human need through the ages, the writer believes that true preaching should be biblical in its thought and content. In other words, preaching should be true to the biblical ideas. To summarize in the thought of John Knox, biblical preaching concerns itself with the character of God. It is also concerned with the nature of man. It points out the way of escape from man's sinful condition through declaring God's deed in Christ, bringing reconciliation with God. It is also fundamentally concerned about Christ. ${ }^{1}$

With this emphasis on the place of the Bible in preaching, which is dealt with in chapter II, one concludes that biblical preaching means that the chosen ambassador of God, depending on the direction and guidance of the Holy Spirit, goes forth in an effective and persuasive manner and forms the heart of his message on scriptural texts and relates it to contemporary hearers, helping them to establish a persona1, redemptive relationship with God. So the preacher should preach with insights he has gained from the Bible rather than using the Bible to support his own ideas or as a source of illustrations. He should not take a text or select a biblical incident or story to serve as a point of departure; he should take a passage and with all seriousness search out its authentic meaning for the contemporary audience.

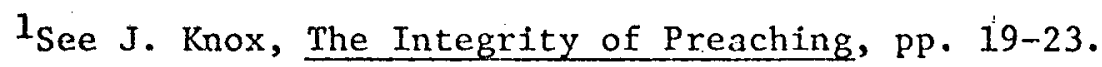


The analysis of these twenty-three currently recorded sermons from Taiwan was based on the convictions outlined above. Seventhday Adventist preaching in Taiwan has a comparatively short history. Obviously, it would be premature to make any final conclusions about It, yet it has been a challenging and interesting study to examine these sermons.

The analysis of the sermons in chapter III led to the conclusion that in general they are not as strong as they ought to be because of the way in which the Bible was used and interpreted. Some of these sermons do not clearly reveal Christ and His redeeming grace. Hearing these taped sermons several times, and having a personal acquaintance with the preachers and their churches, the writer feels that many of the preachers examined appear to have falled to interest or to challenge their hearers. Their preaching seems to give little help to the problems of daily life and is not people-oriented.

Some ideas for the future teaching of Homiletics will be based on the findings from these sermon analyses. One section of a syllabus on preaching has been prepared in chapter IV. It seeks to show the best way to meet the need of the preaching situation in the Taiwan Adventist Church. In these five lessons, the writer emphasizes that preaching should be biblically oriented. This writer believes the Bible is the word of God and that it has messages and meanings for the entirety of man's existence. Therefore, authentic preaching has the Bible as its best source for sermon ideas. The preacher as a servant of the Word must take time to listen to the Word, and it is his primary task to interpret and to examine the Word in such a way 
that the text of the Bible has a real bearing on practical living situations today. As an ambassador of God, he must pray that in the context of his faithful proclamation the presence of Christ may be discovered and a relationship with Christ established. The syllabus also stresses that both the Bible and Jesus Christ must have meaning in the present situation and that preaching should not neglect the interests and needs of the people. In fact, when Jesus revealed himself the third time to His disciples by the Sea of Tiberias, He said to Peter, "Feed my sheep" ( $\mathrm{Jn}_{\mathrm{n}} 21: 15-17$ ). The writer believes that by the grace of God an emphasis on biblical preaching will nurture the believers spiritually and will strengthen their faith in the Lord so that they will be ready for the soon coming of Christ.

\section{Conclusions}

From these studies the following conclusions may be drawn:

1. It is felt that a valid theology of preaching is a must for every preacher. Only when a preacher has a correct understanding of the nature of preaching can he perform this task with renewed dedication and zeal. Taiwan urgently needs such preachers.

2. Effective preaching demands a particular way of listening to Scripture. The preacher does not concern himself merely with what the Scripture says on the surface, but he also focuses on what the Scripture means. In a word, sound biblical preaching demands a correct understanding of the Bible. The hermeneutical aptness of the preacher is a must. He needs to explain carefully and interpret correctly the ways of God's dealing with men. 
3. The ambassador-preacher must know the Bible as the living word of the living God. It is not just a compilation of ancient literature. It is the word that abides in the heart and changes the lives of men. The Bible is the only book of study that is indispensable for a faithful preacher.

4. Biblical preaching is identifiable in its thrust, addressed as it is to particular needs and concerns. As Buttrick says, "Preaching is specific: its language is particular, and it is addressed to a particular congregation." 1 True preaching is never "in general." When the preacher can bring text and daily experience together, when he is able to relate scripture meaningfully to his particular hearers and touch their lives, his parishioners will be hearing words from the Lord and will respond.

5. Biblical preaching is done in the presence of God and Christ. True preaching occurs when the words of a preacher are used by God to disclose His purposes and to voice His claims. Paul seems to suggest in Rom 10:8ff. that preaching is done in honor of the real presence of Christ.

The great need for sound biblical preaching in Taiwan has been shown through this study. The people of Taiwan both within and outside the church are not acquainted with the word of God and they have not been nurtured by it. A few years ago the writer had the privilege of visiting some church members in Taiwan. Several of them expressed their feeling that the Sabbath worship service had

$1_{G}$. A. Buttrick, Sermons Preached in a University Church (Nashville: Abingdon Press, 1959, p. 7). 
become a kind of social gathering. The word of the Lord was not heard and worship became meaningless. Statistics show that the regular attendance at the Sabbath worship service in Taiwan is rather low when compared with the church membership figures. Of course, there are many contributing factors. In part, it may be due to the recent economic progress seen in Taiwan. Many people have attained an affluent standard of living, and they tend to place their faith in material things and find it increasingly difficult to take time for church attendance. But this writer strongly believes that this decreased church aitendance definitely has some relationship to inadequate preaching. His feeling is that many church members regard the sermon as harmless but boring. The crisis of a biblically starved church is with us in Taiwan today. If one expects to see a better church and a healthier spiritual growth in Taiwan, the leaders of the church should be aware of the fact that fiathful biblical preaching is a difficult task and has a high price tag. The cost is in terms of adequate time for deeper Bible study and sermon preparation.

\section{A Personal Stimulation and Growth Experience}

This study has given the writer some significant insights for his preaching ministry and his teaching of Homiletics in Taiwan.

Through the course of this project, the writer was able to acquire further understanding of what preaching really is. In the Doctor of Ministry program, the class in "Word and Worship," taught by Professor Louis Venden, challenged the students to have a valid theology of preaching, a subject of which the writer had only a 
vague concept and had never thought of forming for himself. In the course of this study, under the direction and guidance of his project supervisor, the writer has tried to develop a worthier view of the nature and purpose of preaching.

The study has also led the writer to question, "To what extent are his own sermons and other sermons preached in Taiwan distinctively biblical?" He has come to a better understanding of what biblical preaching is, something he had not had an opportunity to develop before. This study has led him to the conviction that if preaching cannot be honestly related to the Bible, it cannot be called Christian preaching. This has compelled him to see his own weakness in preaching. In the past, he has used the Bible either as a point of departure or in a "proof text" way in his sermons and has preached simply with an idea that a sermon should be supported by the Bible. This study has further helped him to have a desire for a creative approach which treats the Bible as the genuine source of the contents of preaching. He believes this project has aided him toward both a greater and a more intelligent use of the Bible in his own preaching. Furthermore, through the project, the writer has gained added confidence for designing a syllabus for his homiletics teaching in Taiwan. With the help of his professors and wide reading in the works of many homileticans, a portion of a class syllabus has been prepared. The writer expects this syllabus will need improvement in the years to come but feels that this is the first step toward more effective teaching. 
In his preparation of the sermon which appears as Appendix B, the writer has made an effort to apply his learning to the actual preparation of biblical sermons. While this is not necessarily intended as a model of homiletical excellence to be copied, it is a sermon which demonstrates the deep concern for biblical preaching which forms the basis of this project.

Besides these personal experiences and the stimulation toward personal growth in competence as a preacher, the writer's burden is that by his example and teaching the students of Taiwan Adventist College may develop and strengthen in preaching competence, that they will take the Bible seriously in their preaching, and that they will see themselves as servants of the Word.

It is recognized that this study has definite limitations. Some areas touched on here could be studied further through a carefully conducted interview with each Seventh-day Adventist minister in Taiwan in regard to his sermons. It could also be helpful to examine some aspects further after a few years of teaching Homiletics at Taiwan Adventist College.

Because the 1ong-range results of this study in terms of an improved ministry in Taiwan cannot be tested and evaluated within a short period of time, the study lacks empirical support for its conclusions. In addition, there are other areas of emphasis in preaching that have hardly been touched here: matters such as sermon form, organization, style, and delivery.

Along with these limitations, the writer also believes that in some other areas continued growth and improvement could be 
made. For example, experimental studies and programs could be designed and tested in an actual church situation so that one could observe exactly how a congregation would react to this kind of biblical preaching. Another study which could be of great profit would be the examination of a successful preacher in Taiwan (either. Seventh-day Adventist or some other Protestant preacher) to determine how his preaching is related to the Bible and what attractions there are to his preaching. Another very fruitful study could be done in the area of sound biblical interpretation and j.ts relationship to preaching.

Finally, a personal note as I bring this project to a close. I do sincerely pray that by the grace of God, I and my students and fellow workers in Taiwan will learn, painstakingly and thoroughly, how to become truthful servants of the Word so that improvement in the ministry of preaching in Taiwan will be seen and, as a result, many souls may be won to God's kingdom through that faithful ministry. 
A P P E N D X 


\section{APPENDIX A}

This sermon is number 23 in chapter III of this project report, "An Analytical Study of Adventist Preaching in Taiwan." It was preached by the author prior to his doctoral study and is offered here in its entirety in an English translation. An evaluation of the use of the Bible in this sermon appears in the body of the report on pages 124-126. 


\section{Four Aspects of Repentance}

We might say that today's preacher is John the Baptist himself and that his sermon title is "Repentance." Most believers think that the subject of repentance is exclusively for unbelievers; but if our study on this topic has any depth, we will discover that Christians, too, have a great need for it.

of the seven churches in Asia Minor mentioned in the second and the third chapters of Revelation, Jesus told five of them to repent. Which two were not counseled to repent? The first one was the church at Smyrna. Now, Smyrna means to suffer. A Christian who suffers can understand what it means to repent. Only those who repent can walk closely with God, and only those who have a close walk with God can be led by Him and be delivered from their sufferings. This is why God did not tell the church at Smyrna to repent--it had already done so.

The second was the church at Philadelphia, which means brotherly love. The church which manifested brotherly love must have been a repentant church, for without repentance there will be no love for God or men. The very fact that five churches were told to repent shows the great significance of repentance for God's people, and its important place in our preaching.

A casual glance at the first two verses of the third chapter of the Gospel of Luke may not reveal anything very 
meaningful. One might think that it only shows how keen the historian-physician was on the details and surrounding circumstances in which John the Baptist preached his sermon. Luke mentions Tiberius Caesar. Caesar means Roman emperor; Tiberius was the second Roman emperor. As the historical setting for this sermon, Luke refers to five political leaders and two religious leaders--priests. But the listing of these figures was not merely to provide a historical background. Rather, it conveyed profound spiritual significance. There were Caesar, governor, tetrarchs, and high priests, but God did not send His word to any of them. Instead, He sent it to a young man, a common man, John. What is more, God's word was not sent to the emperor who lived in his palace, nor was it revealed to the high priest who worked in the temple; it was conveyed to John who was in the wilderness. The wilderness here is a desert. One cannot expect to find anything much on which to place one's trust in the desert. One can only trust in God, and this trust was what John had and what Tiberius, Pilate, Herod, and Caiaphas did not have. It was because of this trust John separated himself for God, and he received the word of God. (This is one reason why we have chosen this location for our Taiwan Training College, away from everything, extremely secluded in a valley, and with poor transportation. We can not see too far horizontally, we are forced, like John of old, to look up to God to receive God's word.) Those who rely on worldly honor, power, position, and money would not trust God, would not seek God's word. His word is sent to those who are weak, who are poor in spirit. 
When the word of God came to John he could not hold it back, he had to preach this word, and he preached a baptism of repentance. We all know that John was born about six months before Jesus so he could prepare the way for Him. When we see our Chinese head of government travel to a certain place, we notice that there are always military policemen going before him, preparing the way for him. John's work was to prepare the way for Jesus, and in order to prepare Jesus' way, he preached on repentance; and before Jesus can come into our hearts, we must prepare the way by having a repentant heart.

To repent means to turn direction. For example, when you tape your talk and discover that you have made a mistake, you must turn back the tape in order to correct that mistake: Simultaneously, you erase the mistake as you record anew. Based on this modern invention, we can see how wonderful is God's way. of making things right in our lives. We say or do something wrong, and in order to correct the situation we first of all must turn--turn back and turn away from the wrong direction. When we have turned, then God, by means of Jesus' precious blood, can cover our mistake and forgive our sins. This experience of repentance gives each believer a new start.

When John came to preach he quoted from Isaiah the prophet saying: "The voice of one crying in the wilderness; Prepare the way of the Lord, make His paths straight."

Then in verse five, he outlined the meaning of true repentance. First, "Every valley shall be filled.". To build a highway, 
the workmen a1ways fill up the hollow spots first. There are many swamps, many hollow places in our human hearts that are almost unlimited in their capacity to eat up our energy. Only God's grace and mercy can fill--can satisfy--the emptiness, the vacuum in our souls.

King Solomon in opening Ecclesiastes repeated the theme "vanity" quite a few times. Major dictionaries give the impression that "vanity" means to be destitute of reality. This is in harmony with the rendition of the Living Bible which translates: "Nothing is worthwhile, everything is futile" (Ec 1:2). Unlike his father Davị.d who suffered much, Solomon grew up in prosperity. God gave him much peace; in fact, his name means the "Lord of peace." He inherited a great kingdom, he had power, honor, and all kinds of blessings. He was chosen to build God's temple. God gave him wisdom surpassing any mortal man. He was an expert in natural sciences. The world admired him. But he sịnned in later life, and as an old man, he wrote Ecclesiastes to express the emptiness of a godless life. He said, "Vanity of vanities, all is vanity . . . and there is nothing new under the sun." After tasting every possible worldly pleasure he concluded his whole experience with the word "vanity," saying to us that all the pleasures of the world cannot fill life's greatest need.

Friends, even though we may not have what Solomon had, like him we can possess the Lord who can fill up every vacuum and emptiness in our hearts. Paul said he counted all things but dung that he may win Christ. If we have Christ, what else do we 
need? A person who has Christ has all. Jesus said that even Solomon in all his glory was not arrayed like the lilies in the field. Anything God-made is better than man-made. Solomon must have had the very best, but even his very best was not good when compared with what God can give.

Young people, if you want the world, if you desire pleasure in sin, it will never fill your need. If, on the other hand, you choose Christ, the worldly things will soon lose their appeal, because every valley in your heart will be filled.

We who possess Christ may at times feel that there are still empty spots in our lives. Why? It is because we have not received the more abundant life which Jesus has promised to give. If we fail to receive the peace--the rest--He wants to give to us, we must repent so He can fill up all the valleys in our hearts. We should pray to Him, saying, "Lord, I am a sinner, I desire things that are outside of You. Help me to repent."

Secondly, "every mountain and hill shall be brought low." Mountains and hills are protruding formations; they represent our pride, our arrogance, our self-righteousness, our unworthy att1tudes toward others, our ungodliness. We have many of these mountains and hills in our hearts, and they must be bulldozed, cut, brought low. Often even though we know that we are proud, we refuse to repent of it. Even after listening to the still, small voice of the Holy Spirit, we simply quench Him, grieve Him, and become care1ess. 
Those who are truly learned are normally very humble in their attitudes. But those who do not know very much are the ones who act as though they know everything. This is equally true in our spiritual lives. Spiritually speaking, there are several types of pride (haughtiness):

1. There is the superiority complex. Naaman, commander of the army of the king of Syria, was a leper. He was induced to go to see Elisha who told him to wash in the River Jordan seven times to be cured. Naaman's reaction was one of haughtiness, for he said that the rivers of Damascus were better than all the waters in Israel. This was pride. He felt that what he had was better than what God was about to give to him.

We are not much better or different. The Chinese always think that their moral standards, their culture, their philosophies are far superior than anybody else's.

The Samaritan woman was quite sure of the fact that Jacob's well was the best well to have, not knowing the living well Jesus had to offer would be so much better.

2. The "I must be right" attitude, which is a variety of pride. Peter thought he was dead right in his effort to persuade Jesus not to go to Jerusalem so that He would not be crucified. He was forceful in his effort to stop Jesus from even making a start.

Later on, knowing that Peter would not be willing to communicate with Cornelius because he would insist that he was right in not having anything to do with any Gentile, God gave him 
a very unusual vision. He saw a great sheet coming down from heaven containing all kinds of animals and reptiles and birds. And there came a voice to him, "Rise, Peter; kill and eat." Peter's unthinking response was, "No, Lord." He always felt that he was right, he could not accept new guidance--new light. This is pride. We tend to hang on to a set of immovable doctrines to the neglect of the leading and prodding of the Holy Spirit. Yes, we must repent by bringing our pride low.

3. "And the crooked shall be made straight." This is the next area for the work of repentance. There is a promise in the 84th Psalm which says: "No good thing does the Lord withhold from those who walk uprightly." If we walk uprightiy, we will receive all the good things from God. If good things are not found in our lives, we should consider whether or not we are indeed walking in an upright manner. We must rid ourselves of crookedness, cunning, string-pulling, scheming, and the like. We must become "straight."

The life of King Saul is a good illustration. I Samuel chapter 9 tells us that Saul was not only tall and handsome, the people all adored him. He was a young man with a bright future. Eventua1ly he became the king of the nation. But how sad was his ending as the very first king of Israel. It was the crookedness in his heart that caused him to disobey God. When the Lord instructed him to utterly destroy the whole of Amalek, Saul allowed that crookedness to have its way and he kept alive Agag, Amalek's king, and the best of the oxen and sheep. When Samuel rebuked him for 
disobeying God, Saul argued that he had indeed obeyed, that he had taken the best things for the purpose of making offerings to God. Crookedness of our hearts will make what God hates appear to us to be the best. It is only by the indwelling Christ that the crooked ways in our lives will be eliminated.

4. "And the rough ways shall be made smooth." In Chinese literature we have a saying that goes like this: "unlevelness causes grumbling." Indeed, a motor car will grumble on a rough road. In church life, we certainly see people grumble over "rough ways" in the church. Of course, theoretically, there should be nothing rough in church life. But since we are human, this is not. reality as yet. To grumble--to complain--is not Christian. When we come face to face with rough ways, our best approach is to pray over them. If you feel that you have been wronged, listen to this: "Beloved, never avenge yourselves, but leave it to the wrath of God; for it is written, 'Vengeance is mine, I will repay'.". (Rom. 12:19) So pray and do not grumble when things get rough.

Two women in the Bible had been wronged. The first was Samuel's mother Hannah, the childless wife of Elkanah. She was provoked by Elkanah's other wife who had children. It was extremely upsetting for Hannah who had to walk on these rough ways. But instead of grumbling, she prayed; what is more, she took the trouble to go to God's temple to pray. Eli observed her mouth and thought that she was drunk. But God heard her prayer and gave her a son, Samue1, a name which means "to pray." 
Another woman who was wronged was Rache1. But her reaction was very different from that of Hannah. Jacob had two wives also. His first wife, Leah, though not good-looking had children. The second wife, Rachel, was pretty but childless. It was rough for Rachel that she could not have even one child. So she envied her sister and said to Jacob, "Give me children, or I shall die!"

In response, Jacob said, "Am I in the place of God, who has withheld from you the fruit of the womb?" Besides grumbling, Rachel manipulated and gave her maid Bilhah to her husband which resulted in the birth of Dan, a name meaning "to revenge."

Compare the response of these two women: the one who prayed over rough ways bore a son whose name meant "to pray" and whose life was dedicated to the service of God; the other who grumbled and manipulated over rough ways also through her maid bore a son, but his name meant "to revenge," and his descendants were the source of trouble to the nation of Israel. One serves as our example; the other, our warning to help us straighten out our Christian pathways.

The four aspects of repentance, therefore are: (1) to turn vanity into contentment, (2) to turn pride into humility, (3) to turn crookedness into honesty, and (4) to turn every kind of grudging and grumbling into prayer. These are important for they are the first steps in the Christian's pathway, but they are not ends in themselves. If John the Baptist had stopped right there, these steps would not be very much a help to us. Why? Verses 15-17 of Luke 3 provide the answer. 
You see, John was a mere man, and as such he could only ask people to repent; but only the Lord Jesus can give us truly repentent hearts. It is because of His incarnation, His crucifixion, and the power of His resurrection that we are made able to repent. John can challenge us to repent but he can not enable us to repent; only Christ can do this for us.

Verse 15 tells us that the people in Jesus' time were expecting Jesus and thought John was Jesus. But John told them straight he was not and that he was not even worthy to untie Jesus' sandals. He told them that his baptism was for repentance; but the baptism which Jesus would administer would be that of the Holy Spirit and of fire.

It will not be my sermon which brings you true repentance and salvation. It is the indwelling Spirit who does that. John concluded with what he thought to be the most urgent message: "His winnowing fork is in $\mathrm{His}$ hand, to clear his threshing floor, and to gather the wheat into his granary, but the chaff he will burn with unquenchable fire."

So, just to listen to this sermon is not sufficient, you must receive life from the Lord of life. He will give you repentance which will enable you to obey Him and to be truly repentant. A truly repentant Christian realizes that he is totally dependent on the Lord, and this realization resembles the feelings of a person in the wilderness. How helpless! It is then that the word of the Lord can come to you as it came to John the Baptist of old. God's word brings us repentance, and in turn, we will lead others into repentance. Thus we can prepare the way of the Lord's Advent. 
APPENDIX B

This sermon, "God's Amazing Grace" is offered as a sample of the writer's current effort to apply the results of his study to the actual. preparation of biblical sermons. While it is not necessarily intended as a model sermon, it is an effort to demonstrate the writer's concern for biblical preaching which has resulted from this project. The English translation is provided through the kindness of Edward Han-Tsung Ho. 


\section{God's Amazing Grace}

Text: I Cor 15:9-11

While discussing Christ's resurrection and the sure hope of resurrection for all who believe in Him, Paul, in this chapter, expressed some heart-felt feelings of amazement, humility, and gratitude. There are many prophecies in the 0ld Testament concerning Christ's death, burial, and resurrection. There are, too, many witnesses to the fulfillment of these prophecies. But in these few verses, Paul was amazed that he was so honored as to be one of these witnesses. He realized from personal experience that Jesus was not only the resurrected Savior but that He was a gracious Lord.

What distinguishes Christianity above all other religions is that, apart from the fact that it has a profound system of theology, it has the most wonderful and gracious God. His grace is the whole content of Christianity, the very substance of the teachings of Paul and the other apostles. We are forgiven for our sins because of this grace; we receive new lives through this grace; and we live, move, and have our being by this grace. This knowledge is basic to all Christians.

Some Christians give up their faith in the face of poverty, trials, and war tragedies. They do so because they fail to understand the nature of God's grace. They trust self more than they 
trust God. Paul realized that a successful, victorious Christian IIfe has its source in God's grace.

Throughout Paul's writings are many statements about God's abundant grace. But nowhere does he express more beautifully the power and effectiveness of God's grace in his life than is found in our text where he writes about: (1) his apostleship, (2) his becoming what he was, and (c) his more abundant 1abor. These te11 us that God's grace completely filled Paul's 1ife, that it was the source of his strength, and that it was the motivating force of his service.

I. Paul the sinner became Paul the apostle:

"But by the grace of God I am what I am." One dictionary defines "grace" as that which gives joy or pleasure. It conveys the idea of beauty, gracefulness, loveliness--something that delights the beholder. "Grace" also means undeserved kindness, favor, or good will. But the distinctive meaning of the term "grace" in the New Testament, and especially in Paul's writings, is the abundant saving love of God toward sinners as revealed in Jesus Christ.

Paul appreciated the loving nature of God's grace in a rather unique way. He recalled that once being the chief of sinners, deserving death, he had no right to be God's child. But by divine grace, Saul the sinner became Paul the apostle. From being a persecutor against the early Christians, he became the greatest apostle in Christ's cause. (See I Ti $1: 13-15$. ) No wonder he exclaimed, "But by the grace of God I am what I am." In other words, Paul was saying that the degree of his transformation was 
proportionate to the degree of God's grace. The great growth in his spiritual life indicates the great amount of grace he had received. "I am what I am" not because of superior geneology, learning, status, prestige (Paul had all these), but because of God's grace.

To the apostle Paul, God's grace was no abstract idea. It was as real as his physical persecution of Christ. Christ came to save sinners, and through the act of the incarnation he bore the sins of the world by His death on the cross. He was raised on the third day, which fact makes justification a reality. Those who are truly repentant, those who accept Him as their personal Savior will be cleansed by His blood. Then, through the abiding presence of the Holy Spirit, man lives out God's life within himself. Jesus did not die merely to forgive man's sin, to clean up his past, or to free hin from his guilty feelings. He died that sinners may be saved and then go on to manifest God's power in their lives. What wonderful grace this is indeed!

Paul appreciated this tremendous transformation in his life, and he expressed it in these words: "Wherein in time past ye walked according to the course of this world, according to the prince of the power of the air, the spirit that now worketh in the children of disobedience: Among whom also we all had our conversation in times past in the lusts of our flesh, fulfilling the desires of the flesh and of the mind: and were by nature the children of wrath, even as others. But God, who is rich in mercy, for his great love wherewith he loved us, even when we were dead 
in sins, hath quickened us together with Christ (Eph 2:2-5)." From this point onward, Paul lived with Christ, he worked with Christ. Loyalty, faithfulness, self-sacrifice, steadfastness characterized his life. We admire, and are amazed at what Paul accomplished, but he directs our attention to God's grace. He knew that whatever desirable qualities he might possess they all had their source in divine grace. He was saved, chosen, appointed to preach by this grace. He had nothing to offer; he only had gratitude.

Thus, Paul realized that God's grace is not merely His favor toward those who might merit His approval, but, rather, it is His unlimited, al1-inclusive, transforming love toward sinful men and women. God loves the unlovable sinners and this is good news! What religion offers this kind of gospel? I need it; you need it; everyone in this world needs it. The world has tried to use science, education, and technology to improve man's conditions and to elevate his moral conduct, only to be disillusioned. Mankind is in an extremely unhappy state of disappointment, disillusionment, and moral bankruptcy. This is the very time when we need to personally appreciate what God's grace can do for us individually that we may have heavenly peace and joy while living in this sinful and sorrowful world.

II. "His grace which was bestowed upon me was not in vain.". Paul went a step further in asserting that God's grace was not bestowed upon him in vain. He was thrilled at the thought that His grace was consequential--influential--in his own life. It was not merely a negative, sin-forgiving act, it was a positive, 
Iffe-transforming power. A man who truly accepts God's grace can never be the same again. He who is reconciled to God may not have the guarantee of an easy, prosperous, trouble-free life. On the contrary, Paul's life appeared to be more troublesome after his conversion. But through it all, the greater the hardship the more he appreciated God's boundless grace and power. He was able to say, "I know how to be abased, and I know how to abound: every. where and in all things $I$ am instructed both to be full and to be hungry, both to abound and to suffer need. I can do all things through Christ which strengtheneth me" (Eph 4:12-13).

For Paul, God's grace was his source of strength. At the beginning he felt that the thorn in his flesh was a hindrance for greater service in God's cause. So three times he pleaded with God to have it removed. But the Lord answered, "My grace is sufficient for thee; for my strength is made perfect in weakness". (II Cor 12:9). This may not make sense to the average person. Paul's pleadings did not result in having the thorn removed. However, through this thorn in his flesh, he was enabled to fully utilize and deeply appreciate God's grace and its power, to walk close to Him, and to enjoy an abundant, victorious life. He was prepared to be submissive to God's plan, and in so doing received. His bountiful and al1-sufficient grace in all of his experiences. Paul's spiritual 11 fe was rich and enriched.

Some one said: "The inward strength to endure is a far higher manifestation of the divine grace than mastery of the outward difficulties of life. Outwardly a man may be torn, worn, 
wearied and almost broken, yet inwardly it is his privilege--in Christ--to enjoy perfect peace."

I know a sister in the church who was going through an experience which every wife dreads. Her husband was seldom home, he became unfaithful to her, and he was talking about getting a divorce. She loved her Lord, her husband, and her children. She tried her best to endure in order to save her marriage. Some who knew her thought that she would blame God and give up her faith. But praise God that this sister could manifest peace in her face when she said, "Every day God's grace embraces me, He helps me to trust in His promises. I blame no one, because these experiences have brought me closer to my Lord than anything I have ever experienced before. My heart is sad, but strangely I am tasting the kind of peace that I have never before tasted. Regardless of how my husband treats me, I can pray for him!. I feel that I am ready to meet my Lord whenever He returns. I have never felt just like this. I want to make good use of every opportunity to share His grace." Here is a Christian paradox: occasions of weakness may be transformed into occasions of strength, and defeats into victories.

This must be applied to our daily lives. What is your thorn in the flesh? Is it in the form of marital problems? Is it some difficulties in your job? Is it some besetting sins in your life? Whatever it may be God's amazing grace will be effective. It will enable us to feel like Paul that God's grace is indeed sufficient. 
Sometimes God permits seemingly unbearable trials to come our way. His purpose is to reveal our weaknesses--our needs. Trjals come to encourage us to learn to draw from God's inexhaustible reservoirs of divine grace. Therefore difficulties, hardship, insults, emergencies, and afflictions that come to us are, in fact, precious opportunities afforded us to experience God's amazing grace.

III. "I labored more abundant1y . . yet not I, but the grace of God which was with me."

As Paul received and experienced God's grace he gradually perceived the fullness of God's intention in dispensing His grace to him. It was not for Paul's personal benefit only. True, God loved Paul as an individual; Christ would have come to die for just Paul had he been the only sinner on earth. However, the most basic principle of Christianity is the principle of sharing. We are to give freely that which we have received freely. Jesus came to this world in order to share. God intended that after Paul had received His grace, he was to go out to demonstrate its effects so that others may be drawn to His grace. Paul was willing to labor more abundantly, compared with other apostles, because God's grace was with him. "The Holy Ghost witnesseth in every city, saying that bonds and afflictions abide me. But none of these things move me, neither count I my life dear unto myse1f, so that I might finish my course with joy, and the ministry, which I have received of the Lord Jesus, to testify the gospel of the grace of God" (Acts 20:23-24). He was not satisfied to be at the 
receiving end only, but he wanted to be a channel through which others might obtain God's grace.

Paul unmistakably attributed his zeal, his labor, his talents, indeed, his all to God's abiding grace in his life. Most of all, he desired that all. men might possess this marvelous grace. This accounts for the patience, tirelessness, perseverance, and persistence which characterized his labor. His one and only consuming desire was to save more, even a few more, people. He testified this desire in these forceful words: "And this I do for the gospel's sake, that I might be partaker thereof with you" (I Cor 9:23).

Paul found his purpose in 1ife; he knew to what mission God had appointed him. Thus, he was instrumental in consolidating the early Christian church. He not only suffered for the gospel work, but eventually he died for its sake. Paul's life experience offers one of the best examples of what a sinner can become by the transforming grace of God.

So many people are still alienated from the gospel of Jesus Christ. Untold millions are still sitting in darkness. Are these phenomena the result of our failure in truly receiving, experiencing, and appropriating God's grace? This very same grace which changed Paul so completely is waiting to effect the same transformation for each one of us. Christ's ministry, His death, and His resurrection which Paul preached were not interesting stories or fascinating theories; they were something that physically and realistically took place, in his life. From the time of his 
conversion onwards, his life was a living witness for the gospe1. To the apostle Paul, Christ's resurrection was not merely a historical event, it was an undeniable, unforgettable happening which he himself experienced. For Christ was resurrected in his own heart (Ga1 2:20).

The grace of God can do the same for you and for me, and He is most anxious to do this for us. He who was so gracious to Paul is still the same gracious Lord today. The power of God's grace to transform has ever been the same. Are we willing to come before our gracious God that we may experience the sentiments of this great hymn:

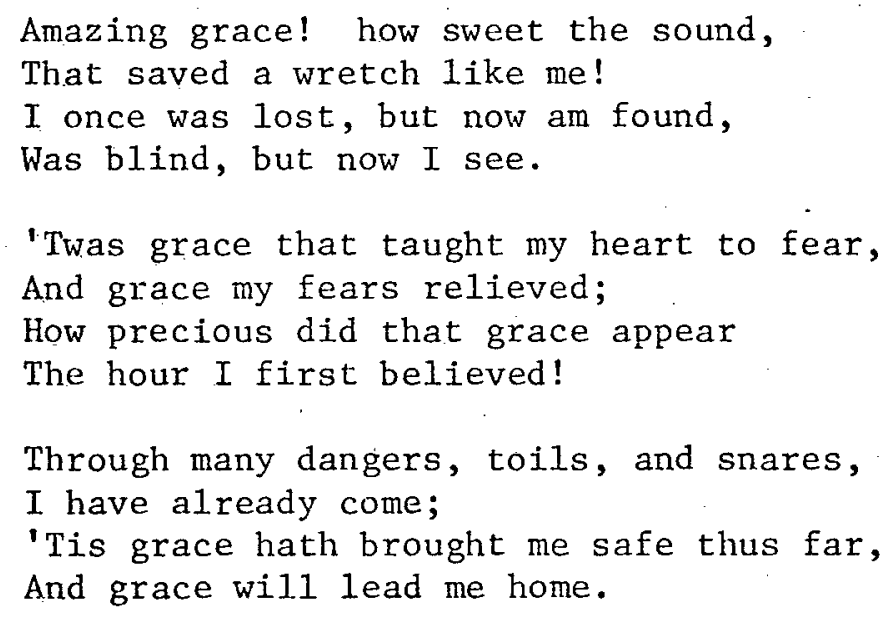




\section{APPENDIX C}

PORTION OF A SYJLABUS FOR THE TEACHING OF HOMILETICS

AT TAIWAN ADVENTIST COLLEGE 


\section{Bible, the Preacher's Source Book}

\section{Purpose of Study}

To establish the Bible as the best source for sermon materials and to give it its proper place in Christian preaching.

\section{Study Outline}

I. The sermon may have its beginning in any of five broad areas: (See H. C. Brown, Steps to the Sermon, pp. 30-42).
A. The Bible.
B. The congregation's need--the experience of the people.
C. A planned program of preaching.
D. The preacher's personal contacts and resources--the preacher's own experience.
E. Flashes of inspiration.

II. The Place of the Bible in Preaching. (See Chapter II of this paper).
A. The Bible is the best source and fountainhead of Christian preaching.

1. The Biblè, God's message to man (Heb 1:1).

"No man has a right to stand before a congregation to preach in the name of the Lord if he does not have a message from God" (I. H. Evans, The Preacher and His Preaching, p. 75).

2. The Bible, the Word of God.
a. 2 Ti $3: 15-4: 2$; Heb $4: 12 ; 2$ Cor $2: 17 ;$ Mk $7: 13$;
1 Pe 1:23-25; Rom $10: 17 ; 1$ Th $2: 13$
b. Preach the Word (2 Ti 4:2).
Our sermon must be based on the Word of God.

3. The Bible claims to be an authoritative book and a reliable guide to the true knowledge of God and His plan of salvation (Jn 5:39; Mt 4:4; 1 Cor 15:3,4). The Bible is the language of the Christian faith, and the only language that the church has ever used--1iving language. The appeal of the Bible is universal (Mt $28: 18-20)$. 
4. The Bible has an unequaled spring of variety and freshness. It shall stand forever (Is 40:8). "The Bible itself is a book of varied literary form and tends to yield variety in the presentation of truth" (Perry, Lloyd M., Manual for Biblical Preaching, p. 7).

5. Life and Power in the Word.

- In 5:24, 39; Jn 6:51, 63; Lk 1:37; Ps 119:152.

The Holy Scripture is the living word of the living God. Absorbed and personified in human flesh, this word has life and power in it.

- In 1:1. Christ was the 1iving word.

6. More and more Light.

- Ps 119:105, Pr 4:18

"The Word of God is not doctrine alone. It is more. The purpose of the Holy Scripture is to reveal God to men. The Holy Scriptures are given that man may know God, and by knowing Him become changed from what he is by nature into one who loves righteousness and desires to be Godlike in character and $1 \mathrm{ife}$ " (Evans, Preacher and His Preaching, p. 82).

7. "Since the Bible is God's unique communication of Himself and His truth to men, and is the highest and holiest source of truth, light and power, there is no reason for preachers to depart from Bible preaching" (Perry, p. 7).

B. The Bible bears witness to Jesus Christ.

1. Bible testifies to Jesus as the unique Son of God ( In I: $14-18 ; 3: 16,18 ; 13: 3 ; 17: 5$ ).

His crucifixion-1 Cor $1: 22-23 ; 1: 18,24$; Rom 5:8, 9 . His resurrection- 1 . Cor 15; Mt 28:1-10.

His mediation--Heb $4: 14-16 ; 10: 12 ; 1$ Jn $2: 1,2$.

2. Bible proclaims Christ as the exalted and determinative person in all creation and history (Php 2:11; Jn 14:6; Eph 4:11-12; Jn 17:24).

3. Bible makes the emphatic claim that Jesus is both present and coming (Mt 28:20; Jn 14:3; Heb 9:28; Col 3:17;

Php 4:13). 
C. The example of Jesus.

1. Jesus taught as One having authority. He believed and taught the infallibility of Scripture (Mt 7:28, 29; Mt $5: 17,18 ; 15: 3)$. To Jesus the Scriptures were the ultimate word in spiritual matters (Lk 16:31). Even when He had risen from the dead, He still appealed to the Scriptures for demonstration of His mission and divinity (Lk 24:27).

2. In Jn 5:39 Jesus bids us "Search the Scriptures." In that wonderful prayer recorded in John 17, He said, "I have given them Thy Word"--the duty of every minister of the gospe1; and He followed this statement by two commendations of the word: "Sanctify them through Thy truth; Thy Word is Truth."

3. "In all of His public utterances, Jesus upheld the Scriptures, and thereby strengthened faith in them as the rule of life. (Lk 11:28). At every opportunity, when an interest was awakened by friend or foes, He sowed the seed of the word" (E. G. White, Christ's Ubject Lessons, p. 39).

D. For the Preacher

1. It establishes authority for what he preaches. If we would speak to men in the name of God, which alone is true preaching, we must speak out of the Bible.

2. It gives direction and meaning to his sermons. The Bible is the preacher's charter. The Word of God must be the guide for the preacher.

"Great men are often biased, but the scriptures never. The Word of God must be the guide for the preacher; and if he follows it, he cannot go astray. But failure here will be followed by confusion" (P. H. Anderson, Christ's Preacher, p. 13).

3. It empowers his preaching:

- Heb. $4: 12$

- A living seed ( 1 Pe 1:23), a word of life (Jn 6:63).

4. It provides an exhaustless source for sermon materials (Merrill F. Unger, Principles of Expository Preaching, pp. $27,28)$.

"The Bible is the great inexhaustible reservoir of Christian truth. The daily reading of it will insure the preacher an unfailing supply of pulpit themes for the edification of his people, and an abundant source of illustrative materials" (Charles W. Koller, Expository Preaching Without Notes, 
p. 45). The Bible contains the most vivid, dramatic, and arresting material the preacher can use.

5. It challenges personal intellectual and spiritual growth. It makes the wealth of life continuously available for the needs of present life.(Ps. 119:130, 72).

6. It guides a preacher to be true to his calling ( $\mathrm{Jn}$ $21: 15-17$; Acts $20: 28 ; 2$ Ti $4: 1,2)$. It promises not only freedom from sin, but life eternal in a world purified from the effects of sin. It adds depth, dignity, and dynamics to his calling (see Kurtz's note p. 1).

7. It contributes to a wel1-rounded ministry. He [the minister] and his people survey the entire range of divine truth, from Genesis to Revelation (see Kurtz's note p. 2).

E. For the People

1. It meets human need with Divine help.

The word is sharper than a two-edged sword, but it is also broad enough for the whole of man and all of humanity (see Unger, pp.' 28, 29).

2. It expresses the will of God for the individual.

The Bible is all-sufficient in speaking to the great question of human life.

3. It opens the way for the closer operation of the Holy Spirit:

, 1 Th $1: 5,6$.

4. It furnishes a foundation for all spiritual growth, spiritual food (Rom. 10:17).

5. It meets the expectations and needs of the parishioners.

a. It stimulates personal Bible study.

b. It trains the church for its work, (1 Th 1:7, 8).

c. It creates a common bond of fellowship between believers (See Kurtz's syllabus, p. 2).

IIT. Biblical Authority.

"No man can preach with conviction unless he has an authority for that conviction. This authority is absolutely necessary if he is going to believe that which he is preaching, and if his hearers are going to accept that which he is preaching" (David W. Yohn, Contemporary Preachers, p. 102). 
A. Preacher must ground his authority in the place from which his message springs--its first and last authority in a real sense--Scripture. It is only in the Bible that we find a ground for authority higher than that which man can himself construct, himself deliver, and himself reject (p. 103).

B. The authority of Christ is dependent upon the authority of the Bible, because it is through the Bible that we have come to know Christ. The tangible and apparent authority for the church and its preaching is Scripture, which reveals Jesus Christ, who is the continuing authority for all faith. The authority of the preacher is not derived from denominational traditions but from his relation to and dependence on Scripture (p. 108). The authority of Protestant Christian preaching is Scripture (p. 112).

C. The Person and place of Jesus Christ in relation to the authority of the Bible. The Bible is a unity addressing itself to one point of reference, Jesus the Christ (p. 122). If the Bible is going to speak authoritatively, it must speak its witness to Christ. In reality it is Christ who is speaking with his authority through Scripture. The Bible can carry no authority whatsoever aside from the authority of Christ (p. 123). Mt 28:19, Christ is the "one center and essential content" of Scripture. Remove christ, and we remove the authority of the Bible (p. 124).

There is no alternative source from which the redemptive activity of God in Christ can be known, other than the Bible. The authority of the Bible is the authority of the content of its message, Jesus Christ.

D. God has called us to deliver the gospel to men. We have no authority within ourselves. Our authority is Holy Scripture as it relates Christ and the church to the believers. When we preach Scripture we preach an authority that is external to us. It is an authority that is above us. If our lives are spent in anything other than complete dedication to our source of authority, Scripture, then we have failed our calling ( $p .129$ ).

E. Since the on $1 y$ authentic document for authoritative content about God in personal revelation is the Bible, the task of the preacher is to use the Bible correctly in sermon preparation and delivery (H. E. Brown, A Quest for Reformation in Preaching, p. 350). The authority of the prophets and apostles resided in their fidelity in witnessing to God's revelation and especially to Jesus Christ (1 John 4).

Biblical authority and preaching should be correlated (Brown, p. 35). 
F. For the preacher this reassertion of the Bible's authority is both bondage and liberation. The ministry is a life-long struggle against the temptation to liberate ourselves from the Bible. We are always on the point of finding a better word to speak than the word that speaks through this book (Douglass, Preaching and the New Reformation, pp. 34-35).

IV. Characteristics of Preaching from the Bible.

A. Biblical preaching is faithful to the revealed truth of the Bible.

1. It is based on the Word of God.

2. It seeks to handle aright the Word of God. A sound biblical sermon demands a valid hermeneutical base.

B. Biblical preaching has the same living message as the Bible has for men.

1. It is the proclamation of the gospel either explicitly or implicitly.

2. J.t is a given message by Jesus Christ and exalts Christ.

C. Biblical preaching is empowered by the same living spirit as that of the Bible.

1. It is sensitive to His leading and discovers ways of entering into a cooperation with the promised Holy Spirit.

2. It leads men to Jesus Christ.

D. Biblical preaching is presented in a Christlike spirit and manner.

1. It is directed to meeting the needs of contemporary life and concern for persons (Mt 9:36).

2. It is interesting and contains spiritual food for every age level.

E. Biblical preaching is not stereotyped but admits various approaches.

v. Conclusion

The Bible is the best primary, indispensable source for the origin of the sermon idea. It has a message from God and a meaning for the totality of man's 1ife and history today, both personal and corporate. True preaching cannot exist apart from the Word of God (Rom 10:17). 
Choosing the Text

Purpose of Study

To select the right text for the sermon.

\section{Study Outline}

I. Definition of the Term.

A. The word "text" is derived from the Latin texere, "to weave, to put together, to construct, hence to compose."

B. The noun textus or textum denotes the product of weaving, the web, the fabric.

C. It is that out of which the sermon is woven, the basis of the sermon or message, the portion of Scripture chosen as the suggestion or foundation for the sermon.

D. The text is not to be a mere motto for a sermon, nor is it to be chosen after the theme or subject is chosen and the sermon finished.

II. Advantages of Having a Text.

The sermon which rightly uses a text is always superior to the sermon which uses no text. Taking a text of Scripture at the opening of the service has many advantages.

A. Advantages for the preacher.

1. It gives the preacher authority and boldness in the proclamation of His message. It shows that the preacher respects the Word of God, that he is in earnest, and that he has an important message from God.

"With a 'Thus saith the Lord' as the basis of his sermon, he may speak with the authority of Heaven, for after all, i.t is God and not man who speaks from the text. With such an authoritative message no preacher need be timid about proclaiming the will of God. . . . To be sure one has a direct message from God gives the messenger a sense of authority and holy boldness" (William Evans, p. 22).

2. It will keep the preacher's mind from wandering. It 1imits the sermon. It gives the sermon point. The preacher is kept in line, he cannot deviate from the true cause. "A we11chosen text presents one grand Biblical idea" (Lenski, p. 11). 
3. It provides the substance of a sermon. The text should be the foundation of the sermon and may be illuminated by other scriptures. The preacher's text gives him God's view on his chosen theme. "A real text prevents the sermon from degenerating into a lecture" (Lenski, p. 11).

4. It will keep the preacher Biblical and he will become the servant of the word. It affords opportunity of explaining and impressing some passage of Scripturé.

"It almost invariably enriches the sermon from the wealthy life with God in the Bible with suggestions which were not in the preacher's mind before" (Broadus, p. 17).

5. It seeks the guidance of the Holy Spirit. It will lead the preacher to seek the Lord in earnest prayer that the Holy Spirit may dwell in his heart. The atoning blood of Christ will make him clean in God's sight, so that the Holy Spirit may guide him as it controlled holy men of old who wrote the Word of God.

B. Advantages for the congregation.

1. The text awakens the interest of the congregation, since it comes to them as a voice from another world; it solemnizes the mind and commands the attention.

2. It fixes in mind the theme of the sermon. The congregation generally can remember the text longer than the comments on it (I. H. Evans, p. 157). It also aids the hearer to remember the train of thought, if, in fact, the sermon has really evolved from the text (Broadus, p. 17).

3. It helps and satisfies the spiritual need of the congregation. They are fed by the living Word of God if the text has a direct bearing on the theme for the hour and is not something snatched from its natural setting and its real intent.

III. Rules for the Selection of a Text.

A. General rules which govern the choice of a text.

1. The constant reading of the Word of God is primary.

"The Bible is not merely a textbook, it is a book of texts. It contains the truths we have to teach, the laws which we have to illustrate in their relations to the lives of our people, the divine promises by which we are to console them when in trouble and to strengthen their faith in the love and power of God" (W. Evans, p. 26). 
2. The guidance of the Holy Spirit is paramount. The preacher should seek the Spirit's guidance. The man who is continually living under the influence and power of the Holy Spirit will scarcely ever be at a loss for something to preach about.

3. There should be a careful consideration of one's ability to deal with the text and the subject derived from it.

"It is not well for David to go to battle in Saul's armor. A preacher must not choose subjects that are above and beyond his ability to handle. Before he preaches on a subject he must understand clearly for himself whatever phase of it he may present" (W. Evans, pp. 25-26).

4. He must carefully consider the spiritual needs of the people to whom he is ministering. Jesus said, "I am the good shepherd; I know my own and my own know me" (Jn 10:14).

"Do not serve strong meat where the milk of the Word is in place. Shoot too high, and though you shoot so well, not a heart may be touched. . . Choose the text from the pew side, not from the library and study side" (Lenski, p. 26).

"The preacher should study his people. He must consider their needs--physical, mental, moral, spiritual. He should ask Himself what he has found out about their needs as the result of his visitation among them. Let him imagine his people gathered around his desk as he considers what to preach about, and let their needs determine what shall be the nature of his text and sermon" (W. Evans, p. 24).

5. There should be a careful consideration of the cycle of truth preached.

"Do not habitually neglect any portion of Scripture. . . In the course of a good many years a preacher ought to have taken some texts from every portion of Scripture" (Brown, p. 21).

"He must ask himself, 'on what themes have I been preaching lately? Have I omitted any of the great doctrines of the Scripture? Has my preaching been symmetrical, and has it included the whole counsel of God?' The choice of a text and a subject is not something that can be left to change or to the whim of the preacher" (W. Evans, p. 25).

B. Some considerations which govern the choice of a text. 
1. Caution should be exercised in choosing texts that will seem odd.

"The text should indicate not only a central concern of the message but something of its tone also. It should embody or suggest qualities of thought and emotion that may with profit be sustained and advanced as the message unfolds". (Broadus, p. 20).

2. The text should not be obscure. It ought to exhibit its meaning readily. Always prefer lucid texts. Discard dark and difficult texts.

3. The sayings recorded in Scripture of uninspired men ought not to be used as texts, unless we know from other teachings of Scripture that they are true, or we propose to find instruction in the fact that those men made the statements given, or that the statements are untrue (e.g., $2 \mathrm{Ki} \mathrm{18)} \mathrm{(Broadus,} \mathrm{pp.} \mathrm{22-23).}$

4. Weigh texts for thought content and outline value.

5. Select texts which develop the proposition of the sermon.

6. Consider personal reactions and responses to the text.

7. Seek for variety.

8. Fear not the familiar.

9. Use brief texts that stimulate interest. (The short text has too many advantages to ignore.)

10. When historical texts are chosen, the story must be fully told.

IV. The Text and the Sermon (See Lenski, pp. 35-43).

Soundness of view in regard to the connection between the text and the sermon helps to clear up many other questions pertaining to the text and will certainly clarify one's idea of what a sermon ought to be.

A. The ideal relation between the text and the sermon should lie exactly mid-way between too loose and too close.

1. If the sermon is in any way independent of the text, the relation is decidedly faulty. If the text degenerates into a mere pretext it is better to preach entirely without it. 
2. A mere commentary of the text is not a real sermon. Even if the exegesis is sound and thorough, a sermon that goes no farther is a failure. The tie between text and sermon is too close.

3. In the sermon the preacher should look through the text at his congregation. The more he succeeds in that the truer will be the combination of his text and his sermon.

B. How to get the right relation between the text and sermon.

1. Be faithful to the text.

By reading a text in the pulpit the preacher virtually promises that he will preach on that text.

2. Exhaust the text.

a. The main thought of the text is to be the main thought of the sermon, and not some side thought, some fragment, some tatter of the text.

In getting at the main thought do not be satisfied with broad generalities. Discover what is distinctive in it, peculiar and different from other and similar texts.

b. All the essential points of the text should find their corresponding place in the sermon. Take your text apart. Lay each piece out before you. See how each part is related to the center.

c. Nothing of real importance in the text should be omitted in the sermon.

3. Adapt the text to the needs of the hour.

This does not mean that he alters anything in the text. He does not press a word or thought in it beyond its native meaning. He reads nothing into the text. Homiletical adaptation dare not degenerate into exegetical or homiletical falsification.

a. Adaptation is the effort to get out of a text the very things needed for a congregation at the time. It answers the question, what does this text say to me and my people today?

b. Adaptation takes into account the specific purpose the text is to serve.

The preacher should have fully mastered that text and its real contents. He also ought to know the needs of his hearers. 
If the preacher knew his congregation as he should he could offer it Christ, the divine grace, the quickening, healing, strengthening Gospel in his texts.

c. Poor and faulty text adaptation helps to empty the pews. Masterly adaptation has the opposite effect.

V. Edmund P. Clowney, citing J. Van Andel, an old Dutch preacher, has reminded us that "the pulpit must not drive us to the text, but rather the text must drive us to the pulpit (Preaching and Biblical Theology, p. 19). 


\section{Interpretation of the Text}

\section{Purpose of Study}

To determine the principles for the use of Bible texts.

\section{Study Outlines}

I. Mastering the Text Is "Must" for a Biblical Preacher.

A. A good deal of the weakness and ineffectiveness of a sermon is due to insufficient and improper study of the text.

B. Some ministers rely on their gift of eloquence. This is not to be despised, but eloquence must work with the proper material. Give eloquence the fullest, richest, and very best material.

c. Some rely on their general knowledge of the Bible and of the doctrine of the gospel for success in preaching. This is necessary and helpful. Yet mere general knowledge raises the preacher but little above the commonplace.

D. Some rely for their success in preaching on material drawn from extraneous sources, such as books with illustrations and anecdotes. Most important are a keen eye, a keen ear, and an understanding heart that sifts, tests, and works up what it sees and hears. All that is thus acquired is not to be used as a substitute for text mastery, but as a supplement to the most precious material gained by such mastery.

E. A substitute for real text mastery has never been found. To interpret and apply his text in accordance with its real meaning is one of the preacher's most sacred duties. He should honestly strive to understand that which he interprets and give forth its real meaning and no other.

II. Chief Sources of Error in the Interpretation of a Text.

A. Misunderstanding the phraseology of the text itself.

1. Make earnest efforts to ascertain the true meaning of the text--know the meaning and significance of its words, the relation of the words to each other in the passage, the grammatical relations within the passage, and the mood and spirit of the passage.

2. The interpreter of Scripture must remember that he is interpreting a literature whose style reflects the modes of thought of each of the epochs represented in it and of each of the authors who contributed to it. 
3. Example--Jer. $3: 4$.

B. Disregarding the connection of the text.

1. A sentence taken away from its connection would give a positjvely wrong sense (e.g., 2 Cor. 12:16).

2. Reasons for often neglecting or knowingly violating the connection of a Scripture text:

a. Wide spread practice of allegorizing.

b. Excessive use of short texts.

c. Carelessly made divisions that sadly disregard the connection and obscure the sense.

3. Example: 1 Cor. 2:9 is not referring to the glory and blessedness of heaven; but the connection leaves no doubt that the apostle refers to the profound wisdom of the plan of salvation.

C. Improper Spiritualization.

1. Exercise sound judgment and constantly keep in mind that the parable is an illustration and founded on some resemblance or analogy which is at best only partial.

2. Example: Amos 6:1 "Woe to them that are at ease in Zion." This is applied to man's reliance upon human instrumentalities or outward agencies instead of relying on God. The donothing members of a church deserve severe scourging, but this text does not touch them. Ex. 2:9 is used in preaching to parents or teachers. God does not address these words to anybody.

III. Principles of Interpretation.

A. Begin with prayer.

The right understanding of the Word, or of any part of the Word, is a gift from above.

"Diligent prayer is more than half the study"--M: Luther. The prayerful attitude must permanently fill the heart.

B. Let the text act directly on heart and mind.

Take the text before you and read it with all your mind and heart centered on its every word. With your mind saturated with the text at first hand. 
C. Ascertain whether the 1anguage of the text is literal or figurative.

Usually the Bible interprets its own terms and, by means of the context, informs the reader whether the language used is to be taken in a literal sense. It is necessary to examine the passage in all its details, critically, exegetically, and faithfully. The literal language of Scripture is to be preferred unless otherwise demanded by the context, parallel passages, or analogy.

D. Ascertain the meaning of words as used by each writer of the Scriptures.

All the writers do not give the same word exactly the same meaning. The usage of the writer and the connection in which it is used must determine the meaning of the particular word.

E. Consider the circumstances peculiar to the writer and those to whom he was writing to:

1. Get acquainted with the individuality of each writer, his style, and mode of expression.

2. Understand under what circumstances the words were written.

3. Understand the character of the people to whom the words were addressed.

4. Learn state of moral sentiment which prevailed at the time of writing.

F. Compare Scripture with Scripture (Rom. 12:6).

"Make the Word of God as much as possible its own interpreter. You will best understand the Word of God by comparing. it with itself, comparing spiritual things with spiritual" (Bishop Newton).

G. Understand the unity of Scripture.

There is no basic disagreement between the theology of Paul and the theology of James. The same Holy Spirit guided all the Bible writers. Despite their individual differences, a fundamental oneness persists.

H. Study the text itself.

Find out what the text itself really teaches. The preacher owes diligent and thorough study of the text to God, to the Scriptures, to himself, and to the people to whom he ministers. 
1. Lexical study--examine key words in the passage.

2. Grammatical setting--examine the word in its sentence.

3. Find out the exact meaning of each word, phrase, and sentence.

I. Note the context.

The context is what goes before and what follows after the special portion of the sacred text under consideration.

1. See the text in its larger setting.

2. Search for the meaning of the passage in jts historical setting.

3. Consider the passage in terms of the total biblical viewpoint.

J. Make use of parallel passages.

"Particular diligence should be used in comparing the parallel texts of the old and New Testaments. It should be a rule with everyone who would read the Holy Scriptures with advantage and improvement, to compare every text which may seem either important for the doctrine it may contain or remarkable for the turn of expression with the parallel passages in other parts of Holy. Writ" (Horsley).

K. Use resources outside the text.

After the student has carefully and prayerfully studied the text, the context, and the parallel passages, he may safely read what other people have to say on the text. The resources outside the text include commentaries, text expositions, word and subject indexes, and other literary helps.

IV. The Steps in Interpretation (see Brown, Steps to the Sermon, pp. $54-60)$.

A. The text and its historical background.

1. The author and his situation: mental habits, character, environment.

2. The readers first addressed by the author: mental habits, character, environment.

3. The occasion and purpose of writing. 
4. Geographical, political, economic, and social conditions reflected in the passage.

B. The text and its context.

1. The immediate context.

2. The remote context.

3. The larger context of the development of thought in the Bible itself.

c. The text and its analysis.

1. Kind of language: prose or poetry; literal or figurative.

2. Significance of words: meaning from lexicons; its use in other passages.

3. The relation of the words to each other in the passage: grammatical relations and tenses.

4. The mood and spirit of the passage:

D. The Text and ts ruths.

This step is to draw truths and applications from the passage.

1. Doctrinal interpretation.

State the central truth of the text and list the truths involved in it.

2. Practical interpretation.

List the possible applications of the passage to the needs of the people.

V. "To interpret and apply his text in accordance with its real meaning is one of the preacher's most sacred duties" (Broadus, p. 24).

Serious and eternal issues are involved in the proclamation of this truth. Lives of men today and eternal destiny tomorrow depend upon accurate and effective interpretation of the truth of God as revealed in Scripture (Brown, p. 47). 


\section{Christ, the Central Theme in Preaching}

\section{Purpose of Study}

To know that Christ is to be the central theme in all biblical preaching.

\section{Study Outline}

I. Why Christ Should Be the Central Theme in Preaching

A. The rule which the Scripture lays down for preaching (1 Pe 4:11).

1. "The innermost secret of effective preaching is to present Christ and His atonement for sin. This is to be the one supreme burden of all that we preach to men" (Haynes, p. 71).

2. 1 Cor. $2: 1-5$.

There is a complete summary of gospel preaching. Its character is that of the testimony of God. Its doctrine is Jesus Christ and Him crucified. Its spirit is that of conscious weakness and humility. Its form is not of human wisdom. Its power is in the demonstration of the Spirit. Its effect is the establishment of faith upon God's foundation (Haynes, pp. 71, 72).

B. The only way of preaching God has promised to bless.

1. "Theoretical discourses are essential, that people may see the chain of truth, link after link, uniting in a perfect whole; but no discourse should ever be preached without presenting Christ and Him crucified as the foundation of the gospel. Let the science of salvation be the burden of every sermon, the thene of every song. - . Bring nothing into your preaching to supplement Christ, the wisdom and power of God" (Gospel Worker, pp. 158,160$)$.

2. "A11 the principles and duties of the gospel bear a more or less direct relation to Him" (Haynes, p. 72).

3. A sure guarantee of success for every laborer.

"If through the grace of Christ His people will become new bottles, He will fill them with the new wine. God will give additional light, and old truths will be recovered, and replaced in the frame work of truth; and wherever the laborers go, they will triumph. As Christ's 
ambassadors, they are to search the Scriptures, to seek for the truths that have been hidden beneath the rubbish of error. . . . One interest will prevail, one subject will swallow up every other Christ Our Righteousness" (R.H. Extra, Dec. 23, 1890).

C. A11 truth embraced in Christ.

1. "Jesus Christ and His atoning work is the center of a widely extended circle which embraces our whole relationship to God, everything that is profitable to men" (Haynes, p. 74).

2. "The Scriptures are the circumference of faith, the round of which it walks, and every point of which compass it toucheth; yet the center of it is Christ. This is the polar star, on which it resteth" (Matthew Henry).

3. No truth can be properly understood except in the light of His atonement. No man has a proper comprehension of any teaching of Scripture unless he views it in this divine light.

D. The preaching that will finish the Gospel.

1. We shall not accomplish our supreme task in this world by any other means than by this preaching:

"The world will not be converted by the gift of tongues, or by the working of miracles, but by preaching Christ crucified" (Testimonies to Ministers, p. 424).

2. This is to preach the threefold message effectively (Rev. 14:6-12).

"Where the people assemble to worship God let not a word be spoken that shall divert the mind from the great central interest--Jesus Christ, and Him crucified. The third angel's message is to be our burden of warning. The side issues are not for us to meddle with" (TM, p. 331).

E. The sole purpose of preaching.

The sole purpose of preaching at all is to annource the word of reconciliation.

"There is no salvation in anything that you can herald to lost men and women unless you can kindle in their hearts faith in Jesus Christ as the Son of God, persuading them to accept Him as their substitute and receive Him as their mediator" (I. H. Evans, p. 91). 
"We are urged to present Christ in His fullness both in the churches and in new fields" (GW, p. 30I).

F. Preaching Christ amidst the crisis (1 Cor $1: 23$ ).

1. The church entrusted with the message (Evangelism, p. 16).

2. Our responsibility to show men of Christ's abiding presence, Jn 14:27 (Ev., p. 15).

3. The world's crying need.

"The world today is in crying need of a revelation of Christ Jesus in the person of His saints" (TM, p. 458).

4. Ambassadors for Christ in this crisis hour (Ev., p. 22). Christ's message alone can save the world. This is the only hope in the world's great crisis.

II. The Meaning of "Preaching Christ."

A. Preaching Christ is Evangelical power.

1. 1 Cor $2: 4,5 ; 1$ Cor $1: 24 ;$ Rom $1: 16$.

2. Christ's name brings power.

a. Preaching Christ confronts Satan's iies (Ev., p. 169).

b. Through Christ we can do all things (Ev., p. 98).

3. Christ's name brings victory.

a. In $: 12: 32$.

b. No better formula has ever been found.

In Christ alone is man's salvation. His name woos, wins, and attracts men.

Men controlled by Him, men who live only to lift Him up are men of power.

B. Preaching Christ in the message (1 Jn 4:14).

1. There is one central fact of all preaching. This makes the difference between life and death, eternal salvation and eternal loss. To preach that Name is the greatest privilege of man. (See Acts $2: 36,1$ Cor 1:23; $3: 11$, Mt $16: 18$ ). 
2. 2 Cor 5:18-21. This was all done for the sake of humanity.

There is no Christianity apart from the historical Jesus. Christianity becomes power only as Christ dwells in us and gives us of His victory (Gal 2:20).

3. Set forth Christ to the people as an adequate rememdy, as the only remedy, for all the evil in the world, the only: supply for the whole world's desperate need, the only hope of salvation from sin, the divinely appointed "way; the truth, and the Iife" (Haynes, p. 74).

4. How did Paul preach?

a. Paul was concerned about setting forth the duties of husbands in relation to their wives; but in doing so. he preached Christ (Eph 5:25-33).

b. Paul laid down the principles of church disciplin; but in doing so he preached Christ ( 1 Cor 5:1-7).

5. How did Peter preach?

a. To the believers scattered abroad, he was setting forth the duties of servants to their masters; but in doing so he preached Christ (1 Pe 2:18-25).

C. Preaching in Christ's own way (Luke 4:22).

Instead of discussing erroneous theories or seeking to combat the opponents of the gospel, why not follow the example of Christ? Fresh truth from God's treasure-house flashed into the minds of men as they listened to Him, and they were won for the kingdom of God. Peter said, "Thou hast the words of eternal life" (Jn 6:68) (Anderson, p. 194).

1. The way we present the truth determines success or failure.
a. The secret of success (Ev., p. 170).
b. The danger of weaving in human threads (Ev., p. 215).

2. Things Christ did.
a. Varied to suit his audience (Ev., p. 208).
b. Reached the heart (Ev., "p. 208).
c. Used illustrations (Ev., pp. 203, 123).
d. Spoke tenderly (Ev., pp. 174, 665). 
e. Studied the natural train of thought (Ev., p. 139).

f. Had tender compassion (Ev., pp. 124, 484).

3. Christ's way is one of sweetness.

a. Carried understanding sympathy of the people with him (Ev., p. 177).

b. Pictured green pastures (Ev., p. 189).

c. Presented one point at a time (Ev., p. 202).

d. Presented the truth in an easy style (Ev., p. 482).

e. Found a way to the heart (Ev., p. 483).

D. Preaching Christ is the third angel's message (Rev 14:6-12).

1. The great center of the message.

We are not merely commissioned to condemn, reform, expose error, preach ecclesiology, be students of history, and prophets of gloom. We are to be ambassadors of hope. We are to exalt Christ, show the way out of the labyrinth of confusion and show men how they can be saved (Eckenroth).

2. Our supreme task is to present Christ in His fullness--not only as Judge and coming king, but as a tender Shepherd who guides the wayward home. As our Intercessor at the throne of grace He waits only to forgive and forget (Anderson, pp. 194, 195).

3. The reason many churches die.

"Our churches are dying for the want of teaching on the subject of righteousness by faith in Christ, and on kindred truth" (GW, p. 301).

III. A Mighty Saviour (Heb 7:25).

A. Present Christ as the center of every theme. You do not have to take a text about Christ or preach only on Christ. It matters not what your text may be, if it is appropriate to your subject; you ought to study and pray that Christ Jesus shall be the drawing power, the magnet, in the whole discourse. - . Christ shall be made the center of it all, and shall be presented as the mighty Saviour, able to deliver. He must become the hope of every needy, hungry, sin-sick heart, and the eyes of all must look to Him, till men confess Him their Redeemer, mighty to save (I. H. Evans, pp. 99, 100). 
B. Paul met the stubborn resistance of his generation to Christ's kingdom by boldly proclaiming that Christ. In solving the problem of unbelief; in wrestling with wild fanaticism; in the denunciation of pagan debauchery and Jewish blindness, Paul found Christ to be the answer. The subduing of prejudices born of ignorance came about by preaching Christ. The preaching of difficult subject; the making plain of those truths that ran counter to the prevailing religious philosophies, were a1l easily handled by that great apostle by preaching the Saviour.

Not ourselves, but Christ Jesus the Lord (2 Cor 4:5).

The primary emphasis in preaching from a soteriological point of view is to be on God's gracious act in Christ for all man! 


\section{Biblical Preaching and Cultural Context}

Purpose of Study

To consider the relationship of biblical preaching and the cultural context in which the hearers are living.

\section{Study Outline}

I. Christian faith (message) is highly relevant.

A. Preaching the Gospel successfully depends on at least two factors.

1. One is communication, the ability to identify your audience and to place yourself in an effective position to reach them.

2. The other factor is the Gospel message, which must be thoroughly translated into terms meaningful to the hearers in their present situation.

B. The historical particularity and the cultural richness of the Bible--If the gospel is to be universal and eternal, it must have the ability to operate in all kinds of social structures. It must speak to the national situations of all kinds of communities at each period of history and be meaningful within the limitations of all social units (Alan R. Tippett, Church Growth and the Word of God, p. 28).

1. Cultural and historical differences did not prevent communication.

"The delivery of God's word extended over thousands of years of history, during which time the dominant social structure changed from patriarchal society to oriental monarchy to empire. . . . The word of God was relevant to al1 these situations" (Tippett, p. 28).

2. God's Word is not bound by time, place, or literary form.

"He who spoke within the varied social configuration of two thousand years of biblical history can speak to the nations today" (Tippett, p. 29).

3. Bible reflects vastly more of the culture in which it was born. 
"The very intention of preaching, as of the Bible, is engagement of men where they are. And where men are is culture" (Charles Rice, Interpretation and Imagination, p. 2).

The regular reader of the old Testament is frequently aware that God's word came through to people who lived and behaved within the limits of social patterns quite different from his own.

a. The interpretation of the ethics of Boaz' spreading his skirt over Ruth in the field (Ruth 3:6ff.) depends on an understanding of the social customs and laws of redemption within which this drama was enacted.

b. As for Assyria, apparently that nation could be saved without the necessity of changing its social structure. Repenting and turning to God would bring the promised salvation, even within the pattern of absolute monarchy (Jonah 3 ).

c. A phrase in Zephaniah speaks of nations worshipping God, "every one from his place, even the isles of the heathen" (2:11)--that is, each race within its own locale and cultural setting.

4. Christianity is a positive affirmation of faith in the validity of living in the world for the kingdom of God.

a. Jesus taught His disciples to pray for the kingdom's coming ". . on earth as it is in heaven" (Mt 6:10).

b. He thrust them into the world's darkness and unsavoriness with a charge to be "light" and "salt" (Mt $5: 13-14)$.

c. He challenged them to see victory, not defeat, in his decision to accept crucifixion ( $\mathrm{Jn}$ 16:33) and to have the courage to take up their own crosses and follow him in bringing redemption from God into the world (Mt 16:24).

II. Christ and Culture.

The Preacher has a special interest in the relationship between Christ and culture.

A. Incarnation.

1. "The incarnation of the Son of God ( $\mathrm{Php}$ 2:7-8) was within the social limitations of Judaism, even within a specific 
lineage within that nation. With respect to locale, it emerged within a normal Galilean village structure, within an occupational group in the peasant economy, where Jesus iived as a carpenter and the son of a carpenter (Mt 13:55; Mk 6:3) (Tippett, pp. 29-30).

2. Incarnation involved not only $\mathrm{His}$ own human nature but a specific culture as well, including an expression of His message in terms native to His Jewish people. When Christ preached and lived His Gospel, He inevitably "incarnated" His message in terms of the Jewish culture of which He was a part.

B. The Relevance of Christ's preaching.

1. "Although the preaching of Jesus possessed an amazing relevance for men in all ages, they were especially relevant to the people in their peculiar situation to whom he preached. His preaching was timely as well as timeless. . . Jesus brought his eternal and universal truth to the urgent issues that lay at hand and pressingly beset the men of his own race and time. . ." (Francis J. Handy, Jesus the Preacher, p. 120).

2. His speech followed the linguistic enclosure of his own people: He probably spoke in the Galilean Aramaic dialect (Mk 14:10).

3. Jesus was known as a countryman and was spoken of as the "prophet of Nazareth" (Mt. 21:10-11). Yet he was sent as the Father's herald to proclaim salvation to all (J.n $3: 16$ ).

4. Within the social enclosure of Jewish life, language, and custom, Jesus dealt not only with individuals, but with kin groups, both He and the Gospel writers recognizing their entity (MK $1: 19 ; \mathrm{Jn}^{-} 11$ and $12 ; \mathrm{Lk}^{-}$15:2; $\left.\mathrm{Jn} 2: 1 ; \mathrm{Lk}^{\prime} 8: 1 ; 10: 5,8-9\right)$.

5. Jesus had logical relatedness to the culture in which he lived; he accepted and sought to extend the highest moral, ethical, and religious insights of that culture.

III. The Relevance of Biblical Preaching.

A. Its importance.

1. Since the great commission was expressed in ethnic terms (M.t 28:19), we look forward to the Great Consummation when the gospel is to be preached to every "nation, kindred, and tongue" (Rev 10:11; 14:6). The redeemed will come from all "nations and kindreds and peoples and tongues" (7:9). 
2. The Bible recognizes that all social units are opportunities for the proclamation of the word of God. We ought therefore to be ever aware of the social units about us as groups that can be won to Christ. To this end Christ sends us forth into the world ( $\mathrm{Jn}_{\mathrm{n}} 17: 18$ ).

3. Each convert has an individual experience of salvation and he becomes a new man in Christ; but it does not demand that this must necessarily be identical with any western stereotype. It rather insists that the individual convert must be won for Christ, that he be a new man within his own cultural situation. We have seen converts so completely uprooted from their contexts and tradition, so foreignized, that they are left without a home, without a field for social interaction, and sometimes without a means of livelihood (Tippett, pp. 33-34).
a. Acts 15:1-35.
b. $J_{\mathrm{n}} 4: 26-41$.
c. Mk , 5:1-20.

4. "Let us view the human race, not as one vast field, a11 parts of which are planted to one crop, receive the same rainfall, and are equally fertile; but as a patchwork of kinds of soil--sandy and clay, fertile and unfertile, dry and wet, rocky or rich, planted to a great variety of crops in many different stages of ripeness. Christian preaching will be more successful as it proclaims Christ with a full and exact knowledge of the types of 1 and and kinds of crops" (McGavran, Church Growth and Christian Mission, p. 86).

5. Biblical preaching is concerned with how the message shall be focused for the people of our time.

The homiletical task, having the intention of meeting people at a particular time and place, leads us to be open to culture while being attentive to theology.

(Charles L. Rice, Interpretation and Imagination, p. 24).

B. Biblical preaching discerns these points of relevance and in doing so has recovered the authentic meaning of the biblical text (See Whitese11, The Art of Biblical Preaching, pp. 98-100).

1. Biblical preaching to be effective, must be pertinent, congruous, apt, suitable, relevant to modern moods, thoughtforms, and terminology. It must come alive if it is to make any impact on modern life. 
2. What can biblical preaching do to show the relevancy of the Bible to the twentieth-century living?

a. We can live in the Bible and learn its secrets and power for our own lives.

b. We can live with people, be concerned for them, and have compassion on them. We must come out of the ivory towers of inteliectualism and know the Bible fits our day as it has all days.

c. We can use our imaginations as we study and preach the Bible and let them relate the materials of the ancient past to the living present.

d. Let the Holy Spirit teach us the deep things of the Word, the hidden things of the Scriptures, the lifegiving truths that we must pass on to others if the word is to take hold of their lives.

e. We can make careful and conscientious use of the light and help afforded by the original languages, history, geography, archaeology, customs, and the commentaries.

f. If men can see the Christianity of the first century reduplicated in the lives of God's servants today, they will know that the Bible is relevant today, and they will wish to know something of its power for themselves.

g. The sermon must speak to the real needs of the church in a way that is understandable to those related to the church. The modern preacher has the task of witnessing to the fact that God's action is still a reality and not merely some once-and-for-all. event of long ago" (M. R. Abbey, The Word Interprets Us, p. 141).

h. "The fundamental question about the relevancy of our preaching has to do with its genuineness rather than with its contemporaneity. Does it deal with the essential stuff of human nature and the human experience? - . Do we impress the people with the feeling that we are dealing with trifles, or with blinding and appalling enormities? . . . Does it grasp the realness and the earnestness and innerness of human existence and does it to this existence bring a warning and a hope and a way which are something more than man's cheery encouragement to man? . . Make your preaching in this sense genuine and you will have no difficulty making it relevant. . . ." (Kyle Haselden, The Urgency of Preaching, pp. 100-10). 
i. When people become a major source of preaching, it takes on a new interest and even excitement. It comes from living with people. Living with people, both actually and in the social use of the imagination, to such an extent and so genuinely that they become a source of preaching, is for the preacher, kissing the earth, a deeply religious practice.

This sense of people helps to keep alive a constant remembrance of the burden and mystery of life (See Halford E. Luccock, In the Minister's Workshop, pp. 73-84).

j. All preaching worthy of the name must be contemporary and people oriented.

It must draw on ancient truths, to be sure, but it must be addressed to people who are living now in a real world and must deal realistically with their personal and social needs.

The great preachers have been relevant to their day. They spoke to the needs, the concerns, and the problems of the people who listened.

k. "The greatest need of our time is that of getting the gospel so interpreted and applied in the cultural process as to make its emphases truly live options" (Haskell M. Miller, A Christian Critique of Culture, p. 78).

IV. Understanding your cultural context (2 Tim 3:1-5).

The preacher is to help modern man to know who he is, to know God, to know what he is living for, and to accept his responsibilities under God in human society.

It is impossible to comprehend the standpoint of your congregation without a study of their particular cultures.

A. When the Apostle Paul was in Athens he noticed an altar "to an Unknown God." This gave him his opportunity, and he said, "I am going to tell you about this unknown God" (Acts 17:23). The message of the Gospel to the Chinese should be, "We want you to meet One who, through the centuries, you have been seeking."

B. In relation to the Chinese people, with a long cultural heritage of rich achievement, the Christian preaching should be conducted with respect and appreciation: respect for the unique and precious characteristics of the heritage, appreciation for the distinctive qualities of the Chinese temperament and point of view which the heritage has produced. 
1. Chinese are proud of their ancient culture.

In the Chinese we see a practical-minded people, a people who have made successful use of humanized social habits for the ordering of their lives, a people of amazing common sense, one whose ideal is the "way of the mean," between extremes.

2. Education has always been highly regarded.

The form of manner, the etiquette of human relations, is a matter of vital and moral importance. Chinese have learned courtesy from the race habits which Confucius established.

3. The country folk are generally inclined to be friendly and eager to live on what is most useful and least expensive. They still live a simple life, dominated for the most part by old traditions and superstitions. The products of the farms feed the nation. The life of the farmer is filled with superstitious fears. All material objects have within them a presiding spirit. The whole universe has been peopled by spirits and demons, and one must ex rcise himself by charms and prayers that may have the power to offset the dangers that constantly portend. While traditionally the farmer in China is placed second only to the scholar, in practice the plums of existence belong to the official, the scholar, and to the merchant the poor farmer getting the tail-end of mental and economic existence.

C. We should know what the people believe.

1. The names the Chinese call God.

a. Heaven--Not one person can get over Heaven. Heaven is above all people and is high and wide. People looked to heaven to protect them. Sonetimes calamities of fires and floods come, and men, not being able to stop it, have called Heaven "calamity." Fortune or misfortune, the rise and fall of nations, good crops or nothing--all have come, for the Chinese, from heaven. Confucius thought that all things he received depended upon his obeying heaven.

b. King--A great philosopher, Yangshih, said, "Heaven and King are the same." The King is ruler over heaven.

c. God--Confucius said, "We look for them but we do not see them, we 1isten to them, but do not hear them, yet they enter into all things and there is nothing without them. The Chinese thought of God as noble, powerful, and virtuous. 
2. Chinese worship and sacrifice.

a. Worship of heaven and earth--we read from Confucius, "By the ceremonies of the sacrifice to heaven and earth they served God."

b. Worship of mountain and river.

c. Worship of sun, moon and other things--They called the sun, moon, and stars in heaven, God. They had gods from the top of the heaven to the center of the earth. They could not be counted but each had evil and good influences for which the people thought they ought to show respect and dependence.

d. Worship of their ancestors--The Chinese, through filial piety have worshipped their ancestors from the very beginning until today. Confucius said, "They have three great parts of service for father and mother." This service is for the living, through the funeral, and for the worship of the temple. People have their own ancestoral temple for the worship of the dead.

e. Worship of saint, sage, patriot and hero--each generation has some saints, sages, patriots, and heroes, so each place builds a temple for them.

3. Meaning of Sacrifice.

The Classic of Filial Piety explains the Chinese character for sacrifice like this, "Sacrifice is an offering to God and the people commune with God." Here are some meanings for sacrifice.

a. God blesses the people and they make a sacrifice to show their gratitude to Him.

b. If a clamity comes to the people they make a sacrifice and ask God to let them escape this calamity.

c. The people offered a sacrifice to show their gratitude to the ancestors whose life and work benefited the people of the next generation.

d. The Spirit of the wicked brings calamity to the people and the people make a sacrifice to drive out the devil and to abolish him. 
D. The "Three Religions."

These major faiths have ministered on a large scale to China's spiritual needs and in these faiths much of China's deeper longings have been expressed.

1. Confucianism (Ju Chiao--religion of the scholar)

a. The ethical system based on the teachings of Confucius.

b. Confucianism is a lofty political and social system which has been successful in guiding the Chinese people through centuries of continuous life.

c. It looks upon life as a great and sacred stream into which we are born. The justification of our existence is determined by the contribution we make to that sacred stream.

d. Confucianism is opposed to the ideas of individualism.

2. Buddhism
a. Many Chinese find real spiritual uplift through Buddhist worship. They are seeking some means by which to win inward peace. They cultivate a spirit of contemplation by which to escape from the worries of Iife.
b. Buddhism is disinterested in society. The real world to them is pure spirit.

3. Taoism--the most superstitious of the forms of religion in China.
a. Magic practises and devil worship are closely associated with Taoist temples.

b. Devotees seek the elixir of life and immortality by alchemistic practi es and the whole series of methods.

V. Biblical Preaching and Chinese Culture.

A. We should seek with patient devotion to find contacts in indigenous Chinese religious teaching for the gospel of Jesus Christ and to interpret its message in a terminology more familiar to and better understood by the Chinese yearning hearts.

1. Familiar Buddhist phrases or Confucian phrases should be used through which to interpret the Christian message, so that it may be more readily understood and appreciated by the spiritual-minded of China. 
B. The biblical preacher should learn something more of the history and culture of the Chinese, of the great period of intellectual, administrative, literary, and religious development through which they have passed.

1. In philosophy, literature, art, and religion China has a record of great achievement.

C. Far too little is known by Christian preachers of the moral and religious psychology of the chinese. There is also very little understanding of the essential messages of the greater faiths of China. Study in this field will make it possible to relate the Christian message to the Chinese heart.

1. China's long training in family ethics under the inspiration of the great teacher Confucius should not be ignored.

2. There must be sincerity in biblical preaching. It will help the people to see Jesus in you.

3. If the world-wide Christian enterprise is to be more rapidly and more adequately successful, it must become filled more than ever before with Jesus' spirit of respect and love for man, a respect and love for nations as well as for individuals in our preaching. 
B I B L I O G R A P H Y 


\section{BIBLIOGRAPHY}

Abbey, Merrill R. Preaching to the Contemporary Mind. New York: Abingdon Press, 1963.

Allmen, Jean-Jacques von. Preaching and Congregation. Richmond, Virginia: John Knox Press, 1962.

Anderson, Roy Allan. Preachers of Righteousness. Nashville, Tennessee: Southern Publishing Association.

Barret, C. K. Biblical Problems and Biblical Preaching. Philadelphia: Fortress Press, 1964.

Barth, Karl. The Word of God and the Word of Man. New York: Harper and Row, 1957.

- The Preaching of the Gospe1, 1961. Translated by

B. E. Hooke. Philadelphia: The Westminister Press, 1963.

Bartlett, Gene E. The Audacity of Preaching. New York: Harper, 1962.

Baumann, J. Danie1. An Introduction of Contemporary Preaching. Grand Rapids, Michigan: Baker Book House, 1972.

Blackwood, Andrew W. Expository Preaching For Today. Nashville: Abingdon Press, 1953.

- Preaching From the Bible. New York: AbingdonCokesbury, 1941.

- The Preparation of Sermons. New York: AbingdonCokesbury Press, 1.948 .

Broadus, John A. On the Preparation and Delivery of Sermons. New York: Harper \& Brothers, 1944.

Brown, H. C., Jr. A Quest for Reformation in Preaching. Waco, Texas: Word Books, Pub., 1968.

, H. Gordon Clinard and Jesse J. Northcutt. Steps to the Sermon. Nashville: Broadman Press, 1963. 
Brunner, Emil. Revelation and Reason. Philadelphia: The Westminster Press, 1946.

Buttrick, George. Jesus Came Preaching. New York: Abingdon-Cokesbury Press, 1951.

- Sermons Preached in a University Church. New York: Abingdon Press, 1961.

Cleland, James T. Preaching To Be Understood. New York: Abingdon Press, 1965.

Clowney, Edmund P. Preaching and Biblical Theology. Grand Rapids, Michigan: Eerdmans, 1961.

Colquhoun, Frank. Christ's Ambassadors. Philadelphia: The Westminster Press, 1965.

Craddock, Fred B. As One Without Authority. Enid, Oklahoma: The Phillips University Press, 1971.

Criswe11, W. A. Why I Preach that the Bible is Literally True. Nashville: Broadman Press, 1969.

Davis, H. Grady. Design For Preaching. Philadelphia: Fortress Press, $195 \overline{8}$.

Dodd, C. H. The Authority of the Bible. Digswell place: James Nisbet and Co., Ltd., 1928.

- The Apostolic Preaching and Its Developments. London: Hodder S. Stoughton, Ltd., 1936.

Ebeling, Gerhard. Theology and Proclamation. Philadelphia: Fortress Press, 1966.

- Word and Faith. Philadelphia: Fortress Press, 1963.

Eckenroth, Melvin K. A Syllabus Study on Preaching the ChristCentered Message. Published by Department of Practical Theology. S.D.A. Theological Seminary. Washington, D.C.

Evans, Irwin Henry. The Preacher and His Preaching. Washington, D.C.: Review and Herald Publishing Association, 1938.

Evans, William. How to Prepare Sermons and Gospel Addresses. Chicago: Moody Press, n.d.

Farmer, H. H. The Servant of the Word. New York: Charles Scribner's Sons, 1942 .

Ford, D. W. C. Preaching Today. London: Epworth Press, 1969. 
Forsyth, P. T. Positive Preaching and the Modern Mind. Grand Rapids, Michigan: Eerdmans, 1964.

Garrison, Webb B. The Preacher and His Audience. New Jersey: Fleming H. Revell Co., 1954.

Grasso, Donemico S. J. Proclaiming God's Message. South Bend, Ind.: University of Notre Dame Press, 1965.

Hasilden, Kyle. The Urgency of Preaching. New York: Harper \& Row, 1963.

Hyde, Gordon M., ed. A Symposium on Biblical Hermeneutics. Washington, D.C.: The Review and Herald Publishing Association, 1974.

Jones, Ilion T. Principles and Practice of Preaching. New York: Abingdon Press, 1966.

Jordon, G. Ray. You Can Preach. New York: Fleming H. Revell, 1951.

Johnson, C. E. Biblical Preaching Today. Ann Arbor, Michigan: University Microfilms, A Xerox Comp., 1972.

Knox, John. The Integrity of Preaching. New York: Abingdon Press, 1957.

Koller, Charles W. Expository Preaching Without Notes. Grand Rapids, Michigan: Baker Book House, 1969.

Leibrecht, Walter, ed. Religion and Culture. New York: Harper, 1959.

Lenski, R. C. H. The Sermon: Its Homiletical Construction. Fort Worth, Texas: Potter's Book Store, 1927.

Littorin, Frank T. How to Preach the Word with Variety. Grand Rapids, Michigan: Baker Book House, 1953.

Luccock, Halford E. In the Minister's Workshop. Nashville, Tennessee: Abingdon-Cokesbury, 1944.

Malcomson, William L. The Preaching Event. Philadelphia: The Westminster Press, 1968.

Marcel, Pierre. The Relevance of Preaching. Grand Rapids, Michigan: Baker Book House, 1963.

Miller, Donald G. Fire in Thy Mouth. New York: Abingdon Press, 1954.

- The Way to Biblical Preaching. New York: Abingdon Press, 1957. 
Morgan, G. Campbe11. Preaching. New York: Fleming H. Reve11, 1937.

Moody, Dale. Spirit of the Living God. Philadelphia: Westminster Press, 1968 .

Perry, Lloyd M. Biblical Preaching for Today's World. Chicago: Moody Press, 1973.

- Biblical Sermon Guide. Grand Rapids, Michigan: Baker Book House, 1970.

- A Manual for Biblical Preaching. Grand Rapids, Michigan: Baker Book House, 1965 .

Ramm, Bernard. Protestant Biblical Interpretation: Grand Rapids, Michigan: Baker Book House, 1970.

Randolph, David James. The Renewal of Preaching. Philadelphia: Fortress Press, 1965.

Ray, Jefferson D. Expository Preaching. Grand Rapids, Michigan: Zondervan, 1940 .

Ritsch1, Dietrich. A Theology of Proclamation. Richmond, Virginia: John Knox Press, 1960.

Scherer, Paul. The Word God Sent. London: Hodder \& Stoughton, 1965.

Schloerb, Rolland $w$. The Preaching Ministry Today. New York: Harper \& Brothers Publishers, 1946.

Schroeder, Frederick W. Preaching the Word with Authority. Philadelphia: The Westminster Press, 1954.

Stevenson, Dwight E. In the Biblical Preacher's Workshop. Nashville, Tennessee: Abingdon Press, 1967.

- Preaching From the Books of the 01d Testament. New York: Harper \& Brothers Publishers, 1961.

- Preaching on the Books of the New Testament. New York: Harper \& Brothers Publishers, 1956.

Sleeth, Ronald E. Proclaiming the Word. Nashville: Abingdon, 1964.

Snyder, Russe11. Reality in Preaching. Philadelphia: Muhlenberg Press, 1942 .

Stewart, James S. A Faith to Proclaim. London: Charles Scribner's Sons, 1953. 

1942 .

Heralds of God. New York: Charles Scribner's Sons,

Tizard, L. J. Preaching. New York: Oxford University Press, 1959.

Toohey, William and Thompson, William D., eds. Recent Homiletical Thought. Nashville: Abingdon Press, 1967.

Turnbu11, Ralph G., ed. Baker's Dictionary of Practica1 Theology. Grand Rapids, Michigan: Baker Book House, 1967.

Unger, Merrill F. Principles of Expository Preaching. Grand Rapids, Michigan: Zondervan, 1955.

White, E. G. Desire of Ages. Mountain View, California: Pacific Press Publishing Association, 1940.

- Gospel Workers, Washington, D.C.: Review and Herald Publishing Association, 1936.

- Testimonies to Ministers. Mountain View, California: Pacific Press Publishing Association, 1944.

Whitesell, Faris D. The Art of Biblical Preaching. Grand Rapids, Michigan: Zondervan Publishing House, 1950.

- Power in Expository Preaching. New Jersey: Fleming H. Revel1, 1963.

and Lloyd M. Perry. Variety in Your Preaching. Westwood, New Jersey: Fleming H. Reve11 Co., 1954.

Wingren, Gustaf. The Living Word. Philadelphia: Muhlenberg Press, 1960. 